\title{
SAFETY ANALYSIS REPORT - PACKAGES \\ LP-50 TRITIUM PACKAGE \\ (Packaging of Fissile and Other Radioactive Materials)
}

\author{
FINAAL REPORT
}

$$
\text { April } 1975
$$

Compiled by
A. A. Gates

P. G. McCarthy

J. W. Edl

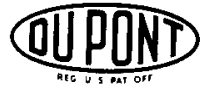

\section{E. 1. du Pont de Nemours and Company \\ Savannah River Plant \\ Aiken, South Carolina 29801}

\section{NOTICE}

\section{PORTIONS OF THIS REPORT ARE ItTEGTBLE. It has been roproduced fron tho best avallable copy to pernit the breadest possiblo avall- ab112ty.}

Prepared for the U.S. Energy Research and Development Administration under Contract AT(07-2)-1. 


\section{DISCLAIMER}

This report was prepared as an account of work sponsored by an agency of the United States Government. Neither the United States Government nor any agency Thereof, nor any of their employees, makes any warranty, express or implied, or assumes any legal liability or responsibility for the accuracy, completeness, or usefulness of any information, apparatus, product, or process disclosed, or represents that its use would not infringe privately owned rights. Reference herein to any specific commercial product, process, or service by trade name, trademark, manufacturer, or otherwise does not necessarily constitute or imply its endorsement, recommendation, or favoring by the United States Government or any agency thereof. The views and opinions of authors expressed herein do not necessarily state or reflect those of the United States Government or any agency thereof. 


\section{DISCLAIMER}

Portions of this document may be illegible in electronic image products. Images are produced from the best available original document. 


\section{CONTENTS}

Chapter

0.0 General Information

1.0 Structural Evaluation

2.0 Thermal Evaluation

3.0 Containment

4.0 Shielding Evaluation

5.0 Criticality Evaluation

6.0 Operating Procedures

7.0 Acceptance Tests and Maintenance Program

8.0 Quality Assurance Requirements

Figure

1 LP-50 Shipping Container Packaging - Assembly (Du Pont dwg S5-2-5733)

2 LP-50 Shipping Container Packaging - Insulation (Du Pont dwg S5-2-5734)

3A LP-50 Shipping Container Packaging - Detalls (Du Pont dwg S5-2-5735)

3B LP-50 Shipping Container Packaging - Bucket Cover (Du Pont dwg S4-2-596)

4 Flat-type Secondary Container (Research and Welding Company dwg 485-D-01)

5 LP-50 Transfer Container - Assembly \& Details (Du Pont dwg S5-2-186)

6 LP-50 Transfer Container - Details (Du Pont dwg S5-2-187)

7 Product Container Vacuum Tank Valve - Mark II (Ju Pont dwg S4-2-147)

8 First Fire Test - Effect of $30 \mathrm{ft}$ Drop on Side

9 First Fire Test - Effect of $40 \mathrm{in.} \mathrm{Drop} \mathrm{on} 6$ in. Piston

10 First Fire Test - Effect of Smoldering in Area of Vent Holes

11 First Fire Test - Unburned "Celotex" Away from Vents

12 First Fire Test - Effect of Smoldering on Bottom "Celotex" Disk Near Vent

13 Second Fire Test:= Effect of $30 \mathrm{ft}$ Drop on End of Drum and of Piston Drop

14 Second Fire Tes - View in Furnace During Test

15 Second Fire Test - -Effect of Smalderlng Near Vents

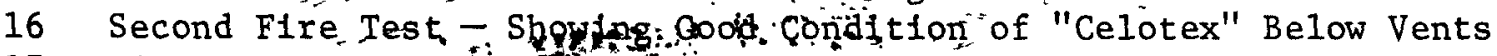

17 Fire Test Temperature

18 Aluminum Vessel Test Temperature

19 Four-Foot Drop on Bottom Edge

20 Four-Foot Drop on Top Edge

21 Thirty-Foot Drop at $15^{\circ}$ to Horizontal 
0.1 Introduction . . . . . . . . . . . . . . . . . . 0-1

0.2 Package Description . . . . . . . . . . . . . . . . . . . . . $0_{0-1}$

0.2 .1 Packaging ........................ $0-1$

0.2 .2 Operating Features ........................ . . . . . . $0-1$

0.2.3 Contents of Packaging . . . . . . . . . . . . . . . . . . $0-2$ 


\section{SAFETY ANALYSIS REPORT - PACKAGES \\ LP-50 TRITIUM PACKAGE}

\subsection{GENERAL INFORMATION}

$\underline{0.1 \text { Introduction }}$

Elemental tritium is shipped at low pressure in a stainless steel container (LP-50) sealed within an aluminum vessel and surrounded by Celotex ${ }^{(\dot{\beta})}$ insulation at least $4 \mathrm{in.} \mathrm{thick} \mathrm{in} \mathrm{a} \mathrm{steel} \mathrm{drum.}$

Each package contains a large quantity of nonfissile, Group VII material, as defined in ERDAM 0529, and complies with appropriate sections of that manual. No exemptions are claimed.

\subsection{Package Description}

\section{2 .1 Packaging}

The total weight of the package is 260 pounds maximum. The various components that constitute the package are shown in figures 1 through 7 and major components, i.e., drum, insulation, secondary container, and product (primary) container, are described in the following paragraphs.

The drum is fabricated from 16 gage carbon steel to the dimensions of 22.5 in. ID by $38.5 \mathrm{in.}$ inside height per Military Standard MS-27683 (or equa1). Three $5 / 16$ in. dia holes are drilled, approximately $120^{\circ}$ apart, one in. below the top curl of the body and are covered on both sides with lead tape. The holes prevent rupture of the drum during a fire by venting the gases from the insulation. A locking ring with dropped forged lugs, installed with a $3 / 8$ in. highstrength steel bolt, provides closure by securing the cover to the drum.

The insulation that cradles the secondary container, also called aluminum shell, within the drum is Celotex ${ }^{\circledR}$, laminated military packing board per Military Specification Mi1-F-26862-A, except paragraph 3.7 concerning fungus resistance. When the Celotex, supplied in minimum thickness of $1-1 / 2$ in. is fabricated and coated with Cera-kote $\AA^{2}\left(120 \mathrm{ft}^{2}, 0.010 \mathrm{in}\right.$. thick, per gal unthinned high temperature cement), the annular pieces form a 14-1/4 in. ID void within the drum which symetrically positions the shell. A top outer ring of molded Cera Form ${ }^{3}$ is cemented with Cera-kote ${ }^{\circledR}$ to the adjacent rings of Celotex ${ }^{\circledR}$ to form a refractory barrier behind the drilled vent holes in the drum. A disk of Cerafelt $\AA^{4}$ is used as a spacer to restrict the movement of the Celotex® within the drum.

The shell, contained by the insulation, is a two-piece container of cast aluminum alloy, type 356, which houses the primary tritium (product) container (PC). Two cover designs (figure 1) exist: one flat and the other domed. The bottom part of the container is 26-5/16 in. inside depth by 13-1/2 in. ID. The side wall and bottom are nominally 15/64 in. thick. A flange of 16-1/4 in. OD on the bottom section provides attachment to the mating flange on the top section (cover). Either cover, flat or domed, is secured to the bottom part by bolts equally spaced on a 15-1/2 in. dia bolt circle with a buna $N$ gasket compressed between the flanges. Two handles are provided for ease of handling.

1 Celotex Corp. trademark.

2,3,4 Johns Manville Corp. trademarks.

$$
-0-1-
$$


The type 347 stainless steel PC, of welded construction, is essentially a closed cylinder with a 13 in. ID and $0.078 \mathrm{in.} \mathrm{wal1} \mathrm{thickness,} \mathrm{with} \mathrm{radiused}$ top and bottom edges. Complete closure of the cylinder is accomplished by welding on a container cover (head top) to which the fill tube and primary seal (vacuum tank valve) are attached.

The PC is held in position by close fit with the shell and by a laminated plywood spacer with neoprene pads that is held between the top of the PC and the shell cover. This method of positioning provides both axial and transverse support and restricts movement of the PC within the sheil during transport.

Filling the PC through the valve is accomplished by attaching the supply source to a continuation of the stainless steel tubing which has a compression type connection. The overall length of the container, including the blind compression nut that covers the open end during shipment, is approximately 28-1/4 in.

\title{
0.2 .2 Operating Features
}

The operational features of the LP-50 package are described in chapter 6.0, Operating Procedures.

\section{2 .3 Contents of Packaging}

Tritium gas may be pure or may contain varying amounts of protium (hydrogen-1), deuterium, or helium. The following restrictions apply to the use of this container:

\author{
Maximum tritium content \\ $75,300 \operatorname{STP}$ cc $(193,500$ curies $)$ \\ Radioactive decay heat \\ $22.4 \mathrm{Btu} / \mathrm{hr}$ \\ Maximum total pressure in \\ primary container as \\ loaded \\ $24.2 \mathrm{psia}\left(1250\right.$ torrs) at $25^{\circ} \mathrm{C}$
}




\subsection{STRUCTURAL EVALUATION}

1.1 Structural Design . . . . . . . . . . . . . . . . . . 1-1

1.1 .1 Discussion . . . . . . . . . . . . . . . . . 1-1

1.1.2 Design Criteria . . . . . . . . . . . . . . . 1-1

1.2 Weights . . . . . . . . . . . . . . . . . . . 1-2

1.3 Mechanical Properties of Materials . . . . . . . . . . . . 1-3

1.4 General Standards for all Packages . . . . . . . . . . . . . 1-4

1.4.1 Chemical and Galvanic Reactions ............. . 1-4

1.4.2 Positive Closure................... . 1-5

1.4.3 Lifting Devices .................... . . 1-5

1.4.4 Tiedown Devices .................. . . 1-5

1.5 Standards for Type B and Large Quantity Packaging . . . . . . . 1-5

1.5.1 Load Resistance . . . . . . . . . . . . . . . . 1-5

1.5.2 External Pressure of 25 psig . . . . . . . . . . . 1-5

1.6 Normal Conditions of Transport . . . . . . . . . . . . . 1-12

1.6.1 Heat........................ 1-12

1.6 .2 Cold . . . . . . . . . . . . . . . . . . 1-12

1.6.3 Pressure....................... . . 1-13

1.6.4 Vibration ..................... . . 1-19

1.6.5 Water Spray ................... . 1-19

1.6 .6 Free Drop . . . . . . . . . . . . . . . . . . 1-19

1.6 .7 Corner Drop . . . . . . . . . . . . . . . . . . 1-19

1.6.8 Penetration ................... . . 1-20

1.6 .9 Compression ..................... 1-20

1.7 Hypothetical Accident Conditions . . . . . . . . . . . . 1-20

1.7.1 Free Drop ...................... . 1-20

1.7 .2 Puncture ..................... $1-20$

1.7 .3 Thermal ...................... $1-20$

1.7 .4 Water Immersion ..................... 1-21

1.7.5 Summary of Damage .................. . . 1-21

1.8 Special Form . . . . . . . . . . . . . . . . . . 1-22

1.9 Fuel Rods........................ . . . 1-22 


\subsection{STRUCTURAL EVALUATION}

1.1 Structura1 Design

\subsubsection{Discussion}

The principal structural members of the LP-50 are the stainless steel product container ( $P C)$, the aluminum inner container (shel1), the plywood spacer between the PC and the shell, the Celotex ${ }^{\circledR}$ insulation, and the carbon steel drum. The PC has a specially fabricated stainless steel valve that is used for loading and the shell has a valve used for leak testing. There are two types of covers for the shell - flat and hemispherical (domed). There are also matching spacers to provide a tight fit between the PC and the shell. The shell fits snugly into the cemented rings of Celotex ${ }^{\circledR}$ insulation. There is a clearance of only $1 / 8$ in. between the Celotex ${ }^{\circledR}$ and the drum. No gasket is used with the locking ring and it is equipped with drop-forged lugs and a special bolt to fasten the cover securely. A drum, made to military specifications (with some modifications), completes the packaging.

\subsubsection{Design Criteria}

The following tables proyide a comparison of the ASME Boiler and Pressure Vessel Code values for maximum allowable stress and the calculated values.

Table 1. Stress Comparison

(0.5 atmos external pressure)

\begin{tabular}{|c|c|c|c|}
\hline \multirow{2}{*}{ Part } & \multicolumn{2}{|c|}{ Maximum Allowable Stress, psi } & \multirow{2}{*}{$\mathrm{CaI} / \mathrm{ASME}, \%$} \\
\hline & ASME & & \\
\hline She11: side & 6200 & 300 & 5 \\
\hline bottom & 6200 & 5520 & 89 \\
\hline top & 9500 & 5840 & 61 \\
\hline Bolt & 20,000 & 14,050 & 72 \\
\hline Flange hub & 9300 & 3450 & 37 \\
\hline $\begin{array}{l}\text { (Gasket } \\
\text { seating) }\end{array}$ & & & \\
\hline radial & 6200 & 1010 & 16 \\
\hline tangential & 6200 & 590 & 10 \\
\hline Flange hub & 9300 & 2730 & 29 \\
\hline $\begin{array}{l}\text { (Operating } \\
\text { condition) }\end{array}$ & & & \\
\hline radial & 6200 & 801 & 13 \\
\hline tangential & 6200 & 322 & 5 \\
\hline
\end{tabular}


Table 2. Pressure Comparison

(25 psig external pressure)

Maximum Allowable Press.,, psig

\begin{tabular}{lccc} 
Part & Test & Calc (1.5.2) & Test/Calc, \% \\
\hline Shell (flat cover) & 25 & 123 & 20 \\
Bottom head & 25 & 33 & 76 \\
Top head & 25 & 35 & 71 \\
Shel1 (dome cover) & 25 & 167 & 15 \\
& ASME & Calc & Calc/ASME, \% \\
Flange (flat cover) hub & 9300 & 2443 & 26 \\
(Gasket seating) & & & 12 \\
radial & 6200 & 289 & 5 \\
tangential & 6200 & &
\end{tabular}

\subsection{Weights}

Weights of the components of the LP-50 packaging are:

Product container

$\frac{W t, 1 b}{32}$

Wooden spacer

9

Secondary container

43

Insulation

104

Drum

72

Total

260 


\subsection{Mechanical Properties of Materials}

Information referenced in the American Society of Mechanical Engineers Boiler and Pressure Vessel Code, section VIII, div 1, 1974 edition are abbreviated "ASME, p ."

1. $\mathrm{B}=7400 ;$ ASME, $\mathrm{p} 280$, figure UNF-28.5.

2. $\mathrm{C}$ (bottom head) $=0.3$; ASME, p 25, figure UG-34 (b-2). $C($ top head $)=0.2 ;$ ASME, p 25, figure UG-34 (d).

3. $\mathrm{S}$ (bottom head) $=18,000$ psi; ASME, p 149, min yield for SB-26 SG 70A-T71. $\mathrm{S}($ top head) $=20,000$ psi ASME, p 149, min yield for 356-T6.

4. $m=0.50$ for elastomers below 75 Shore Durometer; ASME, p 238, table UA49.1.

5. $y=0.0$ psi for elastomers below 75 Shore Durometer; ASME, p 238, table $\mathrm{UA}-49.1$.

6. $\mathrm{K}=\frac{\mathrm{OD}}{\mathrm{ID}} \quad \frac{16.25}{13.5}=1.20$; ASME, p 240, figure UA-51.1, $\mathrm{T}=1.84, \mathrm{U}=11.81, \mathrm{Y}=10.75$, and $\mathrm{Z}=5.55$.

7. $f=1.0$; ASME, $p 242$, figure UA-51.6 (when $g_{1} / g_{0}=1.0$ and $h / h_{0}=0.164$ ).

8. $F=0.909$; ASME, $p 240$, figure UA-51.2 (when $g_{1} / g_{0}=1.0$ and $\left.h / h=0.164\right)$.

9. $V=0.55$; ASME, p 241, figure UA-51.3 (when $g_{1} / g_{0}=1.0$ and $h / h_{0}=0.164$ ).

10. Allowable stress for SB-26 SG70A(356)-T71 is 6200 psi; ASME, p 149 .

11. $\mathrm{B}=5500$ psi; ASME, p 278, UNF 28.3.

12. Allowable tensile stress for type $6061-\mathrm{T} 6$ aluminum at $200^{\circ} \mathrm{F}=9500$ psi and at $250^{\circ} \mathrm{F}=9100$ psi; ASME, p 149, table UNF-23.1.

13. Allowable tensile stress for SB-26 SG-70A(356)-T71 up to $200^{\circ} \mathrm{F}=6200$ psi; ASME, p 149, table UNF-23.1.

14. $\mathrm{E}=1.0 ;$ ASME, $\mathrm{p} 14$, UG-27.

15. Max allowable bolt stress (S) is 20,000 psi; ASME, p 127, table UCS-23.

16. Area of $1 / 4$ in. is 0.0269; Mechanical Engineers Handbook, L. S. Marks, 5 th Ed, p 862 . 


\subsection{General Standards for all Packages}

\subsubsection{Chemical and Galvanic Reactions}

There is no reaction between the packaging and contents. However, some tritium can permeate through the wall of the product container (see chapter 3.0, Containment). Also, there will be no significant reaction between any of the parts of the packaging. The following chart shows what dissimilar materials are in contact $(\mathrm{X})$.

\begin{tabular}{|c|c|c|c|c|c|c|c|c|c|c|c|c|c|c|}
\hline 1 & Aluminum & - & & $\mathrm{X}$ & $\mathrm{X}$ & $\mathrm{X}$ & & & $\mathrm{X}$ & $\mathrm{X}$ & & $\mathrm{x}$ & & $\mathrm{X}$ \\
\hline 2 & Brass & & - & & & & & & $\mathrm{X}$ & $\mathrm{X}$ & & $\mathrm{x}$ & & \\
\hline 3 & Buna N & $\mathrm{X}$ & & - & & & & & $\mathrm{X}$ & & & & & \\
\hline 4 & Celotex ${ }^{\circledR}$ & $\mathrm{X}$ & & & - & & $\mathrm{x}$ & & $\mathrm{X}$ & & $\mathrm{x}$ & & $\mathrm{x}$ & $\mathrm{X}$ \\
\hline 5 & Neoprene & $\mathrm{X}$ & & & & - & & & $\mathrm{X}$ & & & & $\mathrm{x}$ & \\
\hline 6 & Nylon & & & & $\mathrm{X}$ & & - & & $\mathrm{X}$ & & $\mathrm{x}$ & & $\mathrm{X}$ & \\
\hline 7 & Paint & & & & & & & - & $\mathrm{X}$ & & & $\mathrm{X}$ & & $\mathrm{X}$ \\
\hline 8 & Steel & $\mathrm{X}$ & $\mathrm{X}$ & $\mathrm{X}$ & $\mathrm{X}$ & $\mathrm{x}$ & $\mathrm{x}$ & $\mathrm{x}$ & - & $\mathrm{x}$ & $\mathrm{X}$ & $\mathrm{x}$ & $\mathrm{x}$ & $\mathrm{X}$ \\
\hline 9 & Viton ${ }^{\circledR}$ & $\mathrm{X}$ & $\mathrm{X}$ & & & & & & $\mathrm{X}$ & - & & & & \\
\hline 10 & Weldwood glue & & & & $\mathrm{X}$ & & $\mathrm{X}$ & & $\mathrm{X}$ & & - & & $\mathrm{X}$ & \\
\hline 11 & Wire seal (lead) & $\mathrm{X}$ & $\mathrm{X}$ & & & & & $\mathrm{X}$ & $\mathrm{X}$ & & & - & & $\mathrm{X}$ \\
\hline 12 & Wood & & & & $\mathrm{X}$ & $\mathrm{X}$ & $\mathrm{X}$ & & $\mathrm{X}$ & & $\mathrm{X}$ & & - & \\
\hline 13 & Zinc or cadmium & $\mathrm{X}$ & & & $\mathrm{X}$ & & & $\mathrm{X}$ & $\mathrm{X}$ & & & $\mathrm{X}$ & & - \\
\hline
\end{tabular}




\subsubsection{Positive Closure}

The closure system is made up of three parts; the package cannot be opened inadvertently. The parts of the system are:

- The valve and its compression cap on the PC which are secured with a leaded wire seal.

- The shell flange which is secured with bolts (two bolts are also secured with leaded wire seals), and the shell vent valve which is secured with a nipple cap and a leaded wire seal.

- The drum lid which is fastened to the drum with a bolted locking ring. The lugs on the locking ring are secured with a leaded wire seal.

\subsubsection{Lifting Devices}

Not applicable. There is no lifting device on the drum.

\subsubsection{Tiedown Devices}

Not applicable. There is no tiedown device on the drum.

\subsection{Standards for Type $B$ and Large Quantity Packaging}

\subsubsection{Load Resistance}

Tests showed that the LP-50 drum could support a uniformly distributed load along its major axis equal to five times its loaded weight.

Bags of lead shot were stacked uniformly from bottom to top against one side of an upright empty LP-50 drum. The lid was installed and the drum was carefully laid over on its side and brought to rest with only the rim at each extreme end in contact with supporting timbers. No deformation or damage resulted.

\subsubsection{External Pressure of 25 psig}

External pressure will affect only the aluminum shell.

- Shell with flat cover. Material of shell and bottom head is type 356 aluminum alloy. However, mechanical specifications for SB-26-SG70A-T71 will be used. Allowable stresses are listed in ASME Code. 
Reference for equations is ASME Code, section VIII, div 1, page No. as noted.
$P_{a}=\frac{B}{D_{0} / t}$
p 16, UG-28
$t=\mathrm{d} \sqrt{\mathrm{CP} / \mathrm{S}} \quad$ or $\mathrm{P}=\frac{\mathrm{S}}{\mathrm{C}}\left(\frac{\mathrm{t}}{\mathrm{d}}\right)^{2}$
p 24, UG-34

where:

$\mathrm{L}=$ design length of vessel section, in.

$\mathrm{B}=$ factor depending on $\mathrm{D}_{\mathrm{o}} / \mathrm{t}$ and $\mathrm{P}_{\mathrm{a}}$ (dimensionless)

$D_{0}=$ OD of cylindrical she11, in.

$\mathrm{P}_{\mathrm{a}}=\max$ allowable working press., psi

$t=$ min required thickness of cylindrical shell on flat head, in.

$\mathrm{C}$ = factor depending on method of head attachment (dimensionless) (see 1.3, item 2)

$\mathrm{d}=$ dia or short span as in UG-34, in.

$\mathrm{P}=$ design press., psi

S - max allowable stress (see 1.3, item 3)

- She11

$\frac{\mathrm{L}}{\mathrm{D}_{\mathrm{O}}}=\frac{26.75}{14}=1.91, \frac{\mathrm{D}_{\mathrm{O}}}{\mathrm{t}}=\frac{14}{0.234}=60$

$\therefore B=7400 \quad($ see 1.3 , item 1$)$

$\mathrm{P}_{\mathrm{a}}=\frac{\mathrm{B}}{\mathrm{D}_{\mathrm{O}} / \mathrm{t}}=\frac{7400}{60}=123$ psig greater than $25 \quad \underline{\mathrm{OK}}$

- Bottom Head

$P=\frac{S}{C}\left(\frac{t}{d}\right)^{2}=\frac{18,000}{0.3} \quad \frac{0.312}{13.25}^{2}=33.3 \mathrm{psig}$

greater than 25

$\underline{\mathrm{OK}}$ 
- Top Head

$P=\frac{S}{C}\left(\frac{t}{d}\right)^{2}=\frac{20,000}{0.2}\left(\frac{0.25}{13.375}\right)^{2}=35$ psig

greater than 25

$\underline{\mathrm{OK}}$

- Flange and Bolting

$$
\begin{aligned}
& \mathrm{W}_{\mathrm{m}_{2}}=\pi \mathrm{b} \mathrm{G} \mathrm{y} \\
& \text { P 243, UA-49 } \\
& \mathrm{A}_{\mathrm{m}_{2}}=\mathrm{W}_{\mathrm{m}_{2}} / \mathrm{s}_{\mathrm{a}} \\
& \text { p 234, UA-47 } \\
& \mathrm{W}=1 / 2\left(\mathrm{~A}_{\mathrm{m}_{2}}+\mathrm{A}_{\mathrm{b}}\right) \mathrm{S}_{\mathrm{a}} \\
& \text { p 243, UA-49 } \\
& \mathrm{M}_{\mathrm{O}}=\mathrm{Wh}_{\mathrm{G}} \\
& \text { p 243, UA-50 } \\
& M_{0}=H_{D}\left(h_{D}-h_{G}\right)+H_{T}\left(h_{T}-h_{G}\right) \\
& \text { p 245, UA-55 }
\end{aligned}
$$

where:

$$
\begin{aligned}
& \mathrm{W}_{\mathrm{m}_{2}}=\text { min required bolt load for gasket seating, } 1 \mathrm{~b} \\
& \mathrm{~b}=\text { effective gasket seating width (0.25 in.) } \\
& \mathrm{G}=\text { mean dia of gasket contact face (14.25 in.) } \\
& \mathrm{y}=\text { gasket unit seating load }(0.01 \mathrm{~b}) \text { (see } 1.3 \text {, item 5) } \\
& \mathrm{S}_{\mathrm{a}}=\text { allowable bolt stress at atmospheric temp, psi } \\
& \begin{aligned}
\mathrm{A}_{2}= & \text { total cross-sectional area of bolts at section of least diameter } \\
& \text { required for seating, in }{ }^{2}
\end{aligned} \\
& \mathrm{~W}=\text { flange design bolt load, } 1 \mathrm{~b} \\
& \mathrm{~A}_{\mathrm{b}}=\text { cross-sectional area of bolts using root diameter of thread, in }{ }^{2} \\
& \mathrm{M}_{\mathrm{O}}=\text { total moment acting upon flange, in.-1b } \\
& \text { h }=\text { hub length, in. } \\
& H_{D}=\text { hydrostatic end force on area inside of flange } \\
& =\begin{array}{l}
0.785 \mathrm{~B}^{2} \mathrm{P} \\
\text { pressure })
\end{array} \quad(\mathrm{B}=\mathrm{ID} \text { of flange, } 13.5 \mathrm{in} ., \text { and } \mathrm{P} \text { is } 25 \mathrm{psig} \text { test } \\
& h_{D}=\text { radial distance from bolt circle to circle on which } H_{D} \text { acts, in. }
\end{aligned}
$$




$$
\begin{aligned}
& \mathrm{H}_{\mathrm{T}}=\begin{array}{l}
\text { difference between total hydrostatic end force and hydrostatic } \\
\text { end force on area inside of flange, } 1 \mathrm{~b}=\mathrm{H}-\mathrm{H}_{\mathrm{D}}
\end{array} \\
& \mathrm{H}=\text { total hydrostatic end force, } 1 \mathrm{~b}=0.785 \mathrm{G}^{2} \mathrm{P} \\
& \mathrm{h}_{\mathrm{T}}=\text { radial distance from bolt circle to circle on which } \mathrm{H}_{\mathrm{T}} \text { acts, in. } \\
& \mathrm{h}_{\mathrm{G}}=\text { radial distance from gasket load reaction to bolt circle, in. } \\
& \mathrm{W}_{\mathrm{m}_{2}}=\pi \mathrm{b} \mathrm{G}=\pi(0.25)(14.25)(0.0)=0.01 \mathrm{~b} \\
& \mathrm{~A}_{\mathrm{m}_{2}}=0.0 \mathrm{in}^{2}=0.215 \mathrm{in}^{2} \\
& \left.\mathrm{~A}_{\mathrm{b}}=8(0.0269)=0.215\right)(20,000)=21501 \mathrm{~b} \\
& \mathrm{~W}=1 / 2\left(\mathrm{~A}_{2}+\mathrm{A}_{\mathrm{b}}\right) \mathrm{S}_{\mathrm{a}}=1 / 2(0.0+0.001
\end{aligned}
$$$$
\text { (from page 243, table UA-50) }
$$$$
h_{G}=\frac{C-G}{2}, h_{T}=\frac{R+g_{I}+h_{G}}{2} \text {, and } h_{D}=R+0.5 g_{I} \text {. }
$$

where:

$$
\begin{aligned}
& \mathrm{C}=\text { bolt circle dia (15.5 in.) } \\
& \mathrm{R}=\frac{\mathrm{C}-\mathrm{B}}{2}-\mathrm{g}_{1}, \\
& \mathrm{~g}_{1}=\text { thickness of hub at back of flange }(0.234 \mathrm{in.}) \\
& \mathrm{h}_{\mathrm{G}}=\frac{\mathrm{C}-\mathrm{G}}{2}=\frac{15.50-14.25}{2}=\frac{1.25}{2}=0.625 \mathrm{in} . \\
& \mathrm{h}_{\mathrm{T}}=\frac{\mathrm{R}+\mathrm{g}_{1}+\mathrm{h}_{\mathrm{G}}}{2}=\frac{0.766+0.234+0.625}{2}=0.812 \mathrm{in} . \\
& \mathrm{R}=\frac{\mathrm{C}-\mathrm{B}}{2}-\mathrm{g}_{1}=\frac{15.5-13.5}{2}-0.234 \\
& \mathrm{~h}_{\mathrm{D}}=\mathrm{R}+0.5 \mathrm{~g}_{1}=0.766+0.5(0.234)=0.883 \mathrm{in} \text {. } \\
& \mathrm{M}_{\mathrm{O}}=\mathrm{Wh}=2150(0.625)=1340 \mathrm{in.}-1 \mathrm{~b} \text { (gasket seating) }
\end{aligned}
$$




$$
\begin{aligned}
\mathrm{H}_{\mathrm{T}} & =\mathrm{H}-\mathrm{H}_{\mathrm{D}}=0.785 \mathrm{G}^{2} \mathrm{P}-0.785 \mathrm{~B}^{2} \mathrm{P}=\left(0.785 \mathrm{G}^{2}-\mathrm{B}^{2}\right) \mathrm{P} \\
\mathrm{MO}_{\mathrm{O}} & =\mathrm{H}_{\mathrm{D}}\left(\mathrm{h}_{\mathrm{D}}-\mathrm{h}_{\mathrm{G}}\right)+\mathrm{H}_{\mathrm{T}}\left(\mathrm{h}_{\mathrm{T}}-\mathrm{h}_{\mathrm{G}}\right) \\
\therefore \mathrm{M}_{\mathrm{O}} & =(0.785) \mathrm{B}^{2} \mathrm{P}(0.883-0.625)+(0.785)\left(\mathrm{G}^{2}-\mathrm{B}^{2}\right)(\mathrm{P})(0.812-0.625) \\
& =(0.785)(13.5)^{2}(25)(0.258)+(0.785)\left(14.25^{2}-13.5^{2}\right)(25)(0.187) \\
& =923+76=999 \text { in. }-1 \mathrm{~b} \text { (operating conditions) }
\end{aligned}
$$

Gasket seating monent of $1340 \mathrm{in.-1b}$ is larger and governs.

Bolt stress $=\frac{2150}{0.215}=10,000 \mathrm{psi}$

Flange stresses (flat top):

$$
\begin{aligned}
S_{H}=\frac{f M_{O}}{L\left(g_{1}\right)^{2} B} & \text { p 244, UA-51 } \\
S_{R}=\frac{(1.33 t e+I) M_{O}}{L t^{2} B} & \text { p 244, UA-51 } \\
S_{T}=\frac{Y M_{O}-Z S_{R}}{t^{2} B} & \text { p 244, UA-51 }
\end{aligned}
$$

where:

$\mathrm{S}_{\mathrm{H}}=$ calculated longitudinal stress in hub, psi

$S_{R}=$ calculated radial stress in flange, psi

$\mathrm{S}_{\mathrm{T}}=$ calculated tangential stress in flange, psi

$\mathrm{f}=$ hub stress correction factor (a function of $g_{1} / g_{0}$ and $h / h_{0}$ )

$g_{1}=$ thickness of hub at back of flange, in.

$g_{0}=$ thickness of hub at small end, in.

h $=$ hub length, in.

$h_{0}=$ factor $=\sqrt{B g_{0}}$, in.

$B=$ ID of flange, in. 


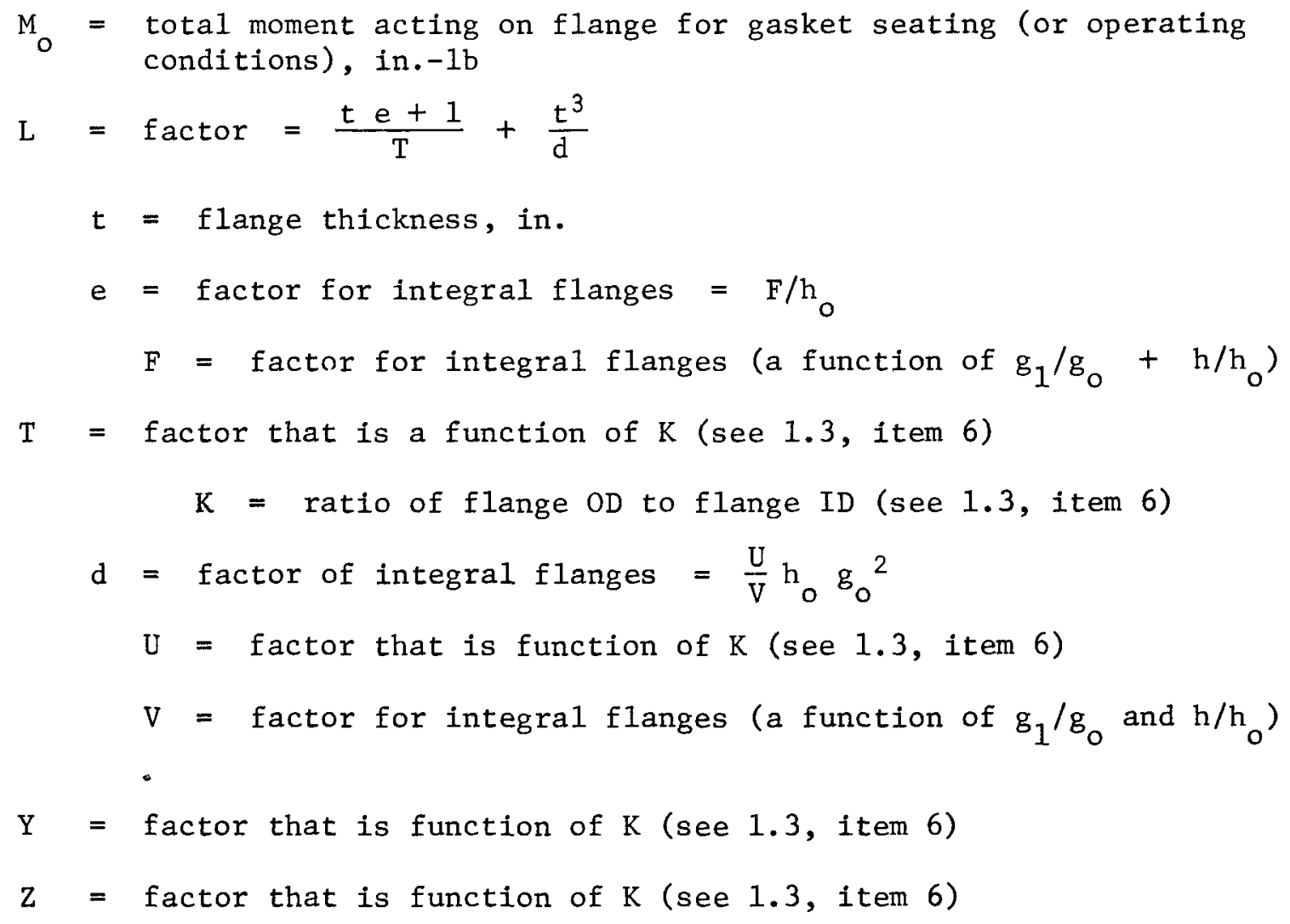

Flange factors:

$$
\begin{aligned}
& \mathrm{f}=\mathrm{g}_{1} / \mathrm{g}_{\mathrm{O}}=\frac{0.234}{0.234}=1.0 \\
& \mathrm{~h} / \mathrm{h}_{\mathrm{O}}=\frac{\mathrm{h}}{\sqrt{\mathrm{B} \mathrm{g}_{\mathrm{O}}}}=\frac{0.292}{\sqrt{13.5(0.234)}}=\frac{0.292}{1.78}=0.164 \\
& \mathrm{f} \quad=1.0(\text { see } 1.3 \text {, item } 7) \\
& \mathrm{e}=\mathrm{F} / \mathrm{h}_{\mathrm{O}}=\frac{0.909}{1.78}=0.511 \text { (for F, see } 1.3 \text {, item 8) } \\
& \mathrm{d}=\frac{\mathrm{U}}{\mathrm{V}} \mathrm{h}_{\mathrm{O}} \mathrm{g}_{\mathrm{O}}{ }^{2}=\frac{11.81}{0.55}(1.78)(0.234)^{2}=2.1 \\
& \text { (for } \mathrm{T}, \mathrm{U}, \mathrm{Y} \& \mathrm{Z} \text {, see } 1.3 \text {, item 6) } \\
& \text { (for } \mathrm{V}, \text { see } 1.3 \text {, item 9) }
\end{aligned}
$$




$$
\begin{aligned}
L=\frac{t e+1}{T}+\frac{t^{3}}{d} & =\frac{0.5(0.511)+1}{1.84}+\frac{(0.5)^{3}}{2.1} \\
& =0.682+0.060=0.742
\end{aligned}
$$

$$
\mathrm{S}_{\mathrm{H}}=\frac{\mathrm{fM}}{\mathrm{L}\left(g_{1}\right)^{2} \mathrm{~B}}=\frac{1.0(1340)}{0.742(0.234)^{2}(13.5)}=2443 \text { psi less than } 1.5(6200) \text { } \underline{\mathrm{CK}}
$$

(see 1.3 , item 10)

$$
S_{R}=\frac{(1.33 t e+1) M_{0}}{L t^{2} B}=\frac{[(1.33)(0.5)(0.511)+1] 1340}{(0.742)(0.5)^{2}(13.5)}
$$

$$
=717 \text { psi less than } 6200
$$

$$
\begin{aligned}
S_{T} & =\frac{Y M_{O}}{t^{2} B}-Z_{R}=\frac{10.75(1340)}{(0.5)^{2}(13.5)}-5.55(717) \\
& =4268-3979=289 \text { psi less than } 6200
\end{aligned}
$$

Conclusion: The flat type shell will withstand 25 psig external pressure; therefore, the inner product container should be unaffected.

- Shel1 with Domed Cover

Yield pressure (P) of cover (figure 6,E)

$$
P_{a}=\frac{B}{L_{1} / t_{h}}
$$

where:

$\mathrm{P}_{\mathrm{a}}=\max$ allowable working press., psi

$\mathrm{L}_{1}=$ inside radius of hemispherical head, in.

$t=$ min required thickness of head, in.

$\mathrm{B}=$ calculated compressive stress, psi 


$$
\begin{aligned}
& \text { from } \mathrm{L}_{1} / \mathrm{t}_{\mathrm{h}}=\frac{8.25}{0.25}=33 \text {, and } \frac{\mathrm{L}_{1}}{100 \mathrm{t}_{\mathrm{h}}}=0.33 \\
& \mathrm{~B}=5500 \mathrm{psi} \text { (see 1.3, item 11) } \\
& \text { Since } \mathrm{B}=5500 \text { and is less than } 9100 \text { (see 1.3, item 12) } \\
& \text { Allowable externa1 pressure }=\mathrm{P}_{\mathrm{a}}=\frac{\mathrm{B}}{\mathrm{L}_{1} / \mathrm{t}}=\frac{5500}{33}=167 \text { psid }
\end{aligned}
$$

Since this is greater than the specified differential pressure of 25 psid, the hemispherical head can withstand the given test pressure (25 psid) with no damage.

\subsection{Normal Conditions of Transport}

$\underline{1.6 .1 ~ H e a t ~}$

1.6.1.1 Summary of Pressures and Temperatures

See 2.1.1.

1.6.1.2 Differential Thermal Expansion

Hypothetical accident condition tests did not cause any damage attributable to differential thermal expansion (see 1.7.3.2). Conditions of normal transport are much less severe, thus no problems will be encountered during "normal transport" or actual transport conditions.

\subsubsection{Stress Calculations}

Repeated shipments (with attendant thermal cycles) have produced no degrading effects on the packaging. Deformation of the product container is checked during unloading operations per DPSOL 232-H-813.

\subsubsection{Comparison with Allowable Stresses}

See table in subsection 1.1.2.

\section{$\underline{1.6 .2 \operatorname{Cold}}$}

This package contains no liquids or other material harmfully affected by an ambient temperature of $-40^{\circ} \mathrm{F}\left(-40^{\circ} \mathrm{C}\right)$. The shel1 temperature when ambient temperature is $100^{\circ} \mathrm{F}$ (in shade is $100.4+18.9=119.3$ or $\approx 120^{\circ} \mathrm{F}(2.5 .3)$. When ambient temperature is $-40^{\circ} \mathrm{F}$ or $[100-(40)]$ lower, the shell temperature would be $\approx 120-140=-20^{\circ} \mathrm{F}$. The yield strength of the aluminum shell would be higher at this temperature than at the higher temperatures of normal conditions. 
Also, the $-20^{\circ} \mathrm{F}$ is within the design range for the gasket materials: buna $\mathrm{N}$, and Viton ${ }^{1}$

\subsubsection{Pressure $(0.5$ atmosphere)}

It is shown under 2.4.4 that the maximum internal pressure in the secondary container (she11) is 17.5 psia. With 0.5 standard atmospheric pressure on the outside of the shell, the differential across the wall is

$$
\mathrm{P}=17.5-0.5(14.7)=10.2 \mathrm{psig} \text { and the temperature is } 180^{\circ} \mathrm{F} \text {. }
$$

Since allowable stresses for type 356-T51 aluminum are not listed in the ASME Code, the stresses for the similar type SB-26 SG-70A (356)-T71 will be used (see 1.3, item 13).

Allowable stress at $180^{\circ} \mathrm{F}$ is $6200 \mathrm{psi}$.

Shell stresses: $\mathrm{P}=10.2$ psig.

This equation is from ASME Code, section VIII, div 1, p 14, UG-27, (c), (1).

$$
\text { She11: } S=\frac{P(R+0.6 t)}{E t} \text { or } t=\frac{P R}{S E-0.6 P}
$$

where:

$S=\max$ allowable stress, psi

$\mathrm{P}=$ design pressure, psi

$\mathrm{R}=$ inside radius, in.

$t=$ min required thickness of shell plates, in.

$E=$ joint efficiency (1.0) (see 1.3, item 14).

She11: $S=\frac{P(R+0.6 t)}{E t}=\frac{10.2[6.75+0.6(0.234)]}{1(0.234)}=$

300 psi less than 6200

These equations are from ASME Code, section VIII, div 1, p 24, UG-34.

Both heads: $S=C P\left(\frac{d}{t}\right)^{2}$ (see 1.3, item 2)

1 Du Pont trademark. 
where:

$\mathrm{C}=$ factor depending on the method of attachment of head, shell dimensions, etc. (dimensionless)

$\mathrm{m}=$ the ratio $\mathrm{t}_{\mathrm{r}} / \mathrm{t}_{\mathrm{s}}$ (dimensionless)

$t_{r}=$ required thickness of seamless shell for pressure, in.

$t_{s}=$ actual thickness of shel1, in.

$\mathrm{S}=$ maximum allowable stress, psi

$P=$ design pressure, psi

$t=$ min required thickness of cover, in.

$\mathrm{d}=\mathrm{dia}$ as measured in 1.3 , item 2, in.

Bottom head:

$\mathrm{S}=\mathrm{CP}\left(\frac{\mathrm{d}}{\mathrm{t}}\right)^{2}=(0.3)(10.2)\left(\frac{13.25}{0.312}\right)^{2}=5520$ psi less than $6200 \underline{\mathrm{OK}}$

Top head:

$\mathrm{S}=\mathrm{CP}\left(\frac{\mathrm{d}}{\mathrm{t}}\right)^{2}=(0.2)(10.2)\left(\frac{13.375}{0.25}\right)^{2}=5840$ psi less than 9500

(see 1.3 , item 13)

$\underline{\mathrm{OK}}$

- Flange and Bolting Operating Condition

These equations are from ASME Code, section VIII, div 1, page No. as noted, UA-47.

$$
\begin{array}{ll}
\mathrm{H}_{\mathrm{D}}=0.785 \mathrm{~B}^{2} \mathrm{P} & \mathrm{p} 235 \\
\mathrm{H}_{\mathrm{G}}=2 \mathrm{~b} \pi \mathrm{G} \mathrm{P} & \mathrm{p} 235 \\
\mathrm{H}_{\mathrm{T}}=0.785\left(\mathrm{G}^{2}-\mathrm{B}^{2}\right) \mathrm{P} & \mathrm{p} 235 \\
\mathrm{~W}_{\mathrm{m} 1}=\mathrm{H}_{\mathrm{D}}+\mathrm{H}_{\mathrm{G}}+\mathrm{H}_{\mathrm{T}} & \mathrm{p} 236 \\
\mathrm{M}_{\mathrm{O}}=\mathrm{h}_{\mathrm{D}} \mathrm{H}_{\mathrm{D}}+\mathrm{h}_{\mathrm{G}} \mathrm{H}_{\mathrm{G}}+\mathrm{h}_{\mathrm{T}} \mathrm{H}_{\mathrm{T}} & \mathrm{p} 235
\end{array}
$$


where:

$$
\begin{aligned}
& \mathrm{H}_{\mathrm{D}}=\text { hydrostatic end force on area inside of flange, } 1 \mathrm{~b} \\
& B=\text { inside dia of flange, in. } \\
& \mathrm{P} \quad=\text { design pressure, psi } \\
& { }_{G}=\text { total joint-contact surface compression load, 1b } \\
& \text { b = effective gasket seating width, in. } \\
& \mathrm{G}=\text { dia at location of gasket load reaction, in. } \\
& \mathrm{m}=\text { gasket factor (see } 1.3 \text {, item 5) } \\
& \mathrm{H}_{\mathrm{T}}=\text { difference between total hydrostatic end force and the } \\
& \text { hydrostatic end force on area inside of flange, } 1 b \\
& \mathrm{~W}_{\mathrm{m} 1}=\text { min required bolt load for the operating conditions, } 1 \mathrm{~b} \\
& \begin{array}{l}
M_{0}=\begin{array}{l}
\text { total moment acting upon the flange for operating conditions, } \\
\text { in. }-1 \mathrm{~b}
\end{array} \\
\text {, }
\end{array} \\
& h_{D, G, T}=\text { radial distance from bolt circle to corresponding forces } \\
& \mathrm{H}_{\mathrm{D}, \mathrm{G}, \mathrm{T}} \\
& \mathrm{H}_{\mathrm{D}}=0.785 \mathrm{~B}^{2} \mathrm{P}=(0.785)(13.5)^{2}(10.2)=14601 \mathrm{~b} ; 1460 \times 0.883= \\
& 1290 \text { in. }-1 b \\
& \mathrm{H}_{\mathrm{G}}=2 \mathrm{~b} \pi \mathrm{GmP}=(2)(0.25) \pi(14.25)(0.5)(10.2)=114 \mathrm{lb} \\
& 114 \times 0.625=71 \text { in. }-1 b \\
& \mathrm{H}_{\mathrm{T}}=(0.785)\left(\mathrm{G}^{2}-\mathrm{B}^{2}\right)(\mathrm{P})=(0.785)\left(14.25^{2}-13.5^{2}\right)(10.2)= \\
& 167 \mathrm{Ib} ; 167 \times 0.812=136 \mathrm{in} \cdot-1 \mathrm{~b} \\
& \mathrm{~W}_{\mathrm{m} 1}=1460+114+167=17411 \mathrm{~b} \\
& \mathrm{M}_{\mathrm{o}}=1290+71+136=1497 \text { in. }-1 \mathrm{~b} \\
& -1-15-
\end{aligned}
$$


These equations are from ASME Code, section VIII, div 1, p 243, UA-49 and UA-50.

$$
\begin{aligned}
\mathrm{W}_{\mathrm{m} 2} & =\pi \mathrm{b} \mathrm{G} \\
\mathrm{A}_{\mathrm{m} 1} & =\frac{\mathrm{N}_{\mathrm{m} 1}}{\mathrm{~S}} \\
\mathrm{~W} & =1 / 2\left(\mathrm{~A}_{\mathrm{m}}+\mathrm{A}_{\mathrm{b}}\right) \mathrm{S}_{\mathrm{a}} \\
\mathrm{M}_{\mathrm{O}} & =\mathrm{Wh}_{\mathrm{G}}
\end{aligned}
$$

where:

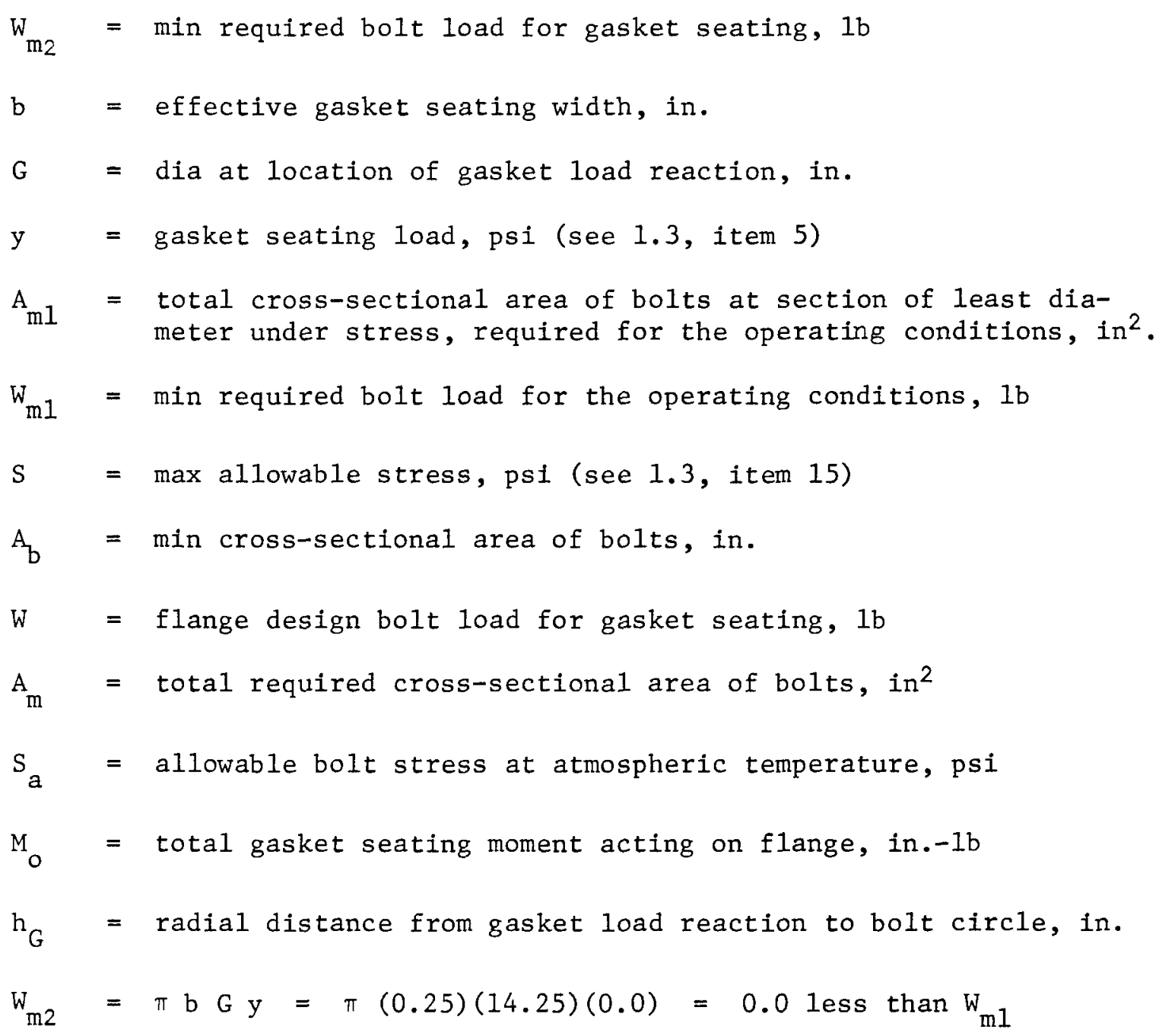




$$
\begin{aligned}
& \mathrm{A}_{\mathrm{m} 1}=\frac{\mathrm{W}_{\mathrm{m} 1}}{\mathrm{~S}}=\frac{1741}{20,000}=0.0870 \mathrm{in}^{2} \\
& \mathrm{~A}_{\mathrm{b}}=8(0.0269)=0.215 \mathrm{in}^{2}(\text { see } 1.3 \text {, item 16) } \underline{\mathrm{OK}} \\
& \mathrm{W}=1 / 2\left(\mathrm{~A}_{\mathrm{m}}+\mathrm{A}_{\mathrm{b}}\right) \mathrm{S}_{\mathrm{a}}=1 / 2(0.0870+0.215)(20,000)=30201 \mathrm{~b} \\
& \mathrm{M}_{\mathrm{O}}=\mathrm{Wh}_{\mathrm{G}}=(3020)(0.625)=1890 \text { in.-1b (gasket seating) }
\end{aligned}
$$

Gasket seating governs

Bolt stress $=\frac{\mathrm{W}}{\mathrm{A}_{\mathrm{b}}}=\frac{3020}{0.215}=14,050 \mathrm{psi}$ less than $20,000 \mathrm{psi}$ OK

For flange constants see 1.3, items 6 through 9 .

Gasket seating: Allowable stress is $6200 \mathrm{psi}$ (see 1.3, item 13).

These equations are from ASME Code, section VIII, div 1, p 244, UA-51.

$S_{H}=\frac{f M_{O}}{L\left(g_{1}\right)^{2} B}$

$S_{R}=\frac{(1.33 t e+1) \text { Mo }}{L t^{2} B}$

$S_{T}=\frac{Y M_{O}}{t^{2} B}-Z S_{R}$

where:

$\mathrm{S}_{\mathrm{H}}=$ calculated longitudinal stress in hub, psi

$\mathrm{f}=$ hub stress correction factor for integral flanges (see 1.3, item 7)

$S_{R}=$ calculated radial stress in flange, psi

$\mathrm{S}_{\mathrm{T}}=$ calculated tangential stress in flange, psi

$\mathrm{M}_{\mathrm{O}}=$ total moment acting on flange for gasket seating or operating conditions, in. $-1 \mathrm{~b}$ 
$\mathrm{L}=$ factor $=\frac{\mathrm{te}+1}{\mathrm{~T}}+\frac{\mathrm{t}^{3}}{\mathrm{~d}}$

$t=$ flange thickness, in.

$\mathrm{T}=$ factor involving $\mathrm{K}$ (ratio of flange $\mathrm{OD}$ to flange ID)

(see 1.3, item 10)

$\mathrm{e}=$ factor for integral flanges $=\mathrm{F} / \mathrm{h}_{\mathrm{O}}$

$F=$ factor for integral flanges (see 1.3, item 11)

involving $g_{1} g_{0}$ where

$\mathrm{g}_{1}=$ thickness of hub at back of flange, in.

$g_{0}=$ thickness of hub at small end, in.

$h_{0}=$ factor $=\sqrt{B g_{0}}$, in.

$\mathrm{d}=$ factor for integral flanges $=\frac{\mathrm{U}}{\mathrm{V}} \mathrm{h}_{0} \mathrm{~g}_{0}{ }^{2}$

$\mathrm{U}=$ factor involving $\mathrm{K}$ (see 1.3 , item 10)

$\mathrm{V}=$ factor for integral type flanges (see 1.3, item 12)

$B=$ inside diameter of flange, in.

$Y \& Z$, see $T$ just listed

$\mathrm{S}_{\mathrm{H}}=\frac{\mathrm{fM}_{\mathrm{O}}}{\mathrm{L}\left(\mathrm{g}_{1}\right)^{2 \mathrm{~B}}}=\frac{(1.0)(1890)}{(0.742)(0.234)^{2}(13.5)}=3450$ less than $1.5(6200)$ OK

$S_{R}=\frac{(1.33 t e+1) M_{0}}{L t^{2} B}=\frac{[(1.33)(0.5)(0.511)+1] 1890}{(0.742)(0.5) 2(13.5)}=$

1010 psi less than 6200

$S_{T}=\frac{Y M_{0}}{t^{2} B}-Z S_{R}=\frac{(10.75)(1890)}{(0.5) 2(13.5)}-(5.55)(1010)=$

$6200-5610=590 \mathrm{psi}$ less than 6200 


$$
\begin{aligned}
& \text { Operating condition } \\
& \mathrm{S}_{\mathrm{H}}=\frac{\mathrm{fM}_{0}}{\mathrm{~L}\left(\mathrm{~g}_{1}\right)^{2 \mathrm{~B}}}=\frac{(1.0)(1497)}{(0.742)(0.234)^{2(13.5)}}=2730 \mathrm{psi} 1.5(6200) \quad \underline{\mathrm{OK}} \\
& S_{R}=\frac{(1.33 t e+1) M_{0}}{L t^{2} B}=\frac{[(1.33)(0.5)(0.511)+1] 1497}{(0.742)(0.5)^{2}(13.5)}= \\
& 801 \text { psi less than } 6200 \\
& \underline{\mathrm{OK}} \\
& S_{T}=\frac{Y_{Q}}{t^{2} B}-Z S_{R}=\frac{(10.75)(1497)}{(0.5) 2(13.5)}-(5.55)(801)= \\
& 4768-4446=322 \mathrm{psi} \text { less than } 6200 \quad \underline{\mathrm{OK}}
\end{aligned}
$$

\section{6 .4 Vibration}

The stainless steel and aluminum containers were shipped for many years without vibration damage. The addition of the insulation and steel drum provides more protection. Therefore, normal vibration will not damage the package.

\subsubsection{Water Spray}

The closed steel drum, with vent holes sealed with metal tape, is impervious to water spray and is not significantly affected.

\section{$\underline{1.6 .6}$ Free Drop}

Two $4 \mathrm{ft}$ drops of the LP-50 packaging were made. First, the LP-50 was dropped at a $45^{\circ}$ angle onto its bottom edge at a point $90^{\circ}$ from the plane of the locking ring lugs at the top of the LP-50. The second drop was also made at a $45^{\circ}$ angle, but this time the LP-50 was dropped onto the top edge when it was in line with the bottom impact point.

Prior to these drops, the PC was evacuated to 100 microns. After these drops and two subsequent drops from $30 \mathrm{ft}$, no detectable change in pressure was found. Minimal damage resulted. See figures 19,20 , and 21.

\subsubsection{Corner Drop}

Since this package is constructed primarily of metal and not wood or fiberboard and also because it weighs more than $110 \mathrm{lb}$, this test is not applicable. 


\subsubsection{Penetration}

A $13 \mathrm{lb}$ 1-1/4 in. dia rod was dropped four feet onto the side of the drum between two chimes. The maximum deflection of the drum was $1 / 4$ in. with no damage to the Celotex ${ }^{\circledR}$ insulation.

\subsubsection{Compression}

An empty drum was uniform $1 y$ loaded to $17001 \mathrm{~b}$ (more than five times its normal package weight). A 2 in. thick plywood load distribution plate was placed on top of an upright drum. Bags of lead shot, weighing $25 \mathrm{lb}$ each, were stacked on the plate to the required total load. After 24 hours, no deformation of the drum had occurred.

\subsection{Hypothetical Accident Conditions}

\section{7 .1 Free Drop}

Three prototype packages were dropped $30 \mathrm{ft}$ on a flat, unyielding horizontal surface. The surface was a 1 in. thick steel plate weighing about $8701 \mathrm{~b}$ supported by a 6 in. thick, $20 \times 30 \mathrm{ft}$ concrete slab on firm soil. A crane with a quick release device was used to suspend each package. The first two packages are described in 2.5.1.2 and the third in 0.2.1.

The first package was dropped on its side with impact on the locking ring lugs. The diameter was reduced $3 / 16$ inch (figure 8 ). The second was dropped on its top corner, resulting in a 3 in. deformation of the corner (figure 13). The third package was first dropped twice from four ft (see 1.6.6) and then dropped on its top corner with the major axis at $15^{\circ}$ to the horizontal. A $2-3 / 4$ in. reduction in diameter resulted (figure 21). None of the three drops resulted in exposure of any of the insulation or any other damage that might affect the ability of the package to withstand the subsequent accident conditions.

\subsubsection{Puncture}

Each of the first two packages mentioned in 1.7 .1 was dropped from a distance of 40 in. onto a 6 in. dia steel post. The post was $10 \mathrm{in.} \mathrm{high} \mathrm{and} \mathrm{welded} \mathrm{to}$ a 1 in. thick $\times 1-1 / 2 \mathrm{ft} \times 1-1 / 2 \mathrm{ft}$ steel plate. The side of the drum was indented $1 / 16$ in. in both cases (figure 9 ).

\subsubsection{Thermal}

\subsubsection{Summary Pressure and Temperature}

Ambient temp $100.4^{\circ} \mathrm{F}\left(38^{\circ} \mathrm{C}\right)$ 
$\Delta$ t shell to ambient $19.8^{\circ} \mathrm{F}\left(11^{\circ} \mathrm{C}\right)$

Temp rise of she11 $114^{\circ} \mathrm{F}\left(63^{\circ} \mathrm{C}\right)$

Max product container temp $242^{\circ} \mathrm{F}\left(117^{\circ} \mathrm{C}\right) 31.6$ psia

\subsubsection{Differential Thermal Expansion}

The furnace test, see 2.5.1.1, did not cause any damage that could be attributed to differential thermal expansion. The calculated expansion of the shell is $0.026 \mathrm{in.}$ in dia and the product container is only $0.018 \mathrm{in}$. in dia.

$$
\begin{array}{lc}
\mathrm{C}_{\mathrm{AI}}=13.7 \times 10^{-6} \mathrm{in} \cdot / \mathrm{in} \cdot{ }^{\circ} \mathrm{F} & \text { Marks Handbook, } 7 \text { th Edition } \\
\mathrm{C}_{\mathrm{SS}}=9.9 \times 10^{-6} \mathrm{in} . / \mathrm{in} .{ }^{\circ} \mathrm{F} & \mathrm{p} 6-10
\end{array}
$$

The clearances, the temperature differential involved, and the thermal expansion coefficients of the materials will minimize the effects of thermal expansion.

\subsubsection{Stress Calculation}

None.

\subsubsection{Comparison with Allowable Stress}

This package has shown by testing that it has withstood any stress developed during actual tests of hypothetical accident conditions. See 2.5.4, Maximum Internal Pressure, for discussion of internal pressure and yield strength.

\subsubsection{Water Immersion}

Not applicable. There is no fissile material in this package.

\subsubsection{Summary of Damage}

A complete package was dropped on a flat surface and on a piston, then heated in a furnace, in the manner prescribed by ERDAM 0529. Three separate tests were performed. The appearance of the package at various stages during the first test is shown in figures 8 through 12, during the second test in figures 13 through 16, and during the third test in figures 19 through 21 . The package was not significantly damaged from the drops in any of the tests. Some insulation damage was caused by smoldering near vent holes after the two thermal tests, but the present design (shown in figure 1) prevents this by the use of a noncombustible insulation in the vicinity of the three vent holes which are provided 
to prevent drum damage by internal gas pressure during a fire. Before the first two tests, the primary container was pressurized to about 29.4 psia. Following the tests, no pressure had been lost and there was no apparent damage to the container valve. During the thermal tests, the surface temperature of the aluminum secondary container was continuously measured. Maximum temperature at various points in the package was determined from the condition of pellets of known melting points. The temperature rise in the furnace test was low enough that tritium permeation and leakage would have been less than the onecurie limit.

Prior to the third $30^{\prime}$ drop test, the package was subjected to two $4 \mathrm{ft}$ drops as described in 1.6.6. The package still passed the test satisfactorily and the PC also held a vacuum of 100 microns without detectable change.

\subsection{Special Form}

Not applicable. No special form is claimed.

\subsection{Fuel Rods}

Not applicable. There are no fuel rods in the shipment. 


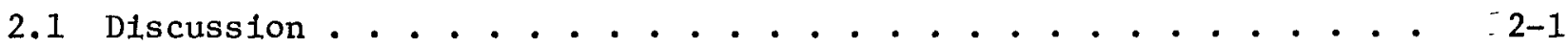

2.1.1 Norma1 Transport . . . . . . . . . . . . . . . 2-1

2.1.2 Hypothetical Accident . . . . . . . . . . . . . 2-1

2.2 Summary of Thermal Properties of Materials . . . . . . . . .

2.3 Technical Spectfications of Components . . . . . . . . . . . 2-2

2.3.1 Celotex . . . . . . . . . . . . . . . 2-2

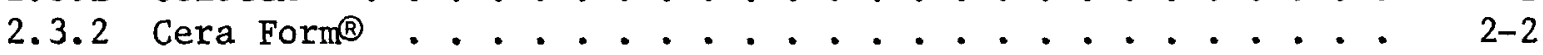

2.3.3 Cerafelt@ . . . . . . . . . ........ . 2-2

2.3.4 Product Container Valves . . . . . . . . . . . 2-2

2.4 Thermal Evaluation for Normal Conditions of Transport . . . . . 2-3

2.4.1 Thermal Model .................... 2-3

2.4.2 Maximum Temperature . . . . . . . . . . . . . 2-8

2.4.3 Minimum Temperature . . . . . . . . . . . . . . $2-8$

2.4.4 Maximum Internal Pressure . . . . . . . . . . . . 2-8

2.4.5 Maximum Thermal Stresses ............... 2-8

2.4.6 Evaluation... . . . . . . . . . . . . . 2-8

2.5 Hypothetical Thermal Accident Evaluation . . . . . . . . . 2-9

2.5.1 Thermal Mode1 . .................. . 2-9

2.5.2 Package Conditions and Environment . . . . . . . . . 2-10

2.5.3 Package Temperatures . . . . . . . . . . . . . 2-10

2.5.4 Maximum Internal Pressure .. . . . . . . . . . . 2-12

2.5.5 Maximum Thermal Stresses . . . . . . . . . . . . 2-12

2.5.6 Eyaluation of Package Performance for the Hypothetical

Accident . . . . . . . . . . . . . . 2-12

2.6 Appendix . . . . . . . . . . . . . . . . . . . 2-13

2.6.1 References .................. . . 2-13 


\subsection{THERMAL EVALUATION}

\subsection{Discussion}

The significant thermal design of the LP-50 packaging is the insulated shipping drum or overpack. A sealed product container (PC) inside an aluminum shell is placed in a Celotex ${ }^{\circledR}$ lined carbon steel drum. See 0.2.1 for a complete description and principal dimensions.

The weighted average thickness of Celotex ${ }^{\circledR}$ is $3.8 \mathrm{in}$. This adequately protects the PC and shell during normal transport and during hypothetical accident conditions. This packaging has been in use for over a decade without adverse effects due to thermal conditions.

The maximum decay heat load is $22.4 \mathrm{Btu} / \mathrm{hr}$. The minimum heat load is zero when the PC is empty. Significant results of the thermal analysis of the package are:

2.1.1 Normal Transport

$\begin{array}{lcll}\text { Drum surface temp sun side } & \left(\mathrm{T}_{\mathrm{d}}\right) & 182.9^{\circ} \mathrm{F} & 83.8^{\circ} \mathrm{C} \\ \begin{array}{lc}\text { Drum surface temp shade side } \\ \text { Wall temp of shell }\end{array} & \left(\mathrm{T}_{\mathrm{d}}{ }^{\prime}\right) & 132.8^{\circ} \mathrm{F} & 56^{\circ} \mathrm{C} \\ \text { Product container temp } & \left(\mathrm{T}_{\mathrm{p}}{ }^{\prime}\right) & 177.2^{\circ} \mathrm{F} & 80.7^{\circ} \mathrm{C} \\ \text { Ambient temp } & \left(\mathrm{T}_{\mathrm{a}}{ }^{\prime}\right) & 179.9^{\circ} \mathrm{F} & 82.1^{\circ} \mathrm{C} \\ \text { Pressure inner vessel } & (\mathrm{P}) & 130^{\circ} \mathrm{F} & 54.4^{\circ} \mathrm{C} \\ \text { Pressure } \Delta \mathrm{P} \text { across wall of inner vessel } & 11.3 \mathrm{psia} & \\ \text { Radioactive heat decay } & \end{array}$

\subsubsection{Hypothetical Accident}

Ambient temp

Temp $\Delta t$ between she11 and ambient

Measured temp rise of shell during furnace test

Temp $\Delta t$ between shell and product container

$\begin{array}{ll}100.4^{\circ} \mathrm{F} & 38^{\circ} \mathrm{C} \\ 18.9^{\circ} \mathrm{F} & 10.5^{\circ} \mathrm{C} \\ 114^{\circ} \mathrm{F} & 63^{\circ} \mathrm{C}\end{array}$

$2.7^{\circ} \mathrm{F} \quad 1.4^{\circ} \mathrm{C}$ 
Temp rise of shell and product container by adiabatic self-heating

$$
4.6^{\circ} \mathrm{F} \quad 3^{\circ} \mathrm{C}
$$

Max product container temp

$242^{\circ} \mathrm{F}$

$117^{\circ} \mathrm{C}$

Pressure of product container at max temp $\quad 31.7$ psia

\subsection{Summary of Thermal Properties of Materials}

a. Celotex ${ }^{\circledR}$ thermal conductivity $0.031 \mathrm{Btu} / \mathrm{hr}-\mathrm{ft}^{2}\left({ }^{\circ} \mathrm{F} / \mathrm{ft}\right)$, density $13-25 \mathrm{lb} / \mathrm{ft}^{3}$

b. Cera Form thermal conductivity $0.028 \mathrm{Btu} / \mathrm{hr}-\mathrm{ft}{ }^{2}\left({ }^{\circ} \mathrm{F} / \mathrm{ft}\right)$, density $11-141 \mathrm{~b} / \mathrm{ft}^{3}$

c. Cerafelt ${ }^{\circledR}$ thermal conductivity $0.025 \mathrm{Btu} / \mathrm{hr}-\mathrm{ft}^{2}\left({ }^{\circ} \mathrm{F} / \mathrm{ft}\right)$, density $6 \mathrm{lb} / \mathrm{ft}^{3}$

d. Cerafelt $\mathrm{t}^{\circledR}$ thermal conductivity $0.027 \mathrm{Btu} / \mathrm{hr}-\mathrm{ft}\left({ }^{\circ} \mathrm{F} / \mathrm{ft}\right)$, density $16 \mathrm{lb} / \mathrm{ft}^{3}$

e. Solar flux $144 \mathrm{Btu} / \mathrm{hr} / \mathrm{ft}^{2}$ [ORNL-NSIC-68, Cask Designers Guide, p 143]

f. AIr thermal conductivity $0.0175 \mathrm{Btu} / \mathrm{hr}-\mathrm{ft} \mathrm{t}^{2}\left({ }^{\circ} \mathrm{F} / \mathrm{ft}\right)$ @ $177^{\circ} \mathrm{F}$ [Marks Handbook for Mechanical Engineers, 7th ed, p 4-94, 1967]

g. Absorptivity factor - painted surface $=0.94$ [ORNL-NSIC-68, p 133]

\subsection{Technical Specifications of Components}

2.3.1 Celotex ${ }^{\circledR}$ fiberboard made from sugar cane fibers bonded with organic glue per Mil F-26862A. Sheer strength $31-33$ psi, stable to $250^{\circ} \mathrm{F}$.

2.3.2 Cera Form - molded from slurry of alumina silica refractory fiber and bonded by inorganic binders, stable to $2300^{\circ} \mathrm{F}$.

2.3.3 Cerafelt ${ }^{\circledR}$ - A loosely spun alumina-silica refractory material, stable to $2300^{\circ} \mathrm{F}$.

\subsubsection{Product Container Valves}

Three slightly different valves are used: a Fulton Sylphon, a modified Fulton Sylphon, and a Hoke $4312 \times 2$. The valves were tested for tritium leakage at $25^{\circ}$ and $110^{\circ} \mathrm{C}$ with differential pressures of $570-950$ torrs. The Hoke valve has a proof test of $3000 \mathrm{psig}$ and a max operating temperature of $600^{\circ} \mathrm{F}$. The Fulton Sylphon valves are prooftested at 150 psig.

At $25^{\circ} \mathrm{C}$, leakage was well below the $7 \times 10^{-8}$ atm cc/sec limit. At $110^{\circ} \mathrm{C}$ leakage was still insignificant when compared with the $0.39 \mathrm{cc}$ (1 curie) loss allowed under accident conditions. [IAEA Safety Series No. 6) "Regulations for the Safe Transport of Radioactive Materials," 1973 Revised edition, section II, $\mathrm{p} 230$, (b).] 


\subsection{Therma1 Evaluation for Normal Conditions of Transport}

\subsubsection{Thermal Model}

The standard packaging described in 0.2.1, and shown in detail in the reference drawings cited in the Contents (S5-2-5733 et seq) serves as a model for the thermal evaluation.

\subsubsection{Therma1 Evaluation}

The thermal evaluation for normal transport was made analytically following the methods and equations of ORNL-NSIC-68 using thermal conductivities from manufacturers technical data sheets. The assumptions used in the calculations follow.

- Assumptions

1) The package is in thermal equilibrium at $130^{\circ} \mathrm{F}$ ambient air temperature in sunlight at latitude $42^{\circ} \mathrm{N}$ during the summer solstice ( $144 \mathrm{Btu} / \mathrm{hr}-$ $\mathrm{ft}^{2}, 24$-hour average solar heat rate).

2) Solar heating is applied to the top and one side of the drum over a projected area equal to diagonal height times diameter.

3) There is no circumferential heat flow in the thin wall of the drum or In the Celotex insulation.

4) Heat escape through the bottom of the package is neglected.

5) The wall temperature of the aluminum shell is uniform (high conductivity, low heat flux).

6) Heat passage from the sunny surfaces of the drum to the aluminum shell, thence to the shaded surface of the drum, is calculated on the basis of a weighted average insulation thickness.

- Definitions and Constants

1) $Q_{S}=$ solar heat input = solar radiation $x$ projected area $x$ absorptivity factor

Solar radiation $=144 \mathrm{Btu} / \mathrm{hr}-\mathrm{ft}^{2}$ [1]

Absorptivity factor $=0.94$ [2] for a painted drum 


$$
\begin{aligned}
& \text { Projected area }=\text { diagonal height } \times \text { diameter } \\
&= \frac{\sqrt{(22.5)^{2}+(38.5)^{2}} \times 22.5}{144}=6.97 \mathrm{ft}^{2} \\
& Q_{\mathrm{S}}= 144 \times 6.97 \times 0.94=943.46 \mathrm{Btu} / \mathrm{hr} \\
& \text { 2) } \mathrm{Q}_{\mathrm{R}}= 0.32 \mathrm{watt} / \mathrm{g} \mathrm{tritium} \times 3.4139 \mathrm{Btu} / \mathrm{watt} / \mathrm{hr} \times 75,300 \mathrm{cc} \text { in } \\
& 50 \text { liters }+3718 \mathrm{cc} / \mathrm{g} \mathrm{tritium}=22.4 \mathrm{Btu} / \mathrm{hr} \\
& \text { (vessel @ } 1250 \text { torr) }
\end{aligned}
$$

3) $A_{d}=$ surface area of drum (sun side)

$=$ top surface $+1 / 2$ cylindrical surface

$=12.2 \mathrm{ft}^{2}$

4) $A^{\prime} d=$ surface area of drum (shade side)

$=1 / 2$ cylindrical surface

$=9.45 \mathrm{ft}^{2}$

5) $U_{0}=$ heat transfer coefficient through insulation (sun side)

$=\frac{\mathrm{K}}{\mathrm{L}}=\frac{0.038}{0.36}=0.106 \mathrm{Btu} / \mathrm{hr}-\mathrm{ft}{ }^{2}\left({ }^{\circ} \mathrm{F}\right)$

$\mathrm{K}=$ thermal conductivity of Celotex in temp range of $85^{\circ}$ to $90^{\circ} \mathrm{C}$

$=0.038$, estimated from room temp conductivity of 0.030 $\mathrm{Btu} / \mathrm{hr}-\mathrm{ft} \mathrm{t}^{2}\left({ }^{\circ} \mathrm{F} / \mathrm{ft}\right)$

$\mathrm{L}=$ weighted average insulation thickness of $3.8 \mathrm{in} .+0.5 \mathrm{in}$. of Celotex equivalent of air gap of $0.36 \mathrm{ft}$

6) $U_{0}^{\prime}=$ heat transfer coefficient through insulation (shade side)

$$
=\frac{\mathrm{K}^{\prime}}{\mathrm{L}^{\top}}
$$

$$
\begin{aligned}
& \mathrm{K}^{\prime}=0.036 \text { estimated }\left(158^{\circ} \mathrm{F} / 70^{\circ} \mathrm{C}\right) \\
& \mathrm{L}^{\prime}=0.36 \mathrm{ft}
\end{aligned}
$$

$=\frac{0.036}{0.36}=0.10 \mathrm{Btu} / \mathrm{hr}-\mathrm{ft}^{2}\left({ }^{\circ} \mathrm{F}\right)$ 
7) $\mathrm{A}_{\mathrm{m}}=$ mean heat transfer area (sun side)

$=$ mean area of drum top $+1 / 2$ mean area of cyl side

$=1.84 \mathrm{ft}^{2}+6.14 \mathrm{ft}^{2}=7.98 \mathrm{ft}^{2}$

8) $\mathrm{A}_{\mathrm{m}}^{\prime}=1 / 2$ mean heat transfer area (shade side)

$=$ mean area of cyl side $=6.14 \mathrm{ft}^{2}$

9) $\mathrm{T}_{\mathrm{d}}=$ drum surface temperature - sun side, ${ }^{\circ} \mathrm{F}$

10) $\mathrm{T}_{\mathrm{d}}^{\prime}=$ drum surface temperature - shade side, ${ }^{\circ} \mathrm{F}$

11) $\mathrm{T}_{\mathrm{c}}=$ wall temperature of aluminum vessel, ${ }^{\circ} \mathrm{F}$

12) $\mathrm{T}_{\mathrm{a}}=$ ambient temperature $=54^{\circ} \mathrm{C}\left(130^{\circ} \mathrm{F}\right)$

\section{- Calculations}

1) Heat Balances

For determination of temperatures $T_{d}, T^{\prime}{ }_{d}$, and $T_{c}$, heat balances are made on the entire package, the aluminum vessel, and the separate sides of the steel drum.

\section{SHADE SIDE}

SUN SIDE

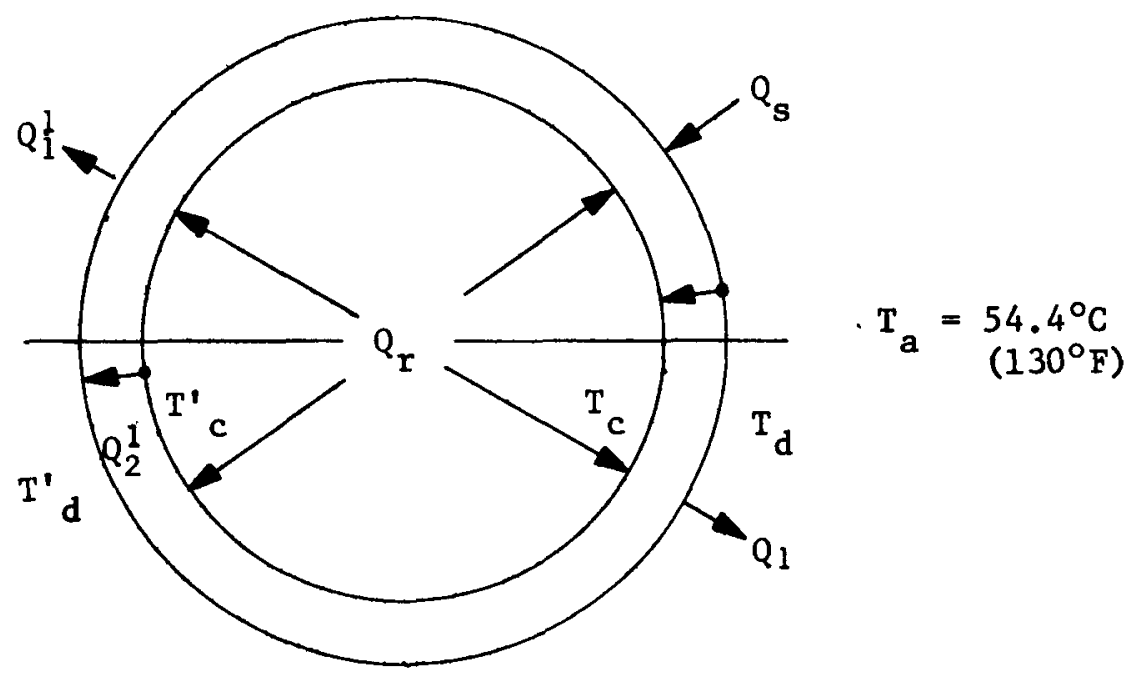


Entire package

$Q_{\text {in }}=Q_{\text {out or }} Q_{S}+Q_{r}=Q_{1}+Q_{1}^{\prime}$

$$
Q_{s}+Q_{r}=Q_{1}+Q_{1}^{\prime}
$$

$943.36+22.4=\left(h_{c}+h_{r}\right) A_{d}\left(T_{d}-T_{a}\right)+\left(h^{\prime}{ }_{c}+h^{\prime}{ }_{r}\right) A^{\prime}{ }_{d}$

$$
\left(T^{\prime} d-T_{a}\right)
$$

where:

$$
\begin{aligned}
& h_{c}=0.19(\Delta \mathrm{T})^{1 / 3} \text { ORNL-NSIC-68 }-\mathrm{p} 135 \\
& \mathrm{~h}_{\mathrm{r}}=0.173 \times \mathrm{F}_{\mathrm{a}} \mathrm{F}_{\mathrm{e}}\left[\frac{\left(\frac{\mathrm{T}_{\mathrm{d}}+460}{100}\right)^{4}-\left(\frac{\mathrm{T}_{\mathrm{a}}+460}{100}\right)^{4}}{\mathrm{~T}_{\mathrm{d}}-\mathrm{T}_{\mathrm{a}}}\right] \\
& \mathrm{F}_{\mathrm{a}}=\text { Angle factor }=1.0 \text { direct sunlight } \\
& \mathrm{F}_{\mathrm{e}}=\text { Emissivity factor }=0.94
\end{aligned}
$$

$$
\begin{aligned}
& \text { Q in } \underline{\text { Q out }} \\
& \text { Aluminum } Q_{r}+Q_{2}=Q_{2}^{\prime} \\
& \text { Container } \quad Q_{r}+U_{o} A_{m}\left(T_{d}-T_{c}\right)=U_{0}^{\prime} A_{m}^{\prime}\left(T_{c}-T_{d}^{\prime}\right) \\
& \text { Steel drum sun side } \quad Q_{S} \quad=\quad Q_{1}+Q_{2} \\
& \text { Steel drum shade side } \quad Q^{\prime}{ }_{2} \quad Q^{\prime}{ }_{1}
\end{aligned}
$$

By successive substitution of trial values in the above equations, it is found that the following set of temperatures is required for equilibrium.

$$
\begin{aligned}
& \text { Drum - sunny side }\left(\mathrm{T}_{\mathrm{d}}\right)=182.9^{\circ} \mathrm{F}\left(83.8^{\circ} \mathrm{C}\right) \\
& \text { Drum - shaded side }\left(\mathrm{T}^{\prime}{ }_{\mathrm{d}}\right)=132.8^{\circ} \mathrm{F}\left(56^{\circ} \mathrm{C}\right) \\
& \text { Aluminum she11 }\left(\mathrm{T}_{\mathrm{c}}\right)=177.2^{\circ} \mathrm{F}\left(80.7^{\circ} \mathrm{C}\right)
\end{aligned}
$$


2) Temperature Gradient Between PC and Shell

To determine the temperature of the PC (and tritium), it is necessary

to estimate the temperature gradient between the PC and the shell.

$\mathrm{T}_{\mathrm{c}}=$ Temperature of aluminum shell $=177.2^{\circ} \mathrm{F}\left(80.7^{\circ} \mathrm{C}\right)$

$\mathrm{T}_{\mathrm{S}}=$ Temperature of stainless steel $\mathrm{PC},{ }^{\circ} \mathrm{F}$, to be determined

$A_{c o}=$ Area for heat transfer by conduction

$=$ Cylindrical surface only (large clearances at top and bottom of the PC 22.828 in.) $=6.55 \mathrm{ft}^{2}$

$\mathrm{L}=$ clearance between cylindrical surfaces $=0.17 \mathrm{in} .=0.014 \mathrm{ft}$

$A_{r}=$ area for heat transfer by radiation

$=$ entire surface of $P C=8.0 \mathrm{ft}^{3}$

Heat balance: $Q_{r}=h_{c o} A_{c o}\left(T_{s}-T_{c}\right)$

where:

$\mathrm{Q}_{\mathrm{r}} \quad$ = radioactive decay heat $=22.4 \mathrm{Btu} / \mathrm{hr}$

$\mathrm{h}_{\mathrm{co}}=$ heat transfer coefficient by conduction $=\frac{\mathrm{K} \text { air }}{\mathrm{L}}=$

$=\frac{0.0175 \mathrm{Btu} /(\mathrm{hr})\left(\mathrm{ft}^{2}\right)\left({ }^{\circ} \mathrm{F} / \mathrm{ft}\right)}{0.014 \mathrm{ft}}=1.25 \mathrm{Btu} / \mathrm{hr}-\mathrm{ft}^{2}\left({ }^{\circ} \mathrm{F}\right)$

$\mathrm{K}_{\text {air }} @ 177^{\circ} \mathrm{F}=0.0175 \mathrm{Btu} / \mathrm{hr} \mathrm{ft}^{2}$ [Marks Handbook 7 th Edition 4-94 Steam]

$\mathrm{T}_{\mathrm{s}}-\mathrm{T}_{\mathrm{c}}=\frac{\mathrm{Q}_{\mathrm{r}}}{\mathrm{h}_{\mathrm{co}} \cdot \mathrm{A}_{\mathrm{co}}}=\frac{22.4}{(1.25)(6.55)}=2.74$

$\mathrm{T}_{\mathrm{s}}-177.2=2.7$

$\mathrm{T}_{\mathrm{S}}-179.9^{\circ} \mathrm{F}\left(82.1^{\circ} \mathrm{C}\right)$

There will be no significant difference in temperature between the tritium and the inner vessel; therefore, the temperature of the tritium in normal transport will not exceed $180^{\circ} \mathrm{F}\left(82^{\circ} \mathrm{C}\right)$. 
The maximum temperatures for normal transport conditions are:

$\begin{array}{lll}\text { Steel drum } & 182.9^{\circ} \mathrm{F} & 83.8^{\circ} \mathrm{C} \\ \text { Shel1 wall } & 177.2^{\circ} \mathrm{F} & 80.7^{\circ} \mathrm{C} \\ \text { Product container } & 179.9^{\circ} \mathrm{F} & 82.1^{\circ} \mathrm{C}\end{array}$

\subsubsection{Minimum Temperature}

This is a dry shipment and contains no liquids or other material harmfully affected by a temperature of $-40^{\circ} \mathrm{F}\left(-40^{\circ} \mathrm{C}\right)$.

\subsubsection{Maximum Internal Pressure}

The maximum initial loading pressure is 24.2 psia (1250 torrs) at $25^{\circ} \mathrm{C}$. The maximum pressure during normal transport will be at maximum temperature in the PC (see 2.4.2).

PC pressure $(24.2)\left(\frac{82+273}{25+273}\right)=28.8$ or 29 psia

The maximum temperature for the shell is taken to be the average temperature. The initial shell pressure is 1 atmosphere at $25^{\circ} \mathrm{C}$.

$$
\frac{\mathrm{T}_{\mathrm{PC}}+\mathrm{T}_{\text {she11 }}}{2}=81.4^{\circ} \mathrm{C} \quad \mathrm{P}=14.7\left[\frac{81.4+273}{25+273}\right]=17.5 \mathrm{psia}
$$

The ability of the packaging to withstand this pressure is shown in 1.6.3.

\subsubsection{Maximum Therma1 Stresses}

The temperature differentials throughout the package are relatively small and will cause no significant thermal stresses.

\subsubsection{Evaluation}

The packaging has provided effective protection for many shipments over the past decade.

The package will not be affected by maximum full sunlight temperatures of $130^{\circ} \mathrm{F}$ $\left(54^{\circ} \mathrm{C}\right)$ as the maximum internal temperature will not exceed $180^{\circ} \mathrm{F}\left(82^{\circ} \mathrm{C}\right)-$ well under the $250^{\circ} \mathrm{F}\left(121^{\circ} \mathrm{C}\right)$ plus temperatures that affect the insulating material. Minimum $\left(-40^{\circ} \mathrm{F}\right.$ or $\left.-40^{\circ} \mathrm{C}\right)$ temperatures will produce no detrimental effects on the packaging as this is a dry shipment. 
The effects of pressure as calculated in section 1.6 .3 show that the product container and shell will withstand normal transport conditions.

Vibration and water spray do not effect the packaging (see 1.6.4 and 1.6.5). Free drops and penetration tests had no significant effect on the package (see 1.6 .7 and 1.6.8).

The package had no deformation after the compression test (see 1.6.9).

\subsection{Hypothetica1 Thermal Accident Evaluation}

\subsubsection{Therma1 Model}

\subsubsection{Analytical Model}

The standard packaging described in 0.2 .1 and shown in detail on drawings S5-2-5733 et. seq. serves as a model for the calculations made to extend the thermal test results to packaging components whose temperatures were not directly measured.

\subsubsection{Test Model}

The test model used for both drop and thermal tests is ident al to the packaging described in 0.2 .1 with three minor exceptions:

a. To eliminate smoldering which developed in the top ring of Celotex ${ }^{\circledR}$ insulation in the vicinity of the drum vent holes during the postfire cooldown period, the affected insulation was replaced in the final design (0.2.1) with a ring of noncombustible Cera Form (felt) insulation. Subsequent tests on numerous packagings of this generic design indicated no adverse affect of this substitution on either the drop or other test results (none was expected), and no recurrence of smoldering. Two effects are assumed as possible sources of this improvement: (1) replacement of a combustible insulation with a noncombustible type in a zone where postfire smoldering could occur and (2) reduction of air permeation into the drum via the vents as a result of the fine-spun structure of Cera Form ${ }^{\circledR}$ which is known to restrict air flow at small differential pressures.

b. Also, in the final design, a disk of Cerafelt ${ }^{\circledR}$ is specified under the drum cover on top of the Celotex ${ }^{\circledR}$. Cerafelt ${ }^{\circledR}$ is stable up to $2300^{\circ} \mathrm{F}$ and may prevent burning or smoldering of the Celotex even if the closure is breached, assuming no Celotex ${ }^{\circledR}$ is exposed. Equally important, the disk serves as a spacer to ensure that the insulation is tightly constrained to avoid breaching the closure. Several $1 / 2$ in. thicknesses may be used if required. 
c. Lastly, a coating of Cera-kote $e^{\circledR}$ is applied to the Celotex ${ }^{\circledR}$, Cera-kote ${ }^{\circledR}$ stabilizes the irritating dust and larger particles of cane fiber gradually released from the Celotex ${ }^{\circledR}$ surface. Therefore, Cera-kote ${ }^{\circledR}$ was specified for the final design. For a full account of the development program for this type of package, see reference in section 2.6.

A complete package was dropped on a flat surface and on a piston, then heated in a furnace, in the manner prescribed by ERDAM 0529. Two separate tests were performed.

A large annealing furnace was used for thermal tests on full-scale packages. After the furnace was heated to $1475^{\circ} \mathrm{F}$, the package was inserted for 30 minutes, then removed for cooling. A thermocouple, inserted through the drum, measured the temperature of the aluminum shell just inside the insulation.

The maximum temperature at various other points was determined from the condition of pellets of known melting points.

The package tested contained no radioactive material.

\subsubsection{Package Conditions and Environment}

The appearance of the package at various stages during the drop and piston tests is shown in figures 8 through 21. The package was not significantly damaged by the drop tests, and therefore the tests were not detrimental to the cask during the furnace tests.

\subsubsection{Package Temperatures}

During the thermal tests some insulation damage was caused by smoldering near vent holes, but the present design (shown in figure 1) prevents this by the use of noncombustible insulation in the vicinity of the three vent holes (these holes are provided to prevent drum damage by internal gas pressure during a fire). Before the tests, the primary container was pressurized to about 29.4 psia. Following the test, no pressure had been lost and there was no apparent damage to the container valve. During the thermal tests, the surface temperature of the aluminum shell was continuously measured. The initial temperature of the $\mathrm{PC}$ was $24^{\circ} \mathrm{C}$. The maximum temperature reached from the fire was $87^{\circ} \mathrm{C}$ $\left(189^{\circ} \mathrm{F}\right)$, a rise of $63^{\circ} \mathrm{C}$. The smoldering in the insulation began noticeably showing the temperature decline after about 250 minutes, eventually causing it to level at an abnormally high value. However, extrapolation of the initial part of the decline, shown by the dashed line in figure 18 , produces a curve similar to what would be obtained without smoldering and allows an approximation of the time at elevated temperature tritium permeation calculations. The temperature rise in the furnace test is low enough that tritium permeation and leakage are less than the 1 curie limit. 
- Temperature Calculations

The maximum temperature of a loaded primary container in a fire is less than the sum of the following:

1) Calculated temperature of the aluminum shell before the fire.

2) Measured temperature rise of the aluminum shell during the furnace test $\left(114^{\circ} \mathrm{F}\right.$ or $\left.63^{\circ} \mathrm{C}\right)$.

3) Calculated temperature difference between the PC and the aluminum she11 $\left(2.7^{\circ} \mathrm{F}\right.$ or $\left.1.5^{\circ} \mathrm{C}\right)$. (see 2.4.1).

4) Calculated temperature rise of the PC and the shell vessels caused by adiabatic self-heating while the temperature is elevated from the fire (see 2.4.1).

The temperature before the fire is calculated on the basis of still ambient air at $38^{\circ} \mathrm{C}$ without solar radiation. Using values of $h_{\mathrm{e}}$ and $h_{r}$ as in 2.4.1 and an effective area of $21.6 \mathrm{ft}^{2}$ for dissipation of heat from the cylindrical surface and one end of the drum, it is found that the outer surface temperature is about $1^{\circ} \mathrm{C}\left(1.8^{\circ} \mathrm{F}\right)$ above ambient. For a mean heat transfer area of $14.2 \mathrm{ft}^{2}$ through the Celotex, ${ }^{\circledR}$ an effective thickness of $0.36 \mathrm{ft}$ and a thermal conductivity of $0.030 \mathrm{Btu} /(\mathrm{hr})(\mathrm{ft})\left({ }^{\circ} \mathrm{F}\right)$ (see 2.4.1), the temperature drop through the Celotex is -

$\frac{22.4 \mathrm{Btu} / \mathrm{hr} \times 0.36 \mathrm{ft}}{14.2 \mathrm{ft} \mathrm{t}^{2} \times 0.030 \mathrm{Btu} /(\mathrm{hr})(\mathrm{ft})\left({ }^{\circ} \mathrm{F}\right)}=18.9^{\circ} \mathrm{F}\left(10.5^{\circ} \mathrm{C}\right)$

The temperature drop between the aluminum shell and the Celotex ${ }^{\circledR}$ was taken into account in the effective thickness of the Celotex. ${ }^{\circledR}$ Therefore, the calculated temperature of the aluminum shell is

$100.4+1.8+18.9=121.1^{\circ} \mathrm{F}\left(49.5^{\circ} \mathrm{C}\right)$.

The temperature difference between the two inner containers is calculated in 2.4 .1 to be $2.7^{\circ} \mathrm{F}\left(1.5^{\circ} \mathrm{C}\right)$.

Self-heating following a fire is calculated as follows:

[(Self-heating time from figure 18) $\times$ (tritium decay heat rate)] divided by (mass of primary container $x$ specific heat of stainless stee $1+$ mass of aluminum shell $\times$ specific heat of aluminum $)=$ temperature rise.

( 3 hours) $(22.4$ Btu/hr)

$\left(30.51 \mathrm{~b}\right.$ stee1) $\left[0.12 \mathrm{Btu} /(1 \mathrm{~b})\left({ }^{\circ} \mathrm{F}\right)\right]+(47 \mathrm{lb} \mathrm{A} 1)\left[0.23 \mathrm{Btu} /(1 \mathrm{~b})\left({ }^{\circ} \mathrm{F}\right)\right]$

$=4.6^{\circ} \mathrm{F}\left(2.6^{\circ} \mathrm{C}\right)$ 
The sum of the preceding temperatures is the maximum primary container temperature following a fire; $121.1+114.0+2.7+4.6=$ $242.4^{\circ} \mathrm{F}\left(116.7^{\circ} \mathrm{C}\right)$.

\subsubsection{Maximum Internal Pressure}

The initial tritium loading pressure will be 24.2 psia at $25^{\circ} \mathrm{C}$ which will not cause yielding of the container at the fire temperature of about $242^{\circ} \mathrm{F}\left(117^{\circ} \mathrm{C}\right)$. This was determined as follows:

As the primary container temperature increases, the internal pressure increases, but the container yield pressure decreases (yield pressure is defined as that which produces a $0.2 \%$ permanent strain). For a cylinder, yield pressure is directly proportional to yield strength (yield strength of type $304 \mathrm{~L}$ SS as a function of temperature is listed in the ASME Code, section III, 1965 edition, table $\mathrm{N}-424)$. Thus:

$$
\frac{P_{117}}{P_{25}}=\frac{s_{117}}{S_{25}}
$$

where:

$P=y i e 1 d$ pressure, gage

$S=$ yield strength

The yield pressure at $25^{\circ} \mathrm{C}$ was determined experimentally to be 30 psig.

$$
\frac{\mathrm{P}_{117}}{30}=\frac{20,000}{25,000} \text { or } \mathrm{P}_{117}=24.0 \text { psig or } 38.7 \mathrm{psia}
$$

An initial pressure of 24.2 psia at $25^{\circ} \mathrm{C}$ will be 31.7 psia at $117^{\circ} \mathrm{C}$; therefore, the container pressure would not reach the yield pressure during the thermal accident.

\subsubsection{Maximum Thermal Stresses}

The package was tested in such a manner that the initial pressure of the product container was 29.4 psia which is equivalent to a pressure of 33 psia at $114^{\circ} \mathrm{F}$. There was no pressure loss when the PC was opened at the conclusion of the test.

\subsubsection{Evaluation of Package Performance for the Hypothetical Thermal Accident}

The package evaluation indicates that it will withstand the accident conditions Indicated in 10 CFR 71 Appendix B. The package was not significantly damaged 
during the free drop and puncture tests.

Furnace tests and calculations show the maximum product container temperature and pressure to be $242^{\circ} \mathrm{F}\left(117^{\circ} \mathrm{C}\right)$ and $31.7 \mathrm{psia}$. Yield pressure at $117^{\circ} \mathrm{C}$ is 38.7 psia.

The water immersion test was not done because there is no fissile material in this package.

Limited smoldering that occurred during the initial thermal testing was eliminated by using noncombustible insulation, Cera Form, ${ }^{\circledR}$ near the drum vent holes. The Cera Form extended into the Celotex ${ }^{\circledR}$ for $1-1 / 2$ inches, the maximum char depth observed on any test.

\subsection{Appendix}

\subsubsection{References}

1. Lewallen, E. E., Drum and Board-Type Insulation Overpacks of Shipping Packages for Radioactive Materials, July 1972. USAEC Report DP-1292, E. I. du Pont de Nemours and Co., SRL, Aiken, S. C. 29801. 
3.1 Containment Boundary . . . . . . . . . . . . . . 3-1'

3.1.1 Containment Vesse1 . . . . . . . . . . . . . 3-1

3.1.2 Containment Penetrations ............... . . 3-1

3.1.3 Seals and Welds . . . . . . . . . . . . . . . . . 3-1

3.1.4 Closure . . . . . . . . . . . . . . . . 3-1

3.2 Requirements for Normal Conditions of Transport . . . . . . . 3-1

3.2.1 Release of Radioactive Material . . . . . . . . . . 3-1

3.2.2 Pressurization of Containment Vesse1 . . . . . . . . 3-2

3.2.3 Coolant Contamination .............. 3-2

3. 3 Containment Requirements for the Hypothetical Accident . . . . . . 3-4

3.3.1 Fission Gas Products . . . . . . . . . . . . . 3-4

3.3.2 Release of Contents ................. . . 3-4

3.4 Appendix . . . . . . . . . . . . . . . . . . 3-6

3.4.1 References ..................... . . . . . . . 


\subsection{CONTAINMENT}

\subsection{Containment Boundary}

\subsubsection{Containment Vessel}

The containment vessel is the product container (PC). It is a 50-liter right circular cylinder made of $0.078 \mathrm{in}$. thicl type $304 \mathrm{~L}$ stainless steel. See figure 5 for details of specifications for cleanliness and leaktightness.

\subsubsection{Containment Penetrations}

The only penetration of the PC is a $1 / 4 \mathrm{in.} \mathrm{hole,} \mathrm{through} \mathrm{the} \mathrm{cover,} \mathrm{into}$ which a vacuum valve is welded. Originally, all PC's were equipped with the vacuum valve shown in figure 7 . Other similar valves have since been used as replacements. The latest type is a SS Hoke valve, model No. 4213X2. It can operate at $2000 \mathrm{psig}$ and $600^{\circ} \mathrm{F}$ and has a leakage rate less than $8 \times 10^{-9} \mathrm{cc} / \mathrm{s}$.

\subsubsection{Seals and Welds}

The cover is attached to the PC with an edge weld with an inert gas arc weld and no filler material. The vacuum valve is welded - with a 1/16 in. dia type 308L SS rod (using heliarc) - into the $1 / 2$ in. dia countersunk hole at the top of the $1 / 4 \mathrm{in.}$ dia hole through the cover.

\section{1 .4 Closure}

In order to maintain a positive seal, the three types of valves in use are tightened sufficiently to maintain a leak rate of less than one micron-ft ${ }^{3} / \mathrm{hr}$.

\subsection{Requirements for Normal Conditions}

\section{of Transport}

\subsubsection{Release of Radioactive Material}

Gaseous tritium permeates normal materials of construction at rates depending on temperature, pressure, and other factors. The term "no release" as used for normal conditions of transport is interpreted to mean no release which would expose any persons to a dose above that received by continuous exposure to the maximum permissible concentration allowed for the public. For transportation in a closed vehicle (the worst case), the maximum allowable release rate per package would be about $7 \times 10^{-8} \mathrm{~atm} \mathrm{cc} / \mathrm{sec}$ of tritium. This value is derived by assuming that air in a closed vehicle is replaced about once a day, that a 
vehicle contains about $300 \mathrm{ft}^{3}$ of air for every package, and that a workman opening and unloading the vehicle would be exposed to the maximum concentration for no more than one minute. The maximum concentration in the vehicle is computed from the maximum permissible concentration for 168 hour/week exposure set by the ERDAM 0524 [1] Concentration Guide by the ratio of exposure time to 168 hours. The actual exposure would be much lower than the calculated because actual tritium release rates will be greatly below the derived upper limit. (It is interesting to note that the IAEA regulations would permit escape of $1.1 \times 10^{-7} \mathrm{~atm} \mathrm{cc} / \mathrm{sec}$. [2, section II, para $\left.230(\mathrm{a}).\right]$

\subsubsection{Pressurization of Containment Vessel}

At a release rate of $7 \times 10^{-8} \mathrm{~atm} \mathrm{cc} / \mathrm{sec}$ for 30 days of transportation, the mol fraction of hydrogen isotopes in the shell will be:

$$
\begin{aligned}
& \frac{7 \times 10^{-8} \mathrm{~atm} \mathrm{cc} / \mathrm{sec} \times 30 \text { days } \times 24 \mathrm{hr} / \mathrm{day} \times 3600 \mathrm{sec} / \mathrm{hr}}{5200(\text { chamber volume })} \\
& =3.5 \times 10^{-5} \text { or } 0.004 \% \text { tritium }
\end{aligned}
$$

Even if the ratio of deuterium + protium to tritium were 10 , the mixture is not ignitable because the hydrogen concentration in air is less than $4 \%$, the lower limit. The corresponding pressure increase would also be insignificant; consequently, there is no danger of creating an explosive mixture under conditions of normal transport.

\subsubsection{Coolant Contamination}

No coolant as such is put into the package. However, the calculations and explanations below describe the permeation phenomena of tritium from the PC into the shell.

Equilibrium hydrogen permeation through type 304L stainless steel

at $82^{\circ} \mathrm{C}$ is $1.5 \times 10^{-7} \frac{\mathrm{STP} \mathrm{cc} \mathrm{mm}}{\left(\mathrm{cm}^{2}\right)(\mathrm{hr})}$ at 760 torrs $[3, \mathrm{p} 6]$

Corrected for pressure, surface area, and wall thickness, the permeation rate becomes:

$\frac{1.5 \times 10^{-7} \mathrm{sTP} \mathrm{cc} \mathrm{mm} \times 8040 \mathrm{~cm}^{2}}{(3600 \mathrm{sec} / \mathrm{hr})\left(\mathrm{cm}^{2}\right)(\mathrm{hr}) \times 1.98 \mathrm{~mm}} \quad \sqrt{\frac{28.8}{14.7}}=2.4 \times 10^{-7} \mathrm{~atm} \mathrm{cc} / \mathrm{sec}$ 
A very long time, however, is required to reach equilibrium rate. The time to reach $7 \times 10^{-8} \mathrm{~atm} \mathrm{cc} / \mathrm{sec}$ is obtained from a graphical plot of

$\frac{P_{t}}{P_{\infty}}$ vs $\frac{D t}{L^{2}} \quad\left[3, p\right.$ 5] and the equation $D=0.0265 \times \mathrm{e}^{-14,000 / R T}$ [4, p 2]

where

$\mathrm{P}_{t}=$ permeation rate at time $\mathrm{t}$ or $7 \times 10^{-8} \mathrm{~atm} \mathrm{cc}$ tritium/sec

$\mathrm{P}_{\infty}=$ permeation rate at equilibrium, atm $\mathrm{cc} / \mathrm{sec}$

$\mathrm{D}=$ diffusion rate, $\mathrm{cm}^{2} / \mathrm{sec}$

$\mathrm{R}=$ gas constant, $\mathrm{g}-\mathrm{cal} /(\mathrm{g}-\mathrm{mole})\left({ }^{\circ} \mathrm{K}\right)=1.987$

$\mathrm{T}=$ temperature ${ }^{\circ} \mathrm{K}={ }^{\circ} \mathrm{C}+273=82+273=355^{\circ} \mathrm{K}$

$\mathrm{L}=$ thickness of $\mathrm{PC}, \mathrm{cm}=0.198 \mathrm{~cm}$

$t=$ time to reach $P_{t}$, sec

when $\frac{\mathrm{P}_{t}}{\mathrm{P}_{\infty}}=\frac{7 \times 10^{-8} \mathrm{~atm} \mathrm{cc} \text { tritium/sec }}{2.4 \times 10^{-7} \mathrm{~atm} \text { cc tritium/sec }}=0.29$, then $\frac{\mathrm{Dt}}{\mathrm{L}^{2}}=0.097$

But $D=0.0265 \times \mathrm{e}^{-14,000 /(1.987)(355)}=6.4 \times 10^{-11} \mathrm{~cm}^{2} / \mathrm{sec}$

$$
\therefore t=\frac{(0.097)(0.198)^{2}}{\left(6.4 \times 10^{-11}\right)(3600)(24)}=690 \text { days }
$$

Because it is reasonable to expect the transportation to be completed within 30 days, tritium permeation would be significantly less than the $7 \times 10^{-8} \mathrm{~atm} \mathrm{cc/sec}$.

Other illustrations of these equations and plots are given in references 5,6 , and 7 .

Tritium may be stored in these containers for several years before shipment, but the permeation rate is extremely low under normal storage conditions at less than $100^{\circ} \mathrm{F}$. Calculations indicate that many years must elapse before the permeation rate reaches only $10^{-8} \mathrm{STP} \mathrm{cc} / \mathrm{sec}$, a factor of 10 below the derived maximum allowable limits. Therefore, permeation during normal storage is so small as not to alter the conclusions first drawn. 
Before initial use, each container is leak tested $\left(<7 \times 10^{-8} \mathrm{~atm} \mathrm{cc} / \mathrm{sec}\right)$ at 1.5 times its maximum operating pressure to show that it complies with regulations. Loss through the container valve is also negligible $\left(<10^{-8}\right.$ atm $\mathrm{cc} / \mathrm{sec}$ ) as shown in 3.3.4. Therefore, it is concluded that the LP-50 container does not represent a hazard at the maximum normal operating temperature.

\subsection{Containment Requirements for the}

Hypothetical Accident

\subsubsection{Fission Gas Products}

Not applicable. There are no fission products in the package.

\subsubsection{Release of Contents}

\subsubsection{PC Wall}

Equilibrium hydrogen permeation through type $304 \mathrm{~L}$ SS at $242^{\circ} \mathrm{F}\left(117^{\circ} \mathrm{C}\right)$ is

$1.05 \times 10^{-6} \frac{\mathrm{STP}}{\left(\mathrm{cm}^{2}\right)(\mathrm{hr})}$ at 760 torrs $[3, \mathrm{p} \mathrm{6}]$.

Corrected for pressure, surface area, and wall thickness, the permeation rate becomes:

$\frac{1.05 \times 10^{-6} \mathrm{STP} \mathrm{cc} \mathrm{mm} \times 8040 \mathrm{~cm}^{2}}{(3600 \mathrm{sec} / \mathrm{hr})\left(\mathrm{cm}^{2}\right)(\mathrm{hr}) \times 1.98 \mathrm{~mm}} \sqrt{\frac{31.7}{14.7}}=1.7 \times 10^{-6} \mathrm{~atm} \mathrm{cc} / \mathrm{sec}$

A very long time, however, is required to reach the equilibrium rate. The time to reach $7 \times 10^{-8} \mathrm{~atm} \mathrm{cc} / \mathrm{sec}$ is calculated as shown in 3.2.3.

for $\frac{P_{t}}{P_{\infty}}=\frac{7 \times 10^{-8}}{1.7 \times 10^{-6}} \frac{\text { atm cc tritium/sec }}{a t m c c t r i t i u m / s e c}=0.041$

$$
\frac{D t}{L^{2}}=0.052 \quad \text { from }[3, p 5]
$$


where

$\mathrm{D}=0.0265 \times \mathrm{e}^{-14,000 /(1.987)(390)}=3.8 \times 10^{-10}$

$\mathrm{L} \quad=0.198 \mathrm{~cm}$

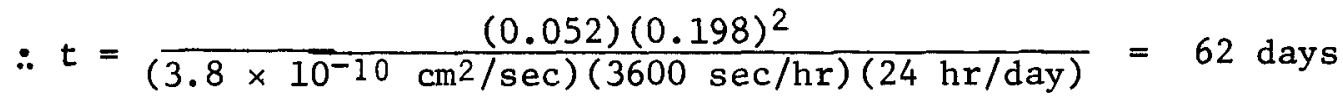

Because the time at the elevated temperature is less than 12 hours, the tritium permeation rate would not reach the limit for even normal shipping conditions.

\subsubsection{PC Valve}

Three slightly different valves are used on the primary containers; the valve shown in figure 7 is typical. Each type was tested for tightness by cycling between $25^{\circ}$ and $110^{\circ} \mathrm{C}$ with the results shown in the following table:

Tritium Leak Rate, ${ }^{a}$ atm cc/sec

\begin{tabular}{|c|c|c|c|}
\hline \multirow{2}{*}{$\begin{array}{l}\text { Tempera- } \\
\text { tures in } \\
\text { Sequence, }{ }^{\circ} \mathrm{C} \\
\end{array}$} & \multicolumn{3}{|c|}{ Valye } \\
\hline & $\begin{array}{c}\text { Fulton } \\
314 \mathrm{~A} \\
\end{array}$ & $\begin{array}{l}\text { Modified } \\
\text { Fulton }\end{array}$ & Hoke \\
\hline 25 & 1.1 & 3.8 & 2.3 \\
\hline 110 & 1.1 & 2.3 & 1.5 \\
\hline 25 & 34 & 1.5 & 3.4 \\
\hline 110 & 29 & 1.9 & 1.9 \\
\hline
\end{tabular}

At $25^{\circ} \mathrm{C}$, leakage from any valve is well below the $7 \times 10^{-8} \mathrm{~atm} \mathrm{cc} / \mathrm{sec}$ limit. At $110^{\circ} \mathrm{C}$, or $82^{\circ} \mathrm{C}$, under normal conditions, leakage is still insignificant, especially when compared to the 1 curie $(0.39 \mathrm{cc})$ loss allowed under accident conditions. [2, section II, para $230(\mathrm{~b})$. 


\subsection{Appendix}

\subsubsection{References}

1. USERDA Manual Chapter 0524, Standards for Radiation Protection.

2. International Atomic Energy Agency (Safety Series No.6) "Regulations for the Safe Transport of Radioactive Materials." 1973 Revised Ed.

3. Jennings, A. S., Composite Reservoir Tests, November 1964, USAEC Report DPSTWD-64-168, E. I. du Pont de Nemours and Co., SRL, A1ken, S. C. 29801. (Secret)

4. Louthan, M. R. and Dexter, A. H., Tritium Offgassing from Pinch Welds, May 1969. USAEC Report DPSTWD-69-131, E. I. du Pont de Nemours and Co., SRL, Aiken, S. C. 29801. (Secret)

5. Flint, P. S., The Diffusion of Hydrogen Through Materials of Construction, December 1951, USAEC Report KAPL-659, Kno11s Atomic Power Laboratory, Schenectady, New York.

6. Rideout, S. P., et. al., Effects of Hydrogen in Metals, June 1966. USAEC Report DPWD-1057 and DPWD-1057TL, E. I. du Pont de Nemours and Co., SRL, A1ken, S. C. 29801. (Secret)

7. Rideout, S. P., et. al., Effects of Hydrogen in Metals - II, December 1967. USAEC Report DPWD-1132 and DPWD-1132TL, E. I. du Pont de Nemours and Co., SRL, Aiken, S. C. 29801. (Secret) 


\subsection{SHIELDING EVALUATION}

4.1 Discussion and Results ................. . . 4-1

4.2 Source Specification ................. . . 4-1

4.3 Model Specification .................. . 44-1

4.4 Shielding Evaluation.................. . . . 4-1

4.5 Appendix . . . . . . . . . . . . . . . . . 4-1 


\subsection{SHIELDING EVALUATION}

It is unnecessary to evaluate shielding for this packaging since the radioactive material (tritium) is a beta emitter and gives off no penetrating radiations.

\subsection{Discussion and Results}

Not applicable.

\subsection{Source Specification}

Not applicable.

\subsection{Model Specification}

Not applicable.

\subsection{Shielding Evaluation}

Not applicable.

\subsection{Appendix}

Not applicable. 


\subsection{CRITICALITY EVALUATION}

5.1 Discussion and Results . . . . . . . . . . . . . . . 5-1

5.2 Fackage Fuel Loading . . . . . . . . . . . . . . . . 5-1

5.3 Model Specification . . . . . . . . . . . . . . . . . 5-1

5.4 Criticality Calculations and Experiments . . . . . . . . . . . 5-1

5.5 Critical Benchmark Experiments . . . . . . . . . . . . . . 5-1

5.6 Appendix . . . . . . . . . . . . . . . . . . . . . 5-1 


\subsection{CRITICALITY EVALUATION}

The radioactive material (tritium) in this package is not fissile and cannot be made to go critical. Therefore, nuclear criticality safety is of no concern in the shipment of this package.

\subsection{Discussion and Results}

Not applicable.

\subsection{Package Fuel Loading}

Not applicable.

\subsection{Mode1 Specification}

Not applicable.

\subsection{Criticality Calculations and Experiments}

Not applicable.

\subsection{Critical Benchmark Experiments}

Not applicable.

\subsection{Appendix}

Not applicable. 


\subsection{OPERATING PROCEDURES}

6.1 Procedure for Loading the LP-50 Package . . . . . . . . . . . 6-1

6.2 Procedure for Unloading the LP-50 Package . . . . . . . . . . . . . 6-1

6.3 Preparation of Empty LP-50 Packaging for Transport . . . . . . . 6-2

6.4 Appendix . . . . . . . . . . . . . . . . . . 6-2

6.4.1 References ..................... 6-2

6.4 .2 Labels ........................ . . 6-3 


\subsection{OPERATING PROCEDURES}

Definition of Terms

The LP-50 tritium packaging is composed of three major parts:

1. A product container (PC) which is a stalnless steel vessel into which tritium is loaded.

2. A shell which is an aluminum inner container into which a product container is placed.

3. An insulated shipping drum or overpack which is a carbon steel drum with a lid and locking ring; it contains a PC inside a shell surruunded with insulation.

\subsection{Procedure for Loading the LP-50 Package}

Loading of the LP-50 container is performed per DPSOL 232-H-804 [1]. An LP-50 PC is selected for loading. (Each PC has been previously removed from an insulated shipping drum and has been verified to be empty.) In a protective hood, the aluminum cover is removed from the shell and the PC is exposed. The $P C$ is inspected for matching serial numbers, visual damage, and type of valve. The PC is evacuated and a rate of rise determination is made at 50 microns of pressure to determine the presence of water or inleakage. The rate of rise must be less than 1 micron per 10 minutes.

The PC is loaded to a maximum of 1200 torrs. The PC valve is determined to be closed by a rate of rise pressure test. (A rise of 8 microns of pressure or less over 20 minutes at 20 microns.) The loaded PC is removed from the loading station and a compression cap with a gasket is installed on the fill valve. After the PC is decontaminated and the serial number is matched with the shell, the PC'is placed in its shell. The PC is again monitored for tritium which must be less than $8 \times 10^{-5}$ microcuries/cc. A lead seal is attached to the valve and compression cap. The cover of the shell is bolted in place, after the rubber 0-ring and groove are verified to be in good condition. Lead seals are installed through two of the bolts, $180^{\circ}$ apart. The shell is decontaminated to less than $500 \mathrm{c} / \mathrm{m} / 100 \mathrm{~cm}^{2} \beta-\gamma$. The shell vent valve is closed and sealed using a numbered aluminum tag and a lead seal. The open pipe is capped with a pipe cap. DPSOL 232-H-114 [2] is used, verifying that the PC in the shell is loaded and ready to be placed in an LP-50 overpack shipping drum.

The shipping drum is opened and inspected for significant defects or damage. The sealed PC shell containing the PC is placed in the overpack. The insulation cover is installed. A thin disk of insulation is placed on the cover. The drum lid is secured with a bolted locking ring and a lead seal. The overpack is labeled with two Military shipment labels (Form DD 1387) [see 6.4.2] and two Radioactive Yellow II labels (Form AEC 209). The sealed overpack is decontaminated to less than $150 \mathrm{~d} / \mathrm{m} / 100 \mathrm{~cm}^{2} \beta-\gamma$. DPSOL 232-H-114 [2] is completed, 
recording the drum serial number, the PC number, and verifying that the shipment has been prepared in compliance with procedures.

The shipment is transfered to the ERDA with Courier Receipt, ERDA 60 [sec 6.4.2] as a record.

These methods provide effective control and have been in use for several hundred shipments during the past decade.

\subsection{Procedure for Unloading the LP-50 Package}

The overpack is received from ERDA using DPSOL 232-H-208 [3]. The overpack is monitored for radioactivity. The locking ring bolt seal is broken and the drum lid and top insulation are removed. The PC and shell are removed and inspected for proper seals ( $180^{\circ}$ apart on lid bolts and shell vent valve) and any obvious damage. The PC is placed in a protective hood and is unloaded per DPSOL 232-H-806 [4] or 232-H-813 [5].

\subsection{Preparation of Empty LP-50 Packaging for Transport}

An empty contaminated LP-50 PC is prepared and transported in a manner identical to that for a loaded PC. Residual radioactive gas is always present from outgassing from the container walls. An "empty" tag is attached to the: handle of the LP-50 she11.

\subsection{Appendix}

\subsubsection{References}

1. DPSOL 232-H-804, Loading Product Container LP-50

2. DPSOL 232-H-114, LP-50 Loading/Shipping Verification

3. DPSOL 232-H-208, Receiving LP-12 and LP-50 Product Containers

4. DPSOL 232-H-806, Unloading Product Container LP-50 on the PL Flange

5. DPSOL 232-H-813, Unloading Product Container LP-50 on the TS Flange

6. DPSOL 232-H-1414, Pressure and Leaktesting Product Containers LP-12 and LP-50

7. DPSOL 232-H-1544, Cleaning Interior of Product Containers

8. DPSOL 232-H-1540, Preparing Product Containers for Repair

9. DPSOL 232-H-113, Certification of Pressure Test - Product Containers

10. DPSOL 232-H-8566, Welding Product Containers 
The following additional operating procedures are referred to in the procedures just 1isted.

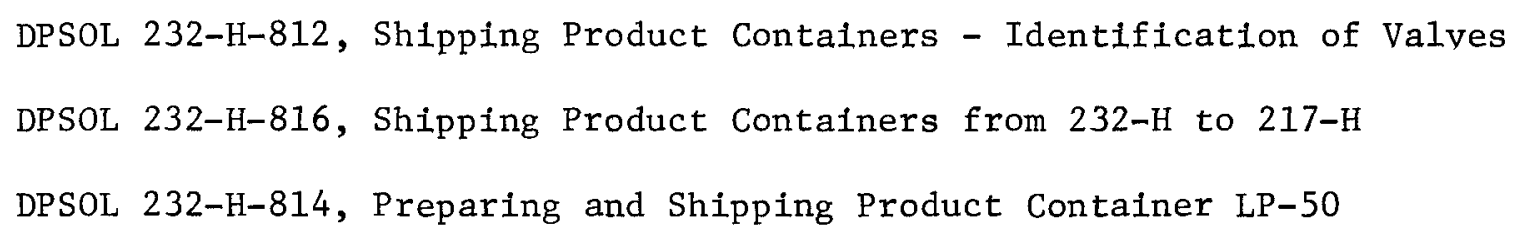

6.4.2 Labels

Form DD $1387 \quad$ Military Sh1pment Labe1

AEC-60 Courier Receipt 
7.1 Acceptance Tests . . . . . . . . . . . . . . . . . 7-1

7.1.1 Visual Inspection ................... . . 7-1

7.1 .3 Leak Testing .................... . . 7-1

7.1 .4 Valves ........................ . . . . . . . . . . . .

7.1.5 Test for Shielding Integrity . . . . . . . . . . . . 7-1

7.1.6 Thermal Acceptance Test . . . . . . . . . . . . 7-2

7.2 Maintenance Program . . . . . . . . . . . . . . . 7-2

7.2.1 Structura1 and Pressure Test ............ 7-2

7.2.2 Leak Tests .................... . 7-2

7.2.3 Valve Replacement . . . . . . . . . . . . . . 7-2

7.2 .4 Miscellaneous . . . . . . . . . . . . . . . 7-2 


\section{$\underline{7.1 \text { Acceptance Tests }}$}

\subsubsection{Visual Inspection}

The PC is inspected for bulges, dents, mars, or other obvious physical defects on receipt at the plant. The inside is flushed with Freon ${ }^{\circledR}$ and alcohol to verify the cleanliness of the container.

The shipping packaging is inspected for obyious damage. The insulation is visually checked for voids or cracks. The PC is dimensionally checked by fitting it in a shell.

\subsubsection{Structural and Pressure Tests}

Each PC is pneumatically tested at 1.5 times loading pressure. The concavity of the bottom is verified to be within specifications and that no permanent deformation is indicated.

\subsubsection{Leak Testing}

Each PC is leak tested with helium. Leak testing is performed per DPSOL 232H-14].4(6.4.1[6]). A leak rate of $7 \times 10^{-8} \mathrm{~atm} \mathrm{cc} / \mathrm{sec}$ or less is acceptable. The maximum leakage of the shell under vacuum is verified to be less than 0.1 micron $\mathrm{ft}^{3} / \mathrm{hr}$ or $1 \times 10^{-6}$ atm $\mathrm{cc} / \mathrm{sec}$.

\subsubsection{Valves}

Valves are checked for operability and are leak tested during the tests noted in section 7.1.3.

\subsubsection{Test for Shielding Integrtty}

Not applicable. No penetrating radiation is present.

1 Du Pont trademark. 


\subsubsection{Thermal Acceptance Test}

The maximum temperature of the product containers is estimated at $177^{\circ} \mathrm{F}$ when in equilibrium with the shipping drum during the most severe environmental conditions $\left(130^{\circ} \mathrm{F}\right.$ and full sunlight). This is considerably below the threshold temperature of $285^{\circ} \mathrm{F}$, above which significant breakdown of Celotex ${ }^{\circledR}$ insulation occurs. Therefore no further thermal testing is necessary.

Samples of the Celotex ${ }^{\circledR}$ insulation of the existing shipping drum overpacks indicate that the material is acceptable.

\subsection{Maintenance Program}

\subsubsection{Structural and Pressure Tests}

The PC is structurally tested by eyacuation prior to each loading. The vacuum is measured using a thermocouple vacuum gage which is accurate to \pm 10 microns.

\subsubsection{Leak Tests}

The PC is leak tested at the same time it is vacuum tested, prior to each loading. The leak rate must be less than 1 micron per 10 minutes at 250 microns or less.

\subsubsection{Valve Replacement}

The closure valve for the PC is replaced when it no longer provides an effective seal or is stuck. The defective valve is removed. The container is flushed to remove any particulate matter per DPSOL 232-H-1544(6.4.1[7]) and a new valve is installed per DPSOL 232-H-8566 (6.4.1[10]) or 232-H-1540(6.4.1[8]). The PC is then retested per DPSOL 232-H-1414 (6.4.1[6]).

\section{$\underline{7.2 .4 \text { Miscellaneous }}$}

The PC she11 and shipping drum are visually inspected prior to each use for obvious physical damage. The insulation is inspected for excessive moisture before the PC is installed in its shell.

The gasket in the PC valve compression plug is replaced after each loading.

The 0-ring for the shell is inspected prior to each use and replaced as necessary. 


\subsection{QUALITY ASSURANCE REQUIREMENTS}

8.1 Organization . . . . . . . . . . . . . . . . . 8-1

8.1.1 Personne1 ...................... . . 8-1

Organization Chart ................. 8-2

8.2 Quality Assurance Program . . . . . . . . . . . . . . 8-1

8.2.1 Procedures ..................... . . 8-1

8.2.2 Approval ........................ . 8-1

8.2.3 Safety Related Items . . . . . . . . . . . . . 8-1

8.2.4 Tralning . . . . . . . . . . . . . . . . 8-1

8.3 Design Review .. . . . . . . . . . . . . . . . 8-3

8.4 Procurement Document Contro1 . . . . . . . . . . . . . 8-3

8.5 Instructions, Procedures, and Drawings . . . . . . . . . . 8-3

8.6 Document Control .. . . . . . . . . . . . . . . . 8 8-3

8.7 Control of Purchased Materla1, Equipment, and Services . . . . . 8-3

8.8 Identification and Control of Materials, Parts, and Components . . 8-4

8.9 Control of Spectal Processes . . . . . . . . . . . . . . . 8-4

8.10 Inspection . . . . . . . . . . . . . . . . . . . . . 8-4

8.11 Test Control . . . . . . . . . . . . . . . . . 8-4

8.11.1 Preoperational Test Program ............... . 8-4

8.11.2 Acceptance Tests and Maintenance Program . . . . . . . 8-5

8.12 Control of Measuring and Test Equipment . . . . . . . . . . 8-5

8.12.1 Calibration ................... . . 8-5

8.12.2 Primary Standards . . . . . . . . . . . . 8-5

8.13 Handling, Storage, and Shipping ............... . 8-6

8.14 Inspection, Test and Operating Status . . . . . . . . . 8-6

8.15 Nonconforming Material, Parts, or Components . . . . . . . 8-6

8.15.1 Disposition . . . . . . . . . . ....... . 8-6

8.15.2 Acceptance ................... . . 8-6

8.16 Corrective Action ..................... . 8-6

8.17 Quality Assurance Records . . . . . . . . . . . . . . 8-7

8.18 Audits. . . . . . . . . . . . . . . . . . . 8-7

8.18.1 Monthly . . . . . . . . . . . . . . . . . 8-7

8.18.2 Semiannual . . . . . . . . . . . . . . . 8-7

8.19 Reference . . . . . . . . . . . . . . . . . . 8-7

8.19.1 Specification . . . . . . . . . . . . . 8-7 


\subsection{QUALITY ASSURANCE REQUIREMENTS}

\subsection{Organization}

Separations production management is responsible for quality assurance of the shipping packaging. Quality assurance in the Atomic Energy Division of E. I. du Pont de Nemours and Co. is an integral part of the design-fabricationoperational system. This provides a system of checks at all organizational levels that ensures the work produced by any group is scrutinized by other groups over which the producing group has no contro1.

\subsubsection{Personne1}

Personnel in the groups, on the organization chart, draw on long experience and are specialists in their respective fields. See chart on p 8-2.

\subsection{Quality Assurance Program}

\subsubsection{Procedures}

Written Quality Assurance (QA) procedures for the design and fabrication of the LP-50 packaging are not available, as this packaging was constructed over a decade ago (8.3 and 8.4). Quality Assurance is incorporated in the operating and maintenance procedures (chapters 6 and 7 ).

\subsubsection{Approval}

Quality Assurance functions are incorporated in the operating procedures (chapter 6). The procedures are reviewed and approved by Production and Technical supervision through the plant staff level (department superintendents).

\subsubsection{Safety Related Items}

Safety related or "Q items" are the product container, the overpack insulation, and the 18 gage shipping drum. The aluminum she11 is a "non-Q item."

\subsubsection{Training}

Personnel are trained by Production supervision using approved operating procedures. An Operator Training Status book is maintained for each operator in the unit. The training status is continually updated. As procedure revisions are issued and reviewed with the operator, the status book is dated and initialed. A computer callout provides for semiannual review of the tratning status of each operator. 


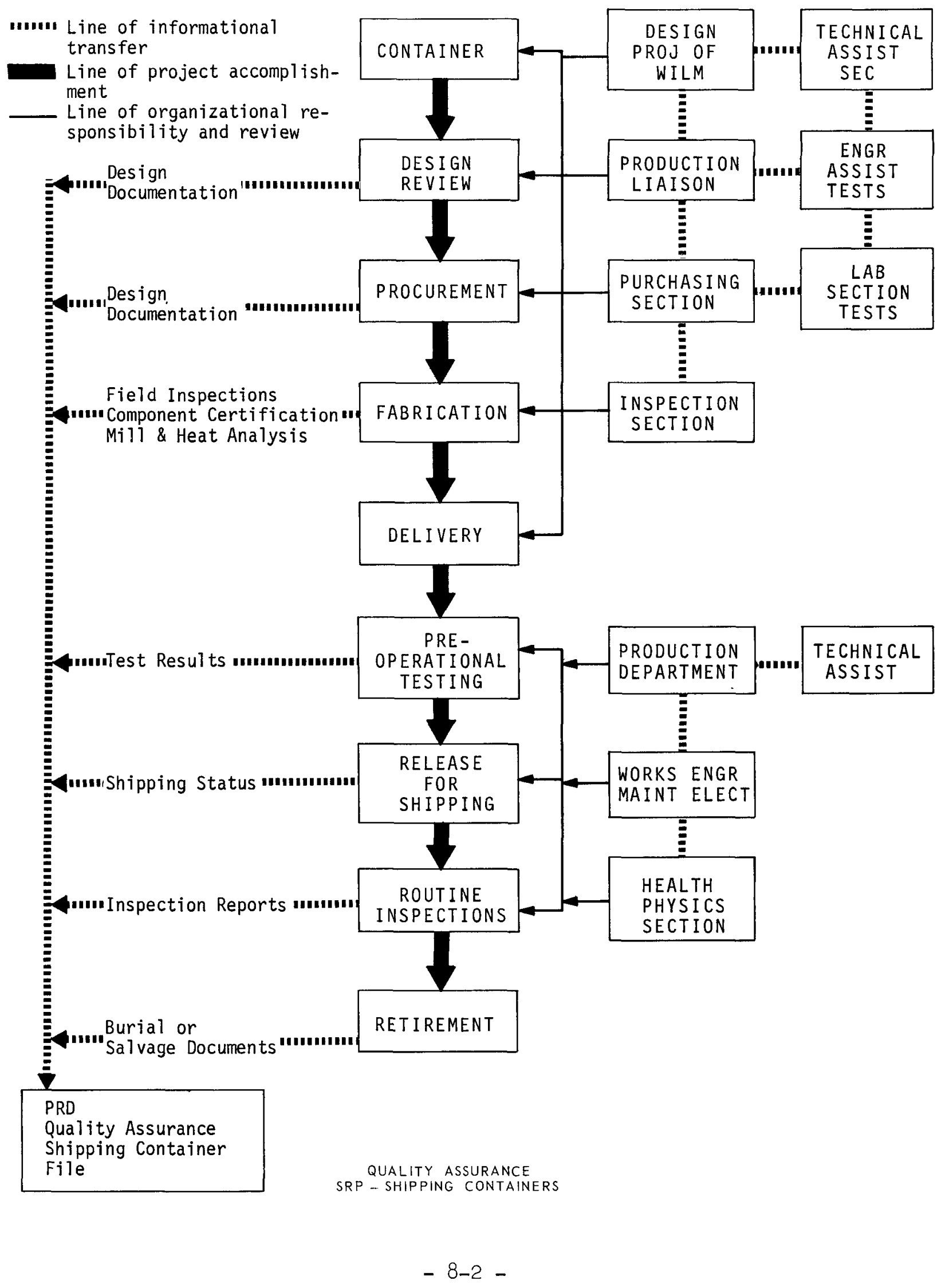




\subsection{Design Review}

This subsection is not applicable for the LP-50 packaging. The subject packaging was designed, fabricated, and has been in service for over a decade. Design interfaces and design audits at this time would be inappropriate.

\subsection{Procurement Document Control}

Procurement of the LP-50 packaging was completed over a decade ago. Available documentation and product verification tests have been placed in the Quality Assurance Record file. Future purchase of LP-50 shipping packages will be done following the guidelines specified in Du Pont Specification No. 5999. (See 8.1.9.1.)

\subsection{Instructions, Procedures, and Drawings}

A11 production and maintenance work with shipping and packaging is performed in strict accordance with written operating procedures or DPSOLs. Activities that affect the quality of the shipment are certified on "use every time" DPSOLs or certification sheets.

Refer to chapter 6, Operating Procedures, for specific information relating to the procedures governing activities with this packaging.

\subsection{Document Contro1}

Operating procedures and drawings are given independent reviews by two levels of Production supervision and two levels of Technical Assistance personnel. The reviewers are thoroughly trained that Quality Assurance is an integral part of the design, construction, and operations at the Savannah River Plant.

Documents to be controlled are plant drawings and procedures. Drawing changes must be approved by Production, Technical Assistance, and Works Engineering personnel. The Plant Records Division maintains a file of the latest revisions. The Plant Drawing Schedule reflects the latest revision number; this schedule is updated at least every two months or as required. Newly revised procedures are placed in working master procedure files as received. The working master files are compared to the master procedure file on a periodic basis by computer callout tickler.

\subsection{Control of Purchased Material, Equipment, and Services}

Procurement of the LP-50 packaging was completed over a decade ago. Inspections and tests have been performed on a random sample of the existing containers. Items tested were: dimensional verification, spectrographic analysis of metal used for fabrication, densities of insulation, and verification that the drums were fabricated per Military specifications. The result of these inspections and tests have been included in the Quality Assurance record file. 
Future purchases will be made in accordance with Du Pont Specification No. 5999.

\author{
8.8 Identification and Control of Materials, \\ Parts, and Components
}

Procurement of the LP-50 packaging was completed over a decade ago. Verification of material used in the LP-50 packaging is listed in section 8.7. Future packaging purchases will be made per Du Pont Specification No. 5999 which requires that mill test reports and certification of components be kept in the Quality Assurance record file.

\title{
8.9 Control of Spectal Processes
}

Fabrication of the LP-50 packaging was completed over a decade ago. The manufacturer of the product container and shell is no longer in business. Nondestructive physical testing of the PC ensures that the welding meets the needs of this container. The manufacturer of the steel drums has certified that fabrication was per Military specifications, except as specified on the drawing.

\subsection{Inspection}

Inspection activities for future procurement of LP-50 shipping packaging will follow the guideline specified in Du Pont Specification No. 5999. This specification indicates mandatory inspection holdpoints, inspection records, welding data, and other pertinent tests required to ensure quality.

\subsection{Test Contro1}

\subsubsection{Preoperationa1 Test Program}

Preoperattonal tests of each product container are described in DPSOL 232-H-1414 (6.4.1 [6]). The tests are certified by the packaging supervisor on a certification sheet, DPSOL 232-H-113 (6.4.1, [9]). The certification sheet is kept on permanent file for the life of the container. The pressure test is continously valid unless the PC is damaged or altered. The packaging supervisor is responsible for the preparation and testing of new PC's.

The procedures used for testing were prepared by a procedures group. The procedures are reviewed and approved by both Production and Technical management to the Plant staff level. 


\subsubsection{Acceptance Tests and Maintenance Program}

Initially, the PC is physically inspected for damage and pertinent physical dimensions. The valve is verified to be the proper type and correctly installed. The PC is pneumatically tested at 1.5 times operating pressure. The PC is evacuated, then pressurized with helium to 415-440 torrs. The PC is sealed and placed in a vacuum chamber. A hellum leak test is made. The leak test is acceptable if the detectable helium is $7 \times 10^{-8} \mathrm{~atm} \mathrm{cc} / \mathrm{sec}$ or less less. The date of the test 1s engraved on the PC per DPSOL 232-H-1414 $(6.4 .1[6])$.

A test is made of the PC prior to each use. The PC is inspected for obvious physical damage, the serial numbers are verified to be in agreement, and the valve is determined to be in working order. The PC is vacuum tested for leakage of 1 micron or less in 10 minutes at 250 microns or less per DPSOL 232-H$804(6.4 .1[1])$.

\subsection{Control of Measuring and Test Equipment}

\subsubsection{Calibration}

Pressure gages and pressure transducers used during loading and proof testing are standardized with a mercury manometer prior to each use.

Helium leak detectors are calibrated with a "standard" leak each time the detector is used.

\subsubsection{Primary Standards}

The pressure transducers are caltbrated using a mercury manometer tester on an annual basis. The welghts for the dead weight tester are callbrated at the Savannah River Standards Laboratory using weights that are matched to the National Bureau of Standards.

The standard hellum leak is callbrated vs. a known leak. The known leak is calibrated by PVT determinations with a certifled leak supplied by Sandia Laboratory. (Sandia Laboratory supplies certifled leaks 'for ERDA.)

\subsection{Handling, Storage, and Shipping}

The written operating procedures in section 6.4 cover the handling and storage of LP-50 packaging components. The PC in shells are stored inside plant buildings in regulated areas or in locked vaults, depending on the product content.

Shipment of LP-50 packages is by ERDA truck under the supervision of ERDA couriers. 


\subsection{Inspection, Test, and Operating Status}

Each PC and shell is inspected on recelpt for obvious damage and proper dimensions. Then the inside of the PC is clean with Freon ${ }^{\circledR}$ and alcohol. The Freon ${ }^{\circledR}$ is tested for contamination and oil per DPSOL 232-H-1544 (6.4.1[7]).

The PC is pneumatically tested at 1.5 times operating pressure. The PC is evacuated and then pressurized with helium to 1115-1170 torrs. The sealed PC is placed in a vacuum chamber. The chamber is sealed and evacuated with a helium leak detector pump. The leak test is acceptable if detectable helium is $7 \times 10^{-8} \mathrm{~atm} \mathrm{cc} / \mathrm{sec}$ or less. This work is done per DPSOL 232-H-1414 (6.4.1[6]). Certiftcation form DPSOL 232-H-113 (6.4.1[9]). Is completed and kept on file as long as the packaging is in use.

The PC, the she11, and the lid are engrayed with the date of the test and the model number.

The operating status of a PC and shell is recorded on a tag attached to the handle of the shell as noted in the operating and testing DPSOLs.

\subsection{Nonconforming Material, Parts, or Components}

\subsubsection{Disposition}

Damaged or nonconforming containers are tagged as listed in section 6.4. A tag is attached to the shell handle. The PC and shell are moved to a segregated storage area.

The maintenance coordinator is notified of the nonconforming container. The coordinator is responsible for the repair and/or disposal of nonconforming containers.

\subsubsection{Acceptance}

No matertal is accepted from a yendor if it is known to be nonconforming.

\subsection{Corrective Action}

Operating personnel report the damage or nonconformance of a PC or shell to supervision. Operating supervision notifies the maintenance coordinator who directs the specific action to be taken: a) repair, or b) ensure that the PC is empty prior to disposal by burial. 


\subsection{Quality Assurance Records}

Records are kept in the Plant Records Division (PRD) Quality Assurance ShIPping Container file.

\subsection{Audits}

\subsubsection{Monthly}

Audits are conducted monthly by first-and second-line supervision. The senior supervisor leads an audit team. The team is to audit procedures and practices in the facility. A report of the audit is submitted to supervision of the facility.

\subsubsection{Semiannual}

Audits are conducted semiannually by an area supervisor and an area superintendent. The area superintendent is the group leader. This group is from plant facilities other than the facility under audit. The group submits a written report to the Department Superintendent.

\subsection{Reference}

\subsubsection{Spectfication}

1. Du Pont Specification No. 5999, "Preparation of Purchase Specifications for Radioactive Material Shipping Containers." 


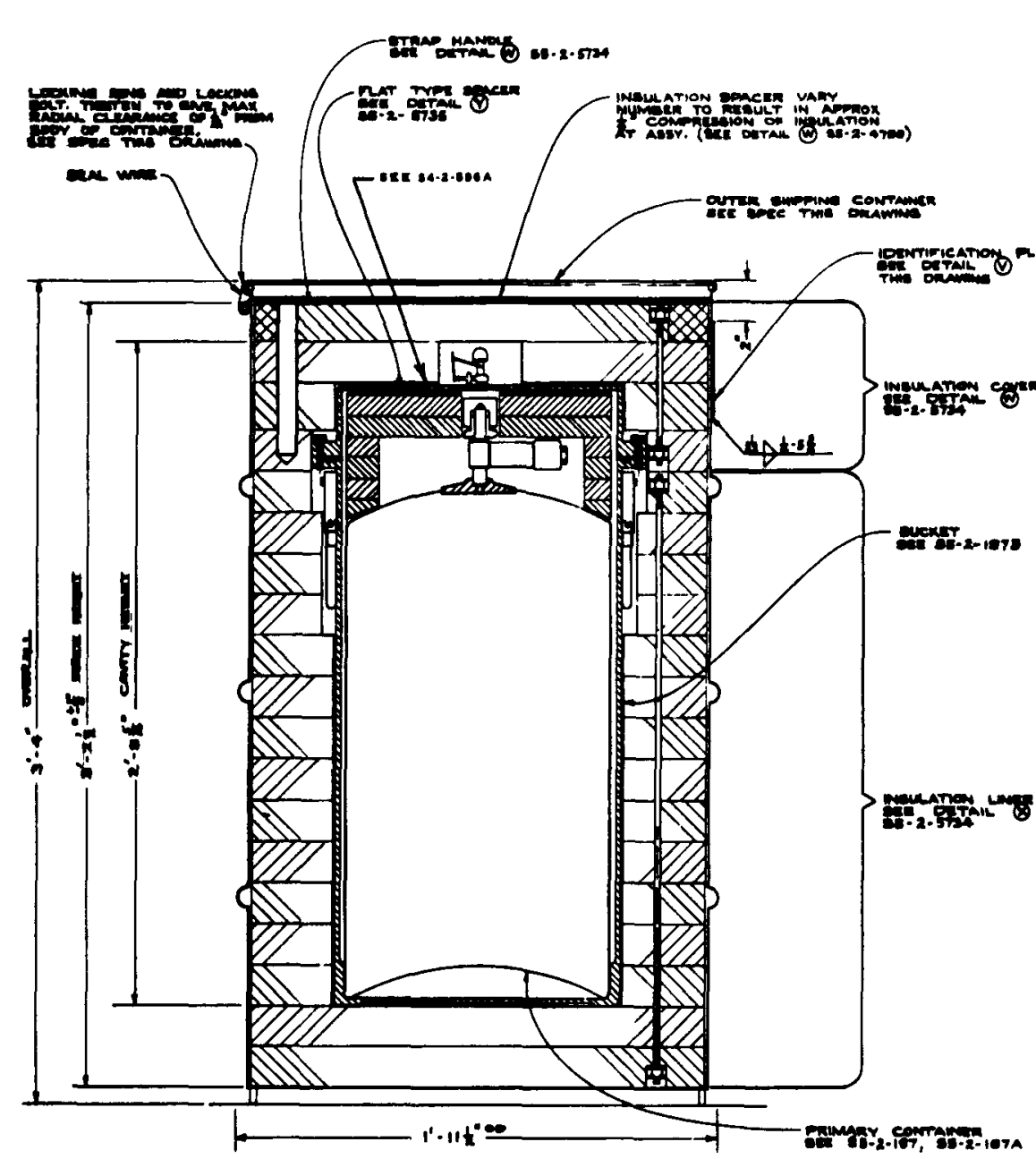

ELAT-TYPE ARRANGEMENT

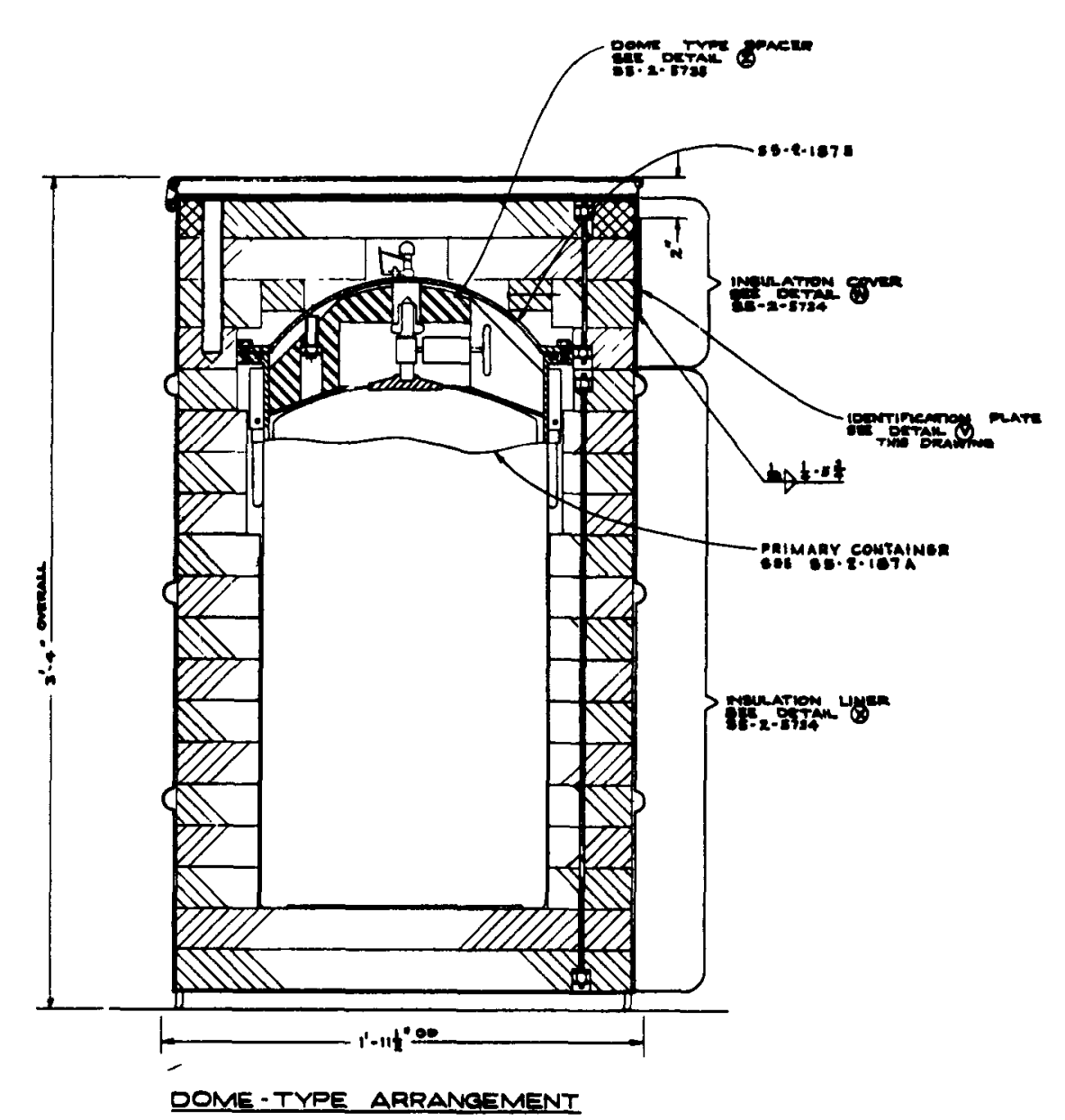

DOME-TYPE ARRANGEMENT

OUTER SHIPPNO CONTAINER LP. SO SPECIRICATION

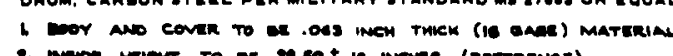

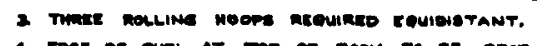

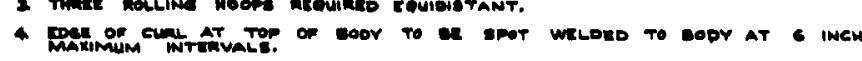

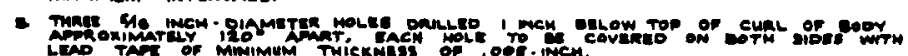

- cocking

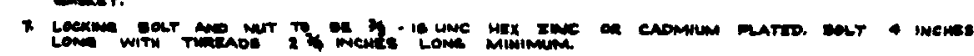

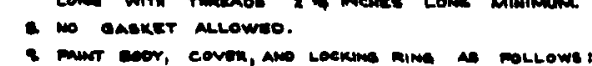

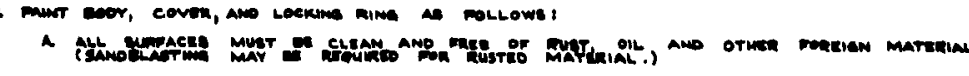

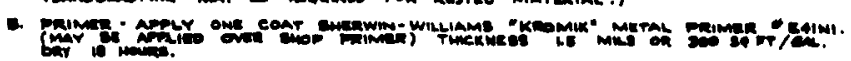

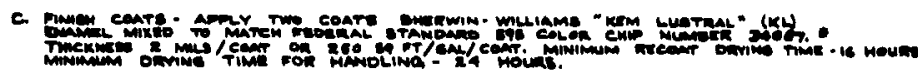

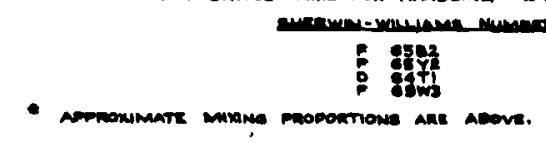

施

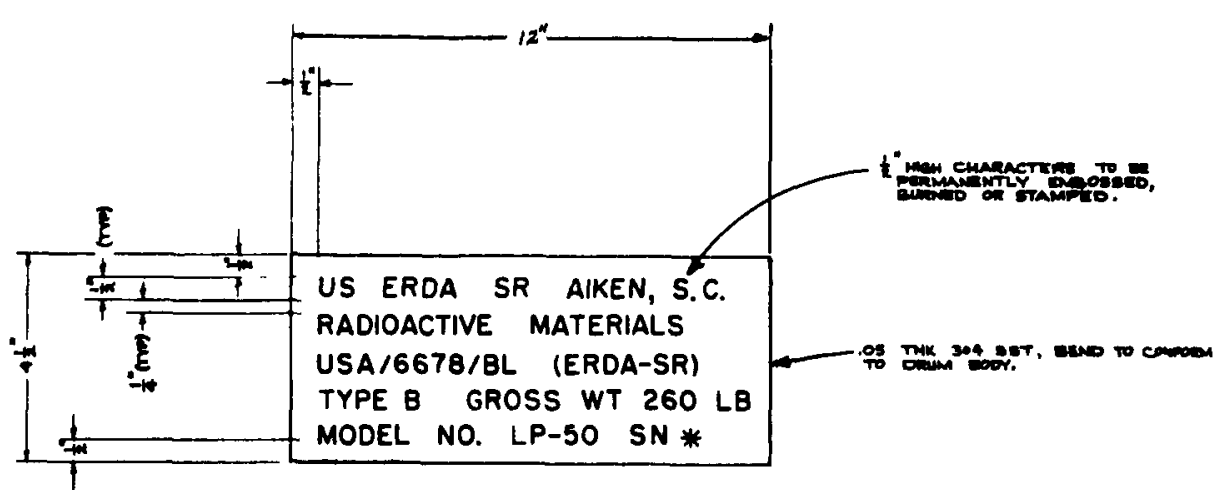

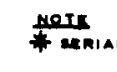

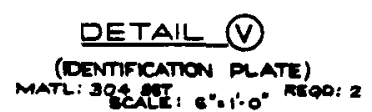

GENERAL NOTES:

1) 

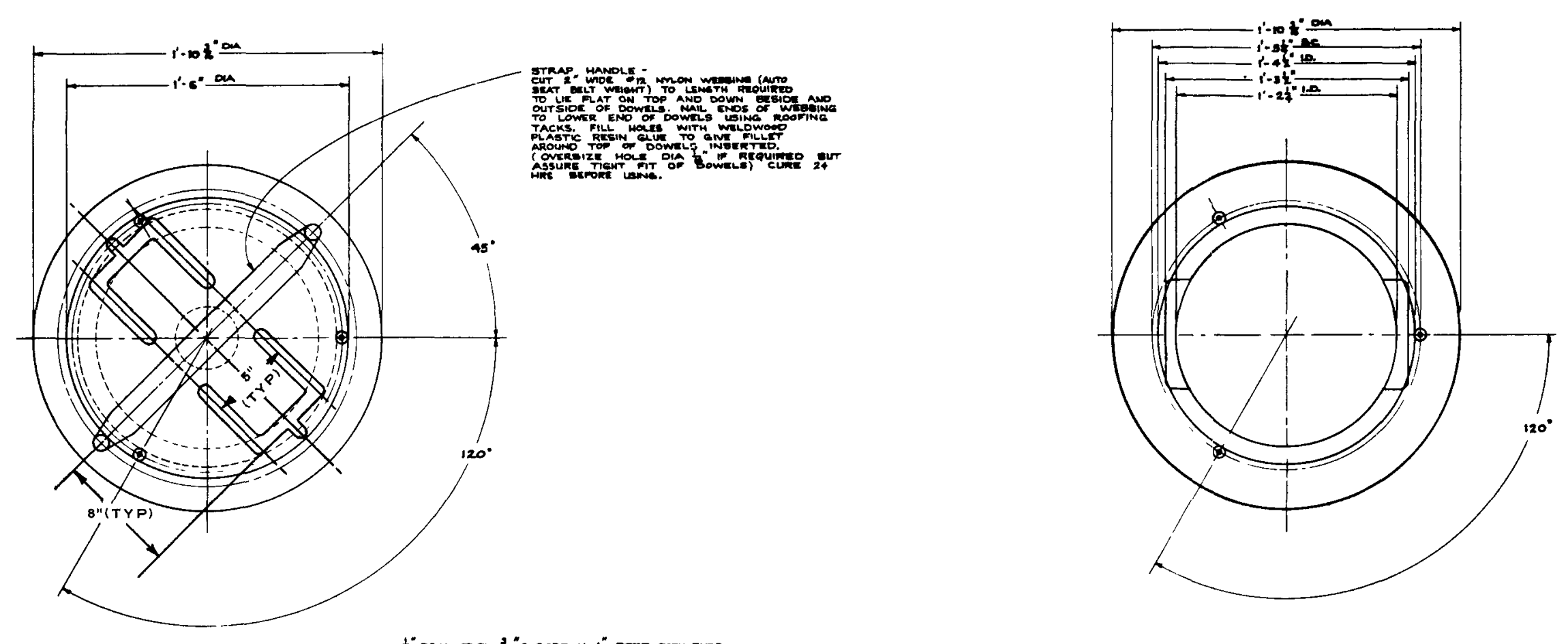

GENERAL NOTES:

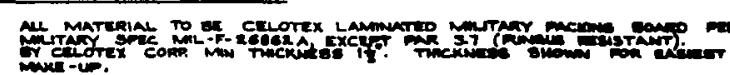

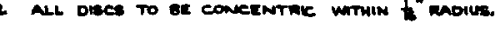

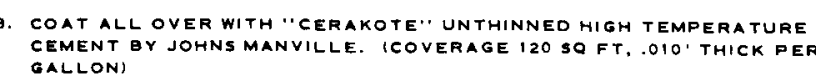

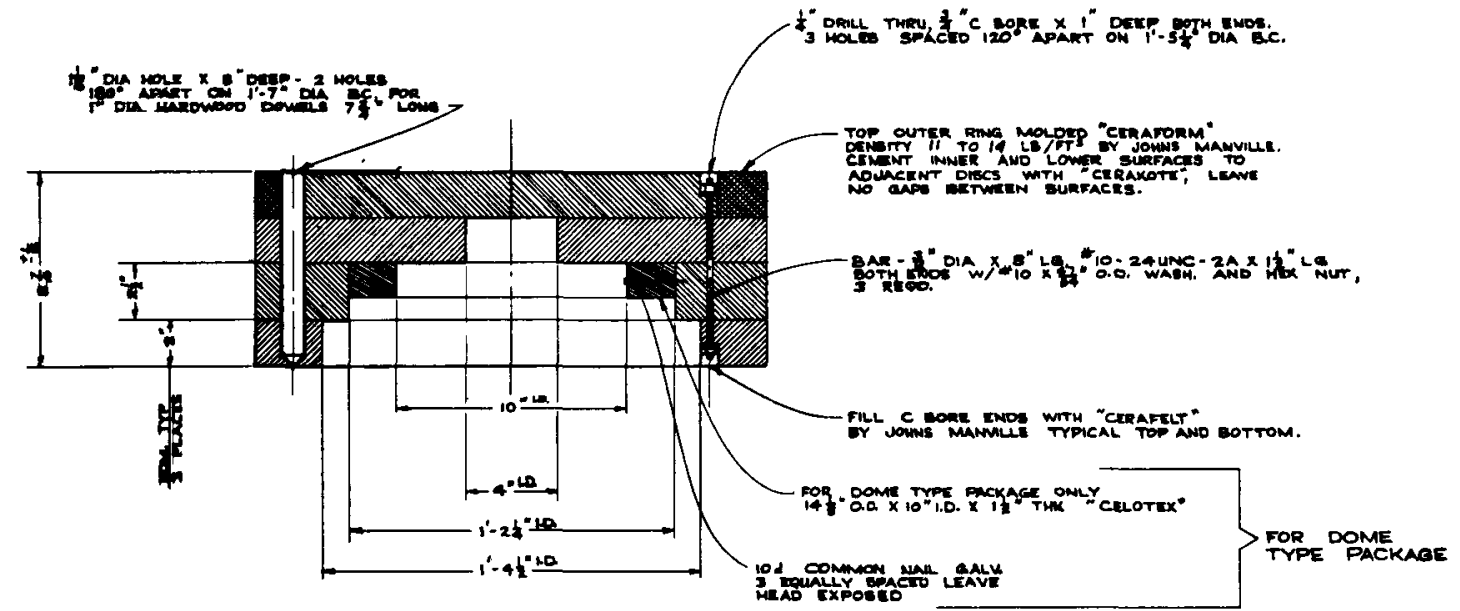

DETAIL (N) (35-2-572)

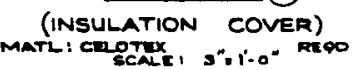

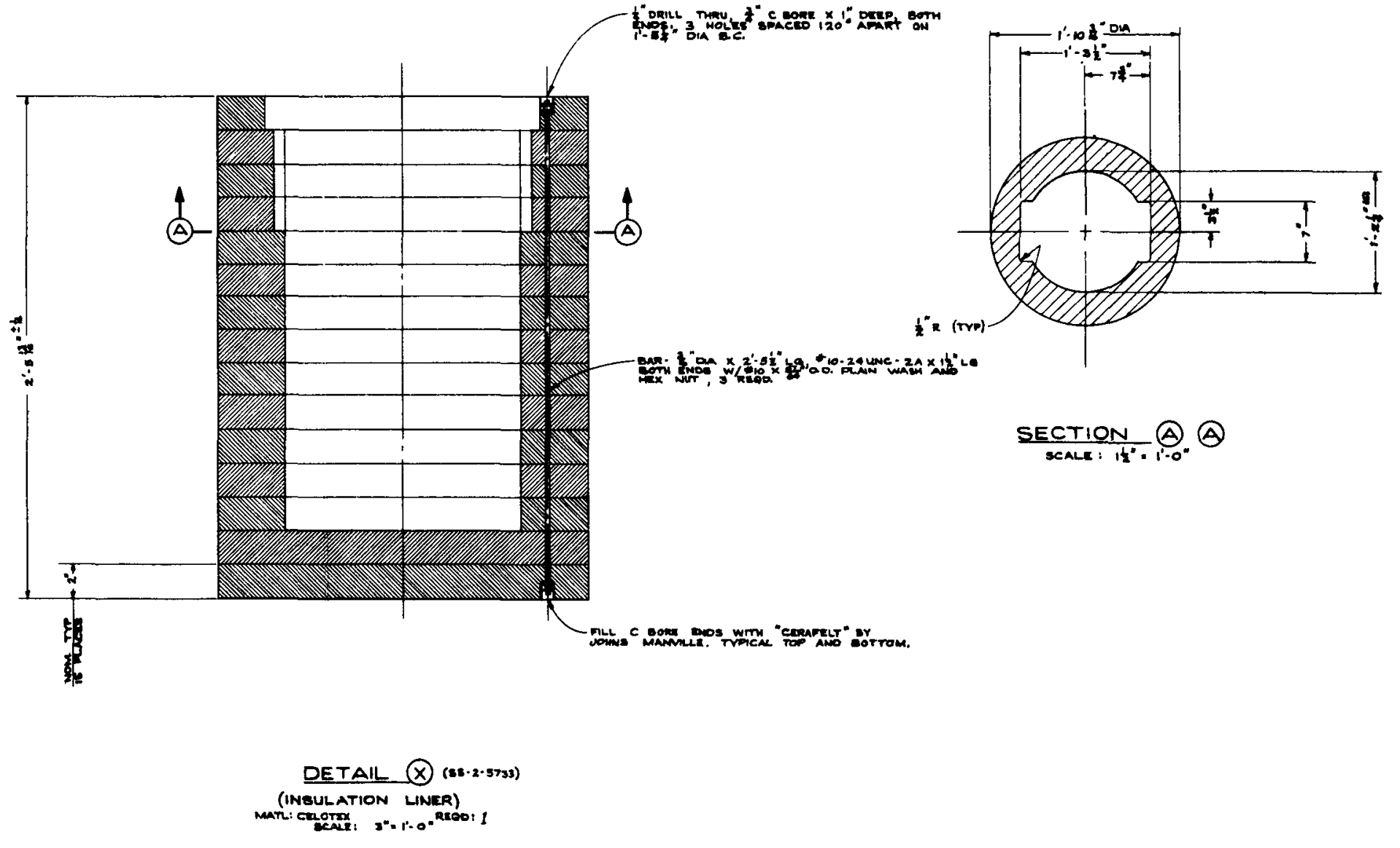



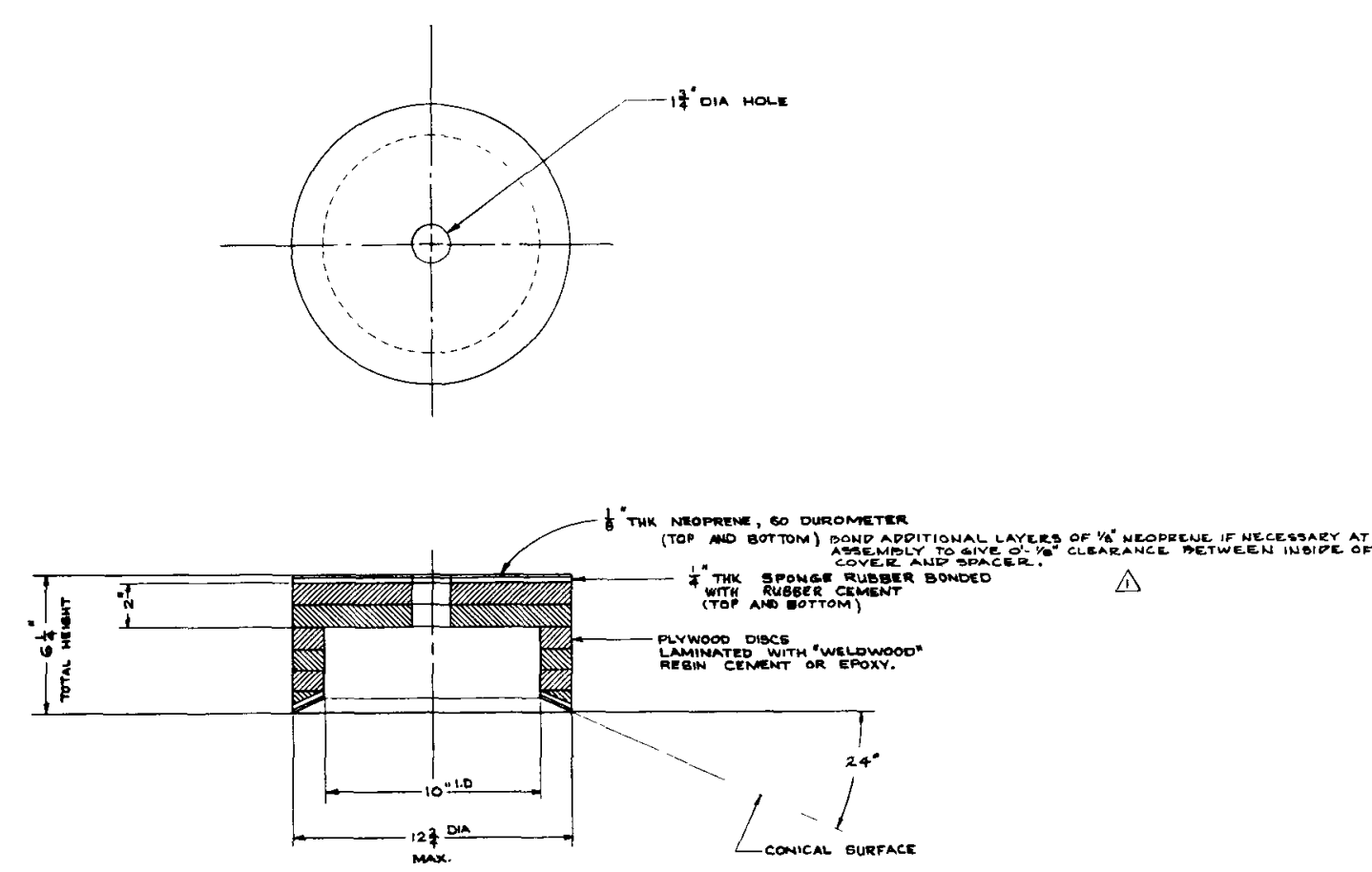

NOTE:

DETAIL (1) (s5:-2:53:)

MFLAT TYLE SPAER)

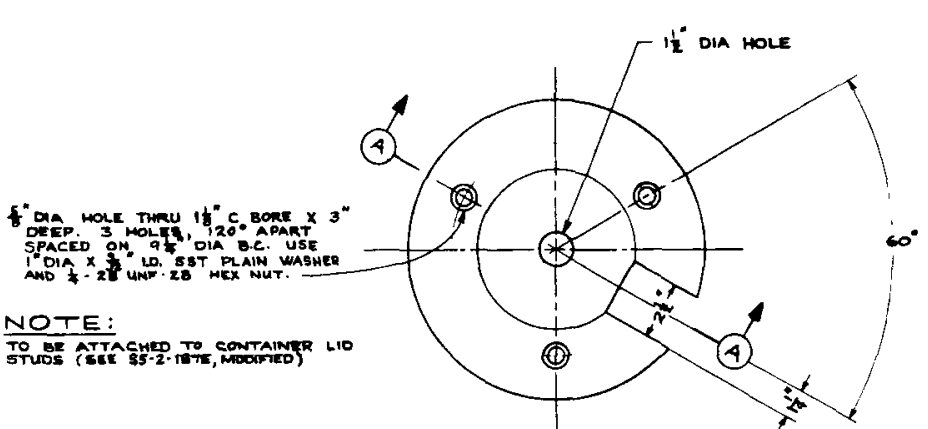

BOTTOM MEW

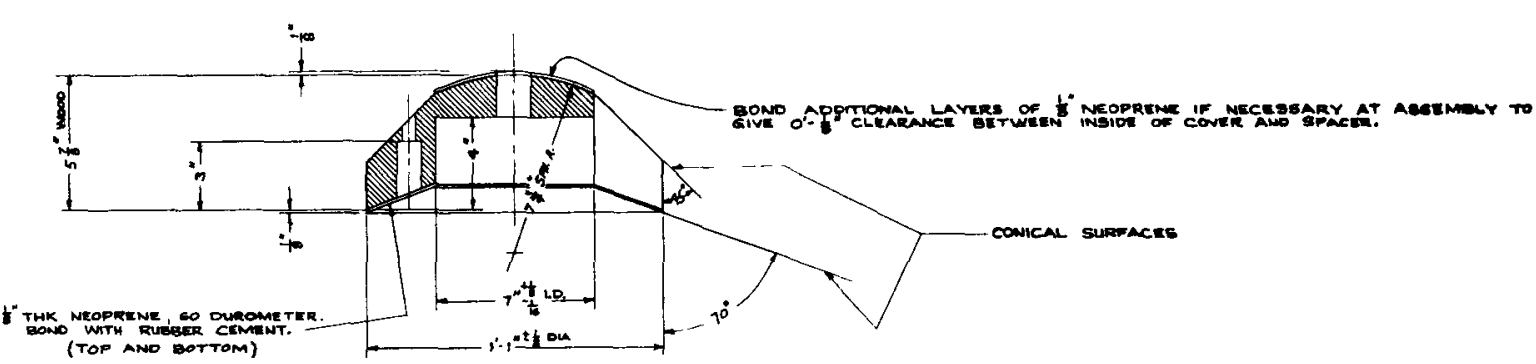

SECTION (A) (A)

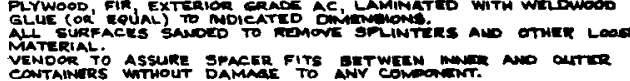

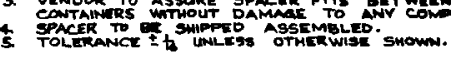

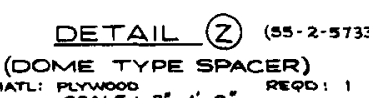



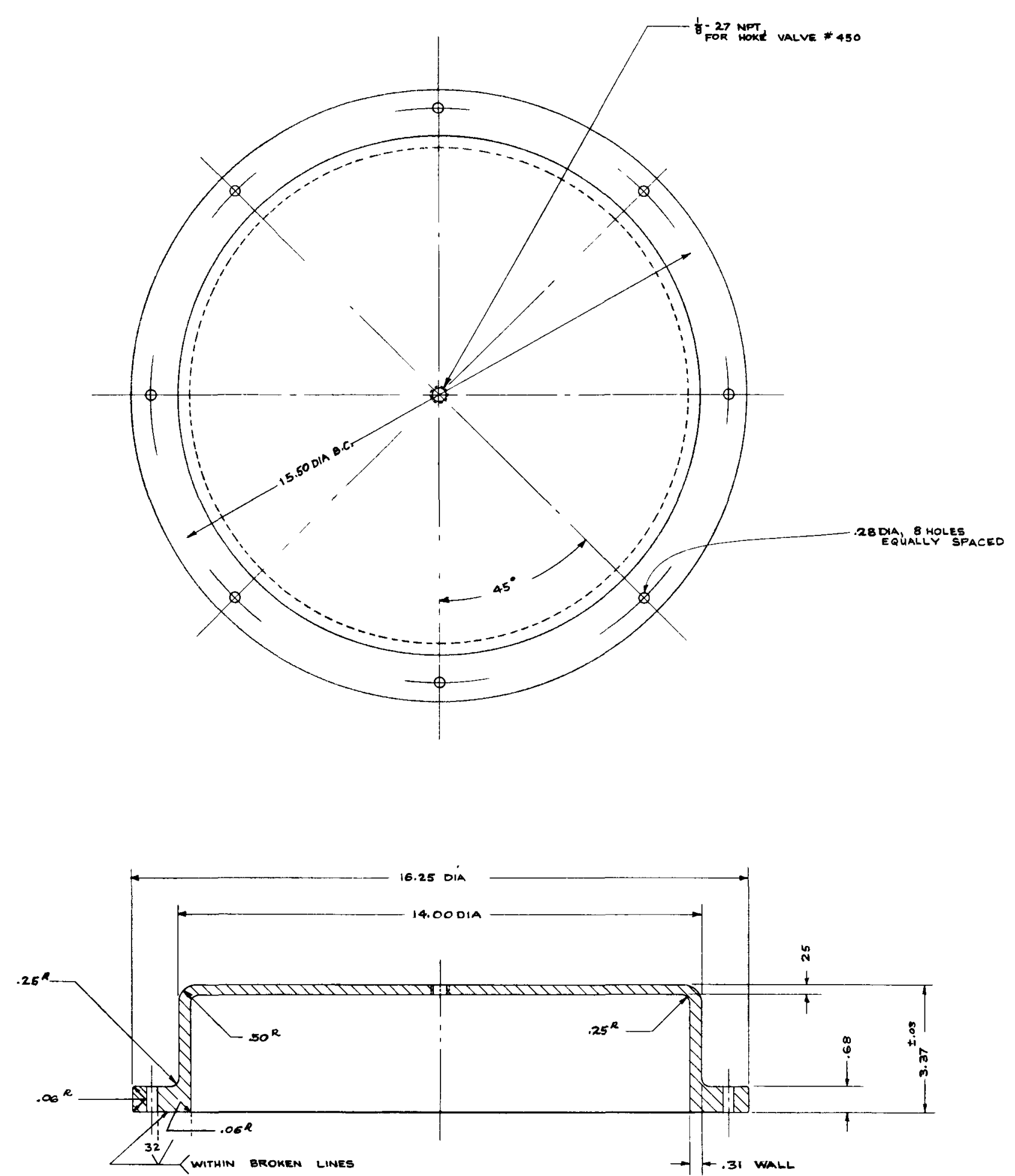

\section{GENERAL NOTES}

2. NORMARRALL TO BE ALLUMINUM ALLOY 356 -T6, AND FREE OF AIR HOLES.

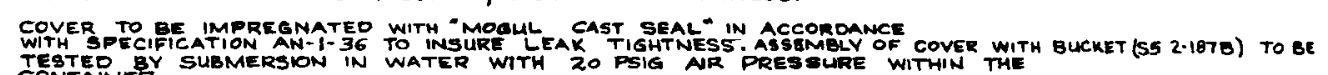
4. REMOVE ALL BurRs AND greak ALL SHARP EDGes.

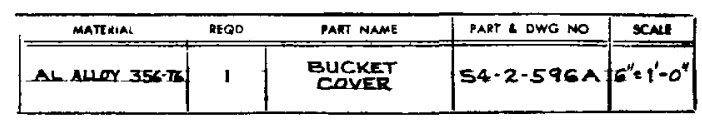

FIGURE 3B. LP.50 SHIPPING CONTAINER PACKAgING - BUCKET COVER (Du Pont dwg \$4-2.596, Rev 0, July 1972) 


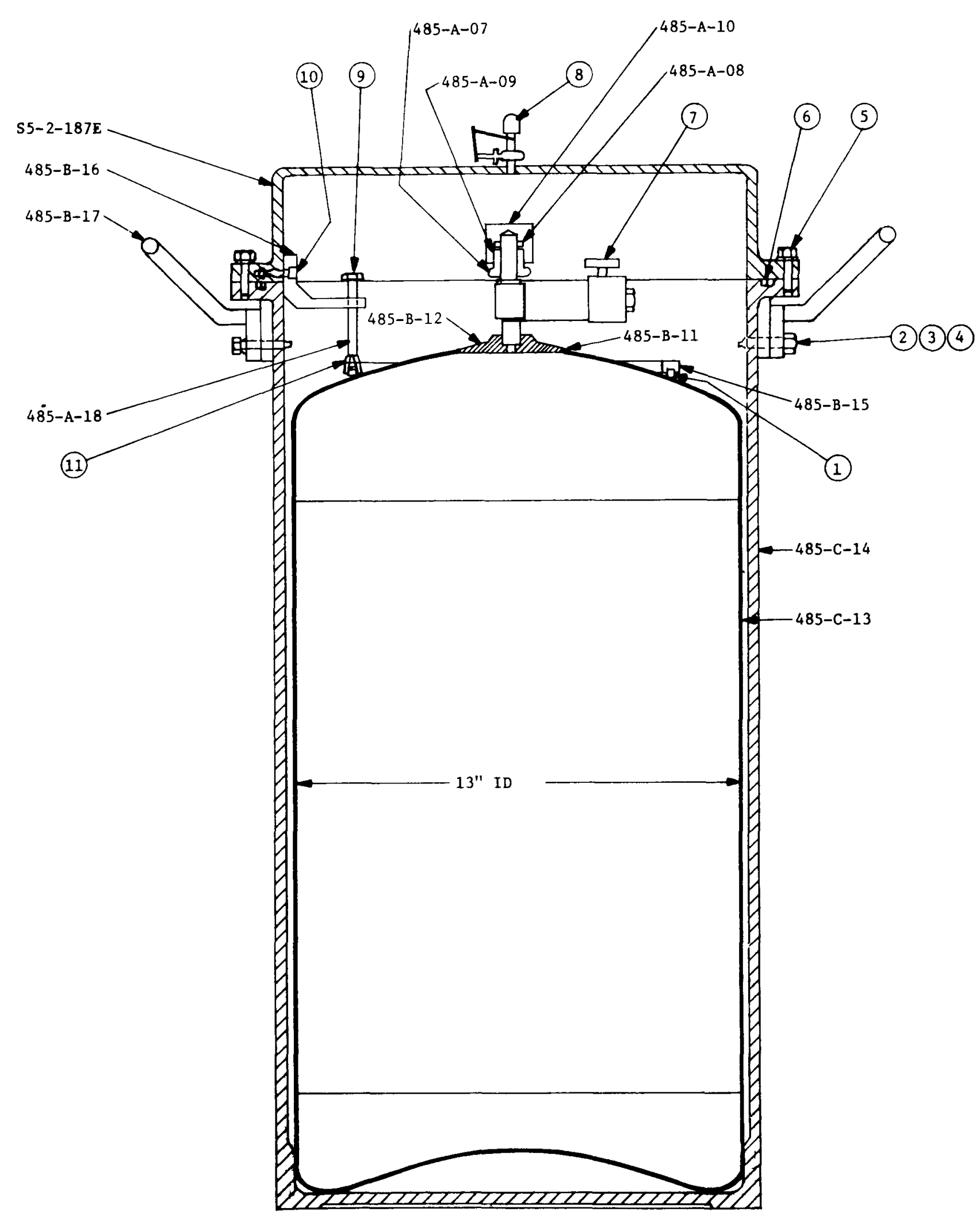

1. Inside surface of container must be free of grease, oxide, dirt and other foreign immerse in bath composed of $10-15 \%$ hydrofluoric acid (by volume) for 10-15 minutes at a temperature of $120^{\circ}-140^{\circ} \mathrm{F}$. Thoroughly rinse in water and dry.

2. Maximum leakage of container under vacuum shall be not more than 0.1 micron cubic foot per hour.

3. Container shall be annealed in cracked natural gas at $1800^{\circ}-2100^{\circ} \mathrm{F}$. A bright stainless steel pickling operation to follow firing.

4. Castings shall be smooth and free of air holes.

5. All welds to be made with 1/16-diameter type ER 308L SS rod using inert gas arc.

6. Flow helium through can while welding.

7. Parts S5-2-187B and S5-2-187E to be impregnated with "Mogul Cast Seal" in accordance with spec. AN-1-36 to ensure leak-tightness. The parts are to be tested by submersion in water with 20 -psig air pressure within the container.

\begin{tabular}{|c|c|c|c|c|c|}
\hline & & 11 & 3 & $1 / 4-28$ NF jam nut, zinc or cad plated & std \\
\hline & & 10 & 3 & $1 / 4-20 \mathrm{NC} \times 3 / 4$ soc hd capscr, zinc or cad plated & Std \\
\hline & & 9 & 3 & $1 / 4-28 \mathrm{NF} \times 2-1 / 2$ hex hd capscr, zinc or cad plated & Std \\
\hline & & 8 & $\frac{1}{1}$ & Hoke valve No. 450 comm & Std \\
\hline \multirow[t]{7}{*}{$54-2-147$} & & 7 & 1 & Vacuum tank valve & \\
\hline & & 6 & 1 & o-ring-linear No. $1820-84$ comm & Std \\
\hline & & 5 & 4 & $1 / 4-20 \mathrm{NC} \times 1$ hex hd capscr, zinc or cad plated & Std \\
\hline & & 4 & 8 & $1 / 4$ flat washer, zinc or cad plated & Std \\
\hline & & 3 & 8 & 1/4 lock washer, zinc or cad plated & Std \\
\hline & & $\frac{2}{2}$ & 4 & $1 / 4-20 \mathrm{NC} \times 1-1 / 8$ hex hd capscr, zinc or cad plated & Std \\
\hline & & 1 & 1 & 0-ring-linear No. $1820-74$ comm & Std \\
\hline $\mathrm{S} 5-2-187 \mathrm{E}$ & & & 1 & Container-bucket cover, made from $485-\mathrm{C}-02 \mathrm{R}$ & \\
\hline S5-2-186D & $485-A-18$ & & 3 & Spring, zinc or cad plated & \\
\hline S5-2-186C & $485-B-17$ & & $\overline{2}$ & Handle, made from $485-\mathrm{C}-06 \mathrm{R}$ & \\
\hline$S 5-2-186 \mathrm{~A}$ & $485-B-16$ & & 3 & Bracket, made from $485-\mathrm{B}-05 \mathrm{R}$ & \\
\hline S5-2-186B & $485-B-15$ & & 1 & Retaining ring, made from $485-\mathrm{B}-04 \mathrm{R}$ & \\
\hline S5-2-187B & $485-C-14$ & & 1 & Container bucket, made from $485-\mathrm{C}-03 \mathrm{R}$ & \\
\hline \multirow[t]{3}{*}{ S5-2-187A } & $485-C-13$ & & $\frac{1}{1}$ & Container assembly & \\
\hline & $485-B-12$ & & 1 & Fitting, see $485-C-13$ & \\
\hline & $485-B-11$ & & & Head top, see $485-\mathrm{C}-13$ & \\
\hline S5-2-187C & $485-\mathrm{A}-10$ & & 1 & Plug receptor & \\
\hline $55-2-187 \mathrm{~F}$ & $485-\mathrm{A}-09$ & & 1 & Gasket washer & \\
\hline S5-2-187D & $485-A-08$ & & 1 & Compression gasket & \\
\hline $\mathrm{S} 5-2-186 \mathrm{E}$ & 485-A-07 & & 1 & Compressor plug & \\
\hline PART NO. & DRAWING No. & & $\begin{array}{lll}\text { No. } \\
\text { NEOD }\end{array}$ & & \\
\hline
\end{tabular}



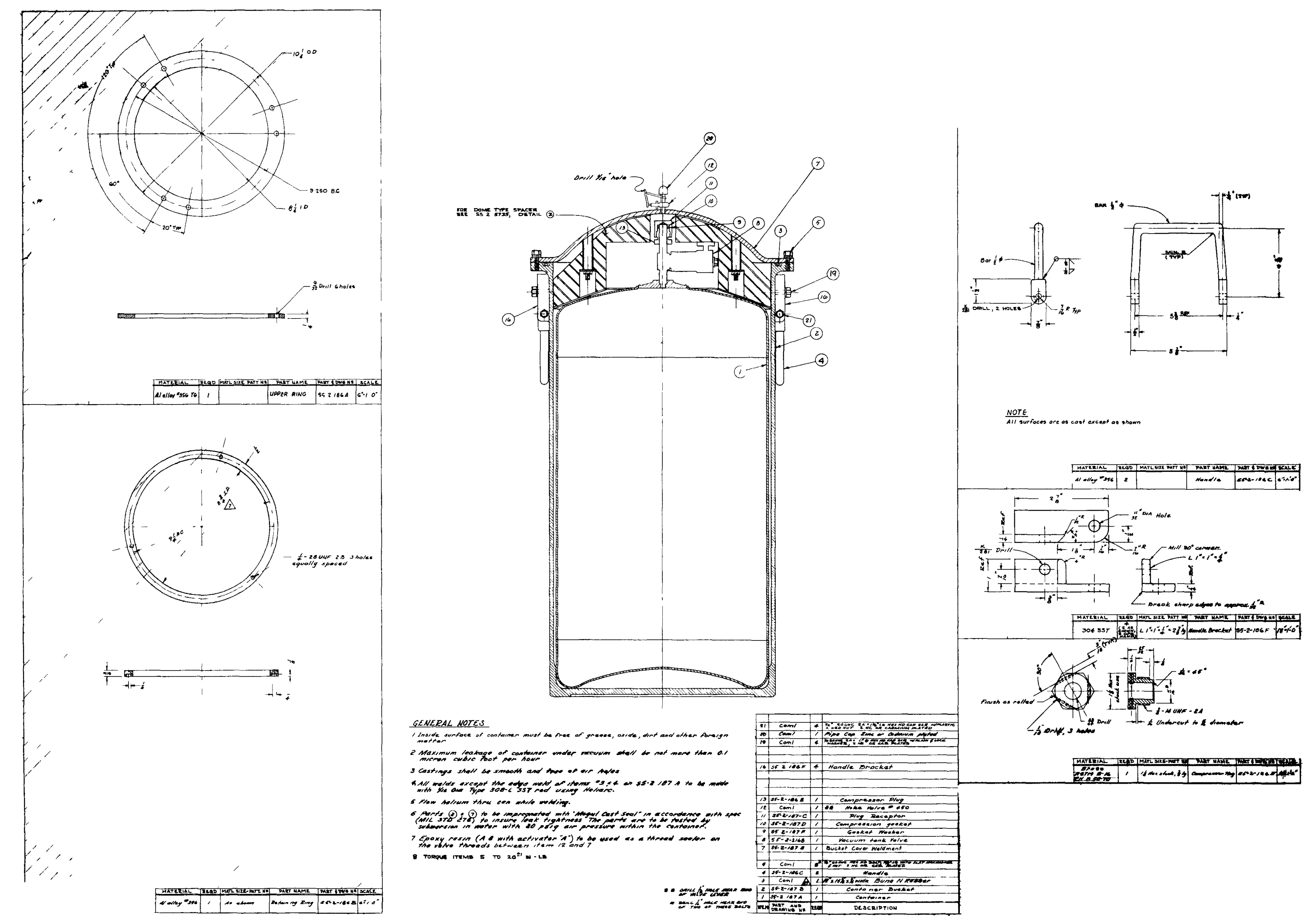


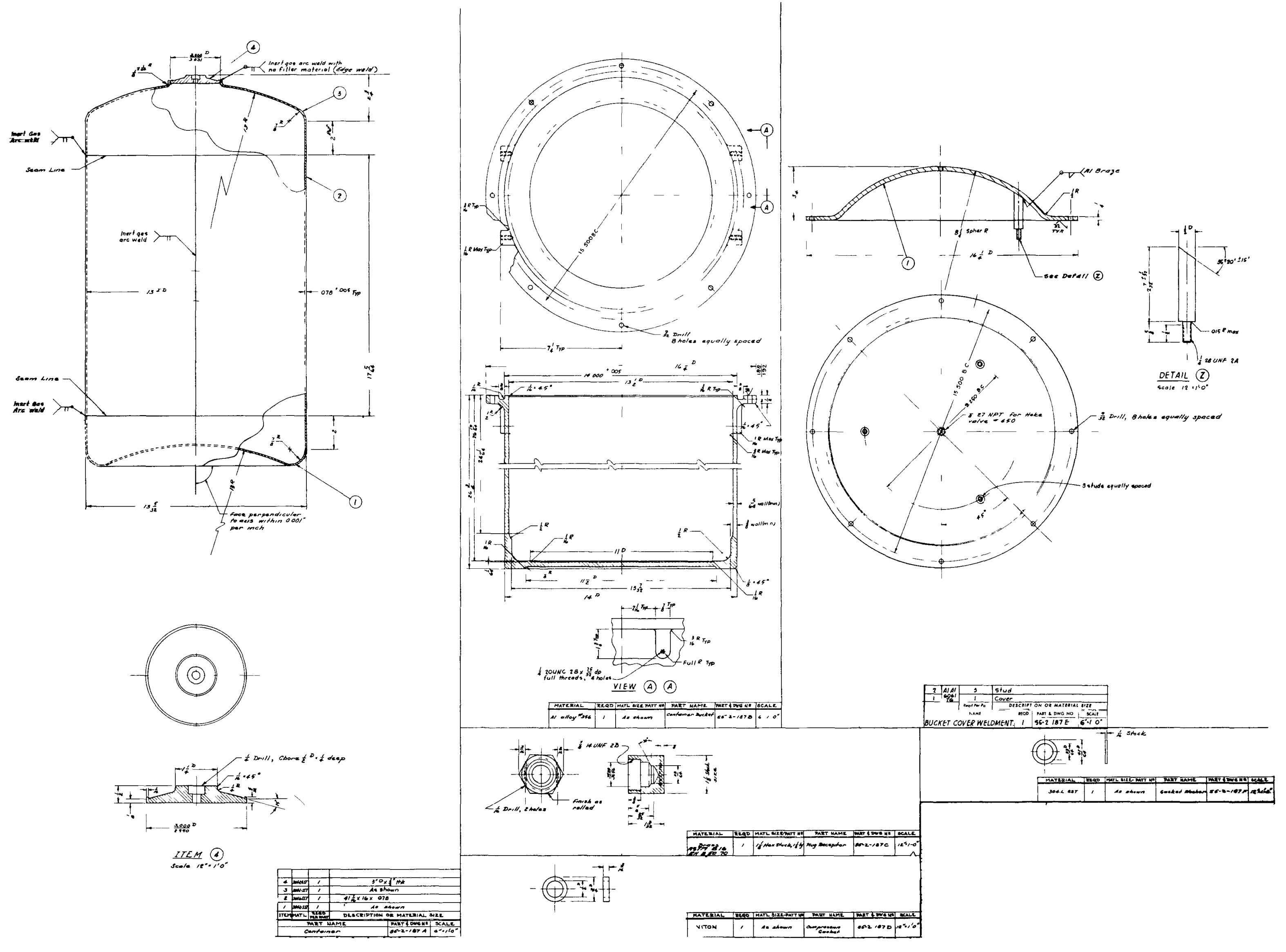

Figure 6. LP.50 tRANSFer CONTAINER - DetalLS (Du Pont dwg 55-2.187, Rev 22, November 1974) 


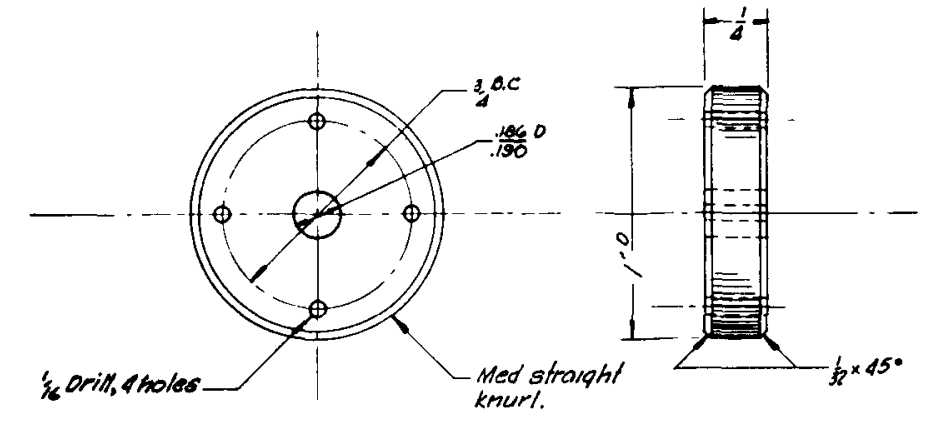

(4) AO JUSTING KNOB
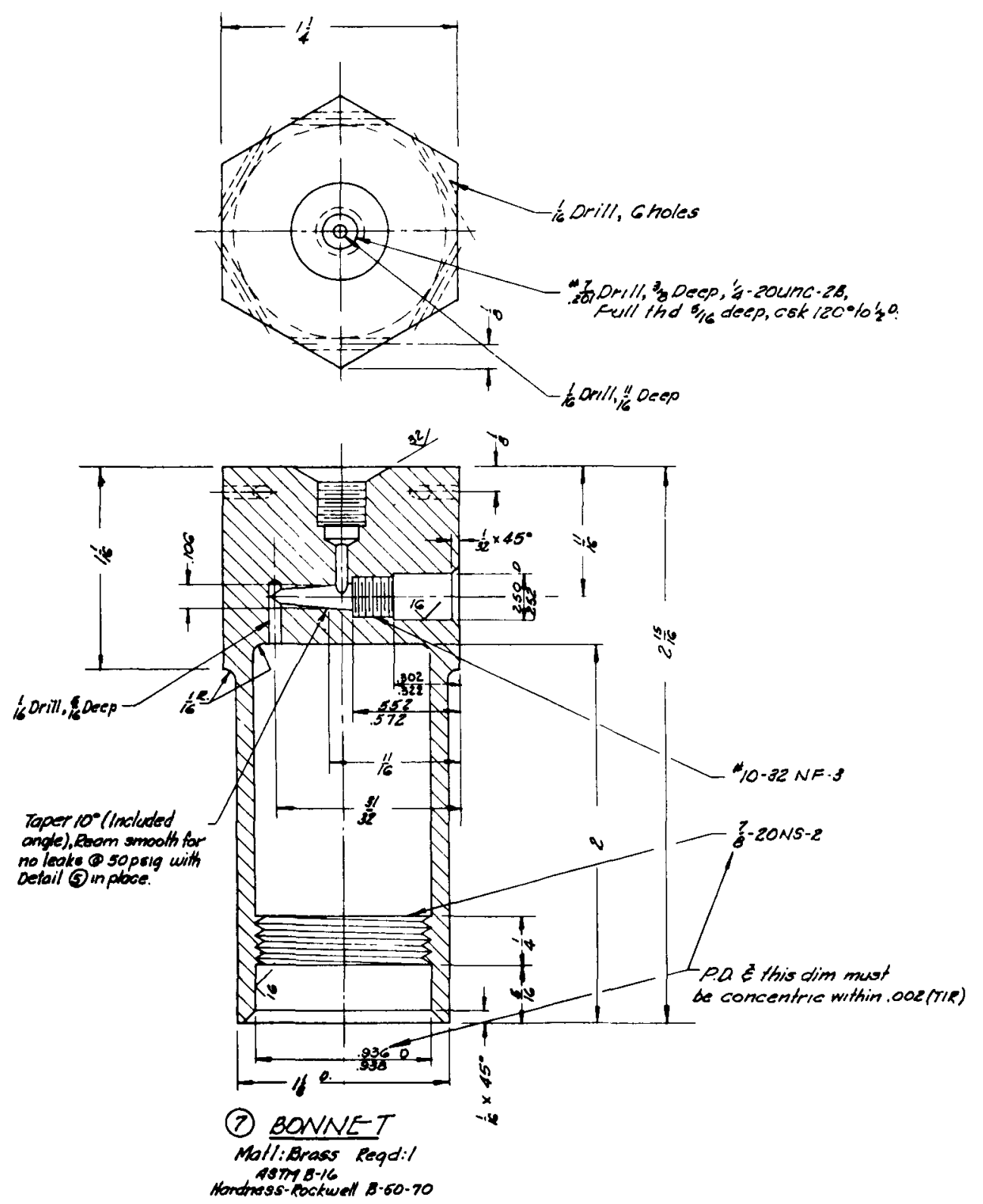

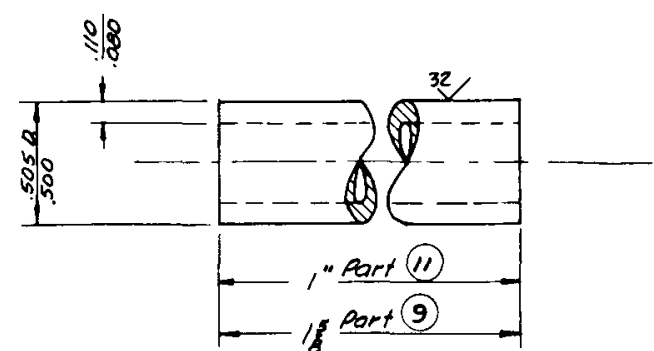

(9)(11) TUBE

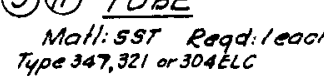
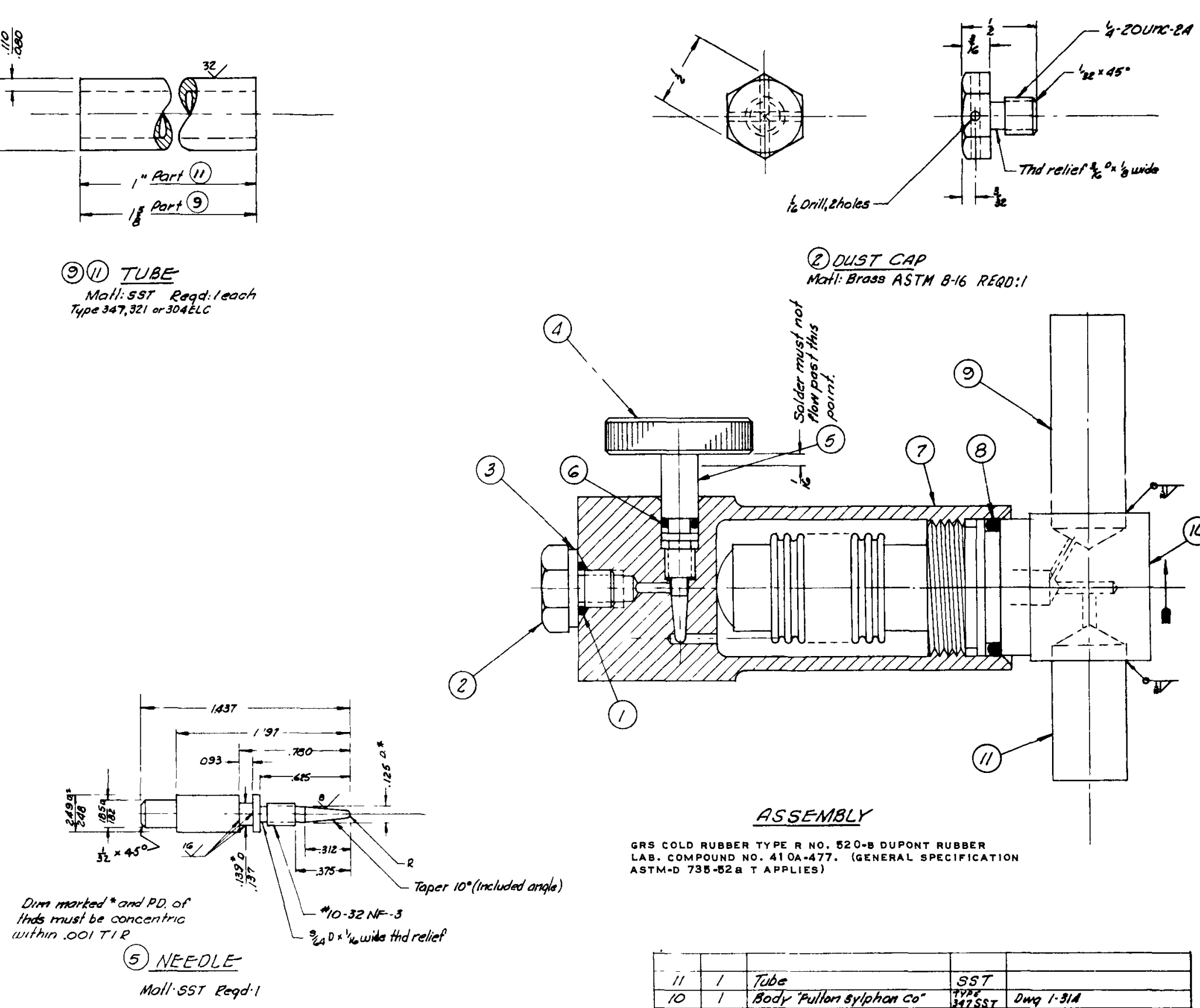

Matl: Bross ASTM B-16 REQO:!

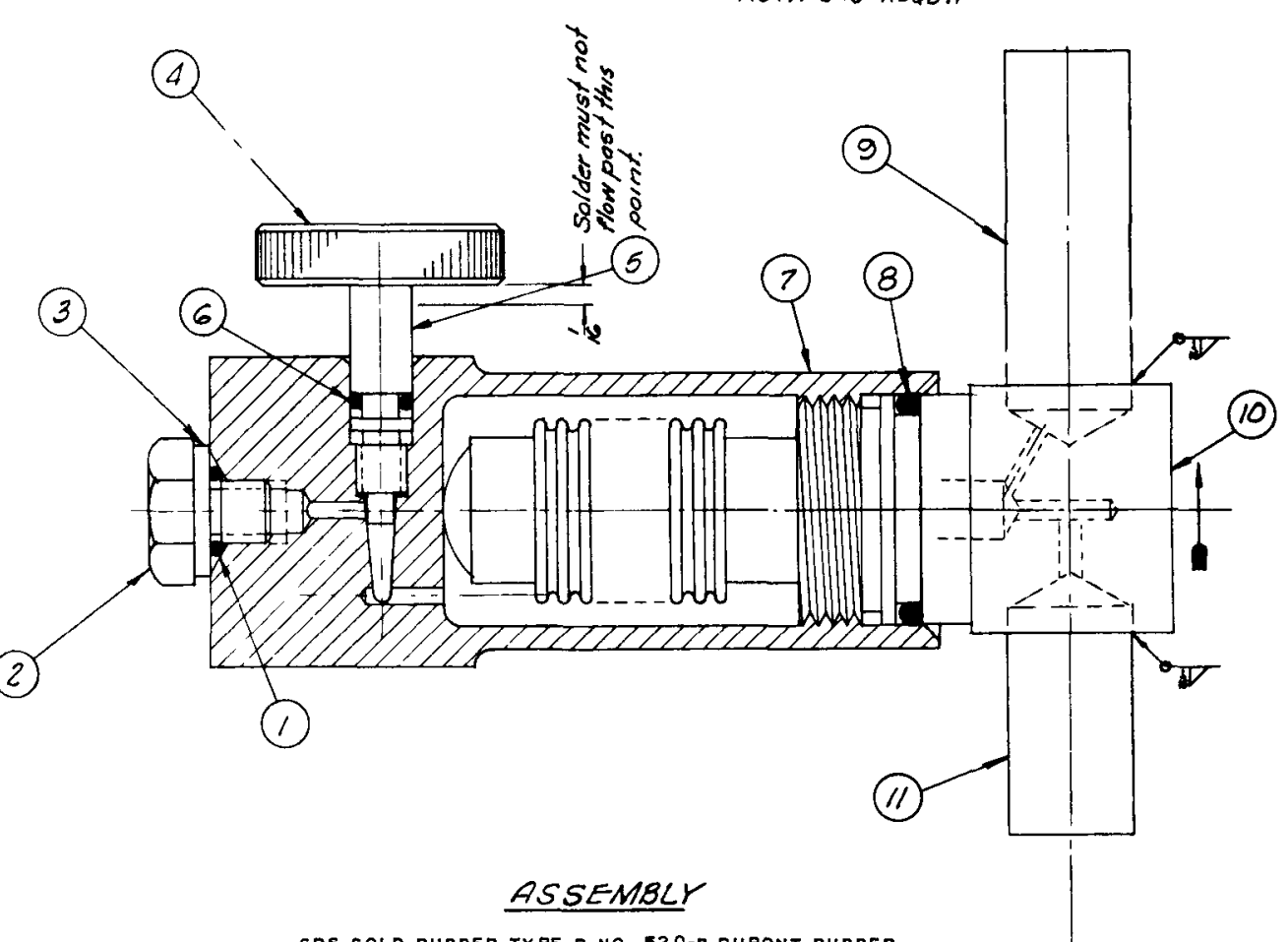

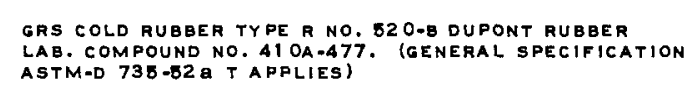

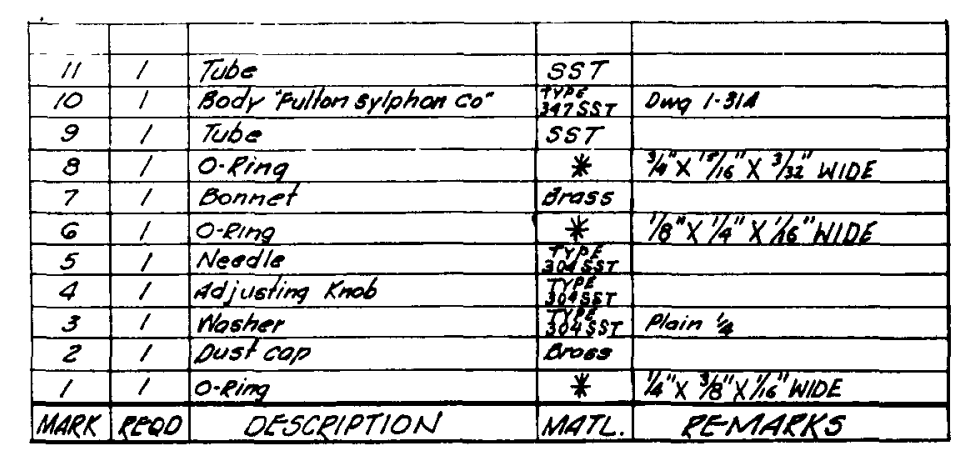

Figure 7. PRODUCt CONTAINER VACUUM TANK VALVE - MARK II (Du Pont dwg \$5.2-147, Rev 13, November 1974) 


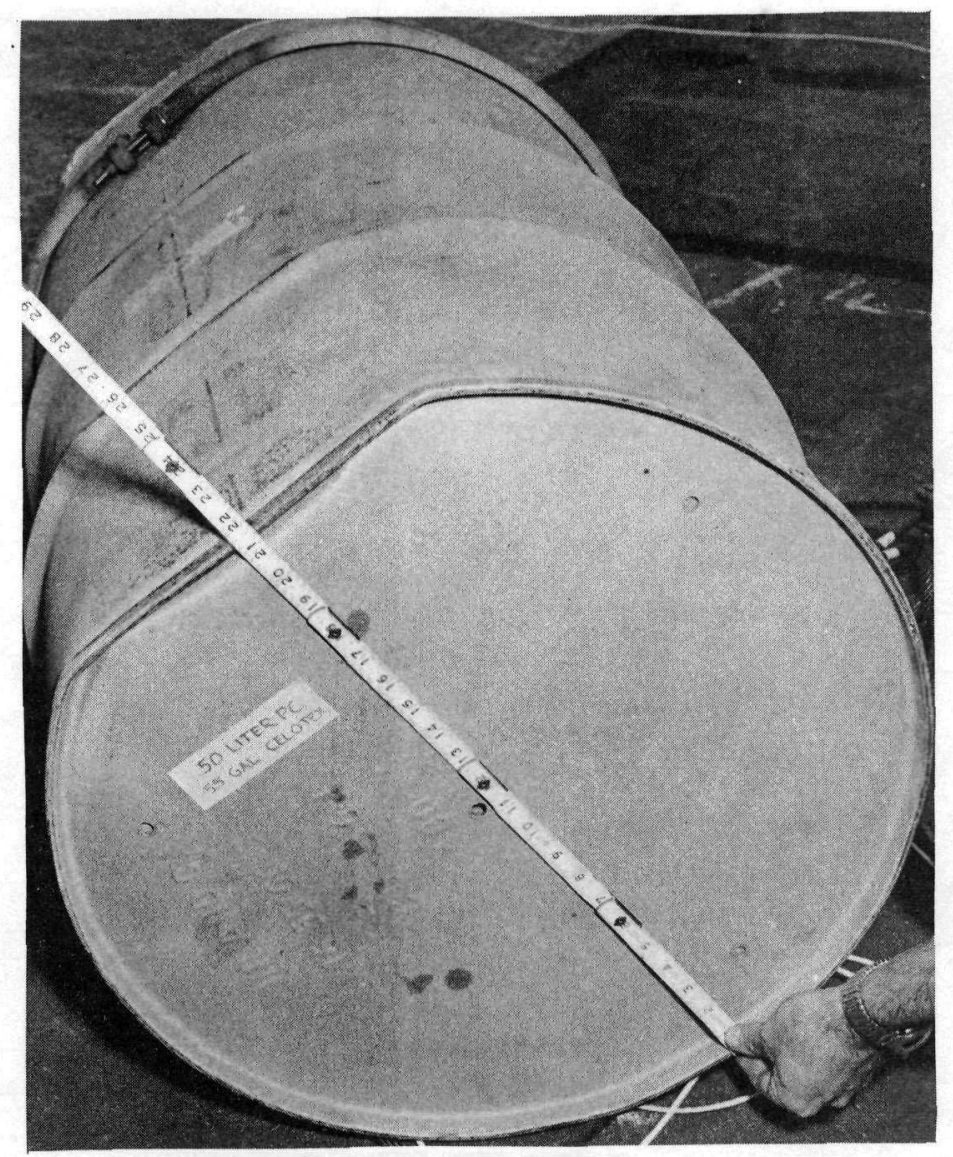

FIGURE 8. FIRST FIRE TEST - EFFECT OF 30-FOOT DROP ON SIDE

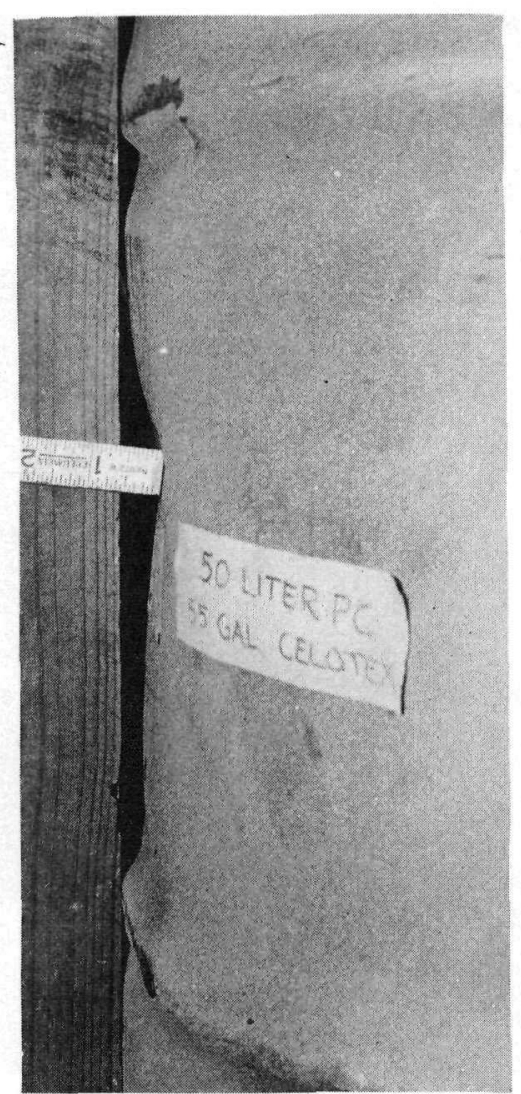

FIGURE 9. FIRST FIRE TEST - EFFECT OF 40-INCH DROP ON 6-INCH PISTON

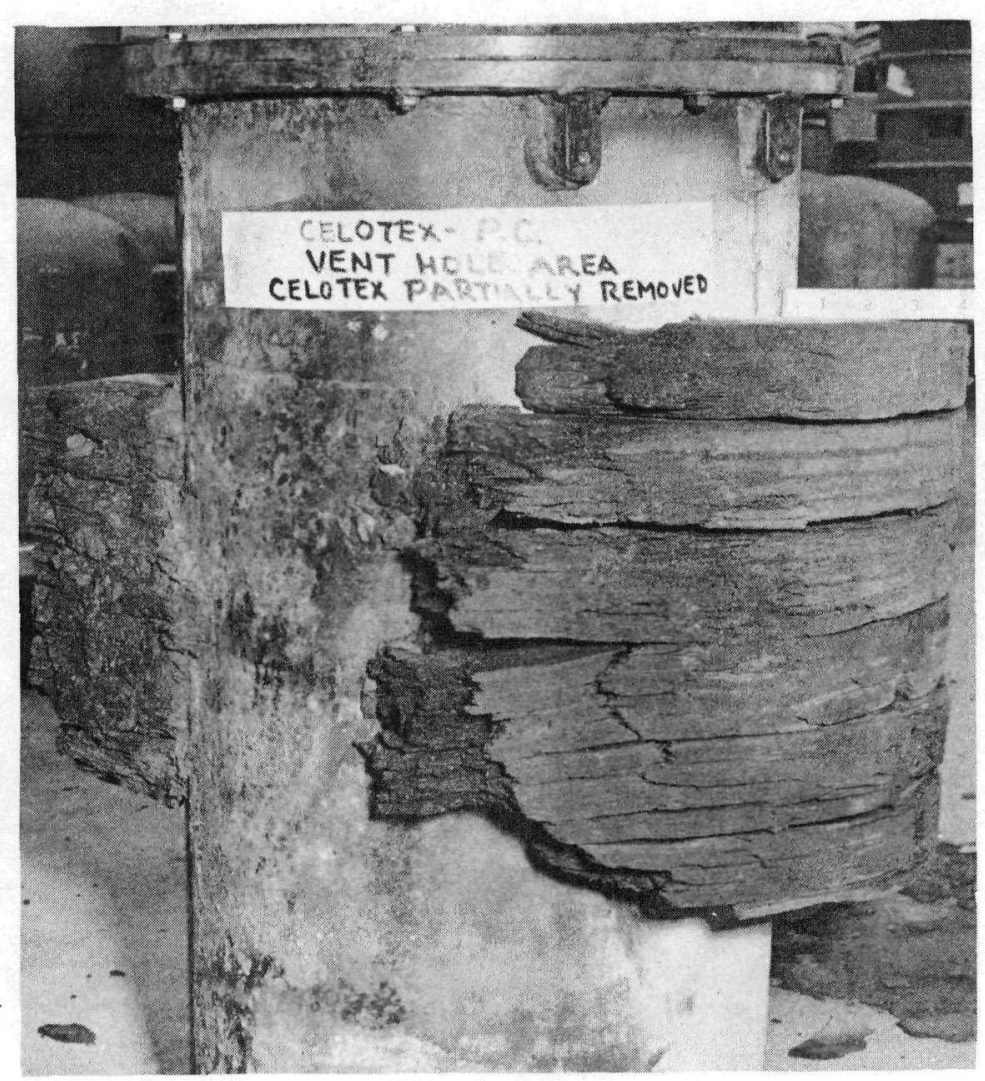

FIGURE 10. FIRST FIRE TEST - EFFECT OF SMOLDERING IN AREA OF VENT HOLES 


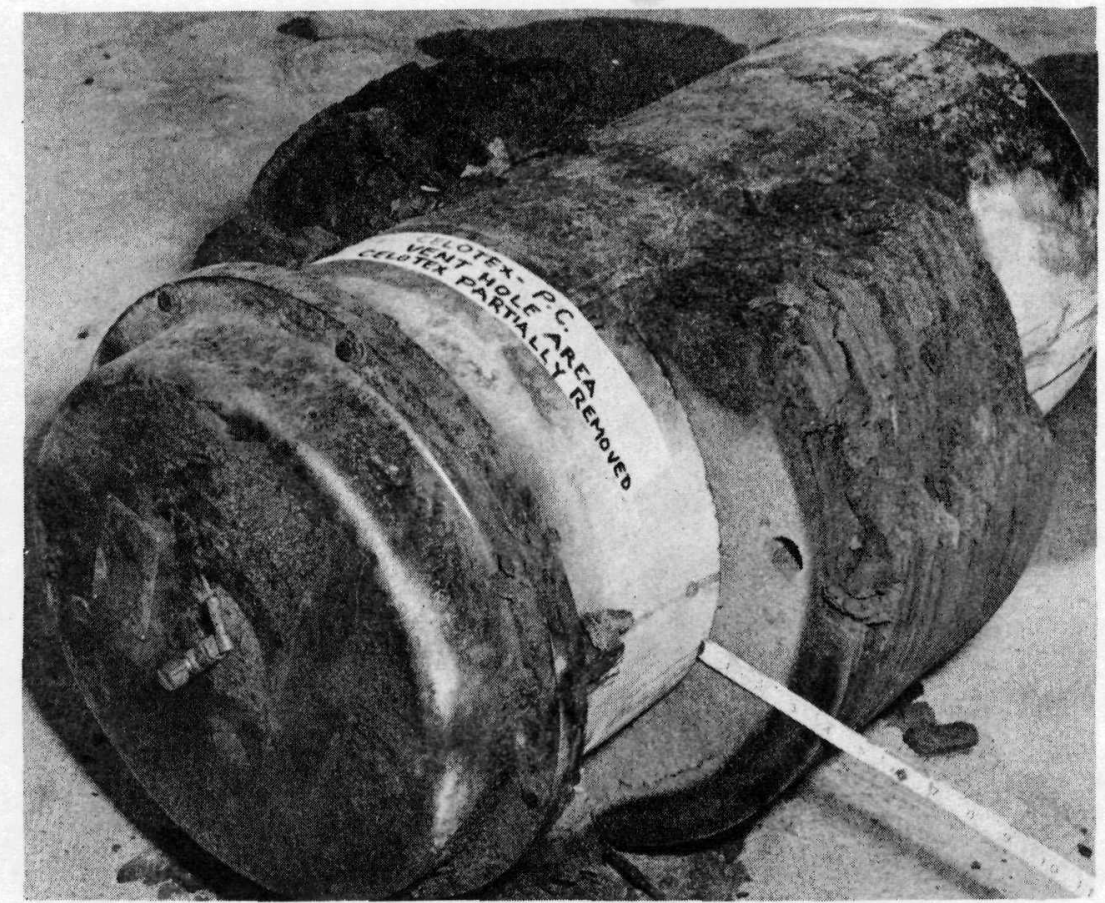

FIGURE 11. FIRST FIRE TEST - UNBURNED "CELOTEX" AWAY FROM VENTS

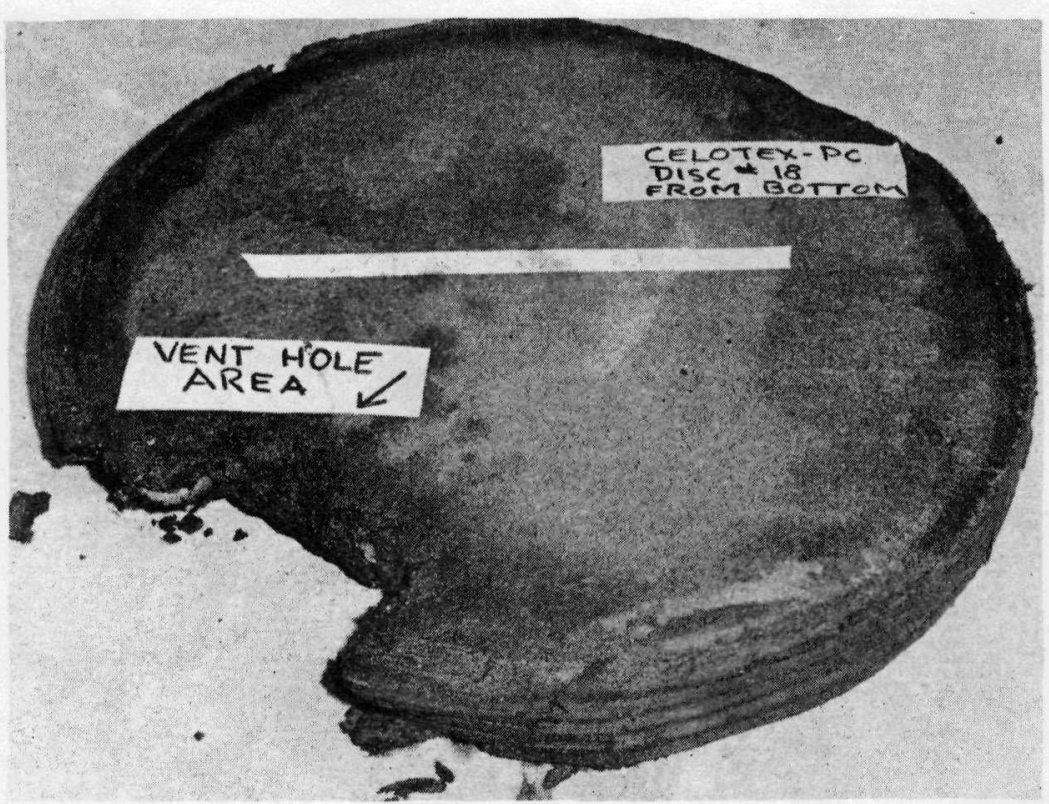

FIGURE 12. FIRST FIRE TEST - EFFECT OF SMOLDERING ON BOTTOM "CELOTEX" DISK NEAR VENT

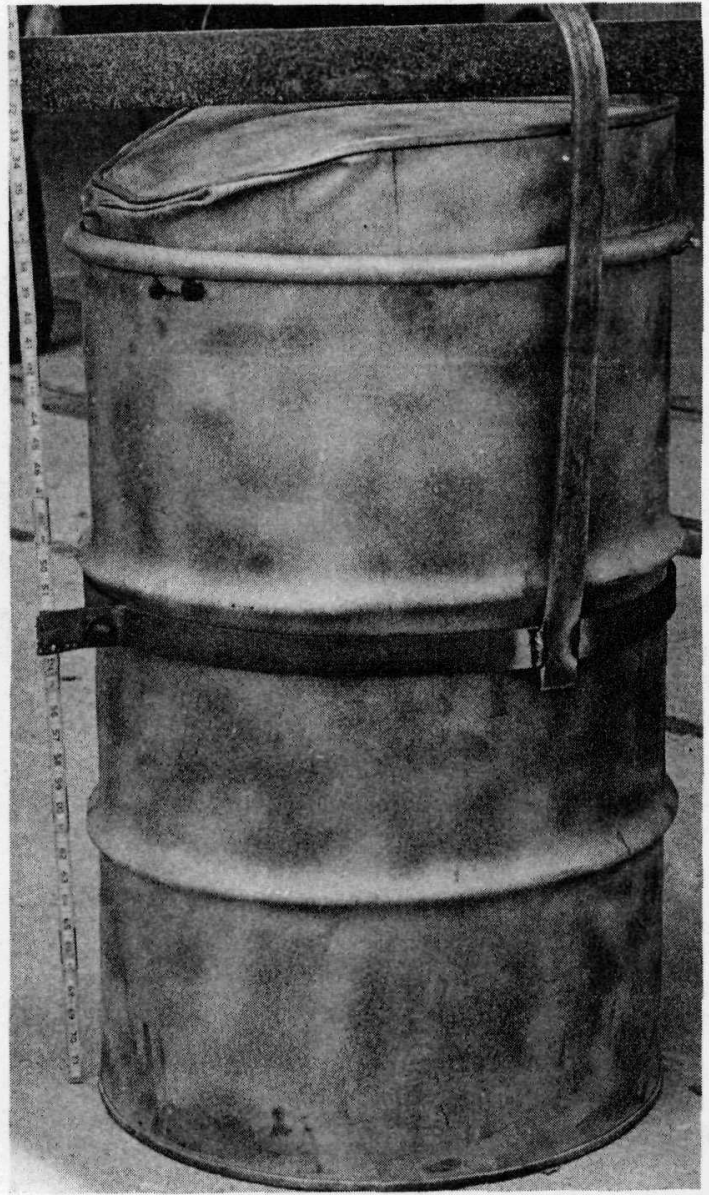

FIGURE 13. SECOND FIRE TEST - EFFECT OF 30-FOOT DROP ON END OF DRUM AND OF PISTON DROP 


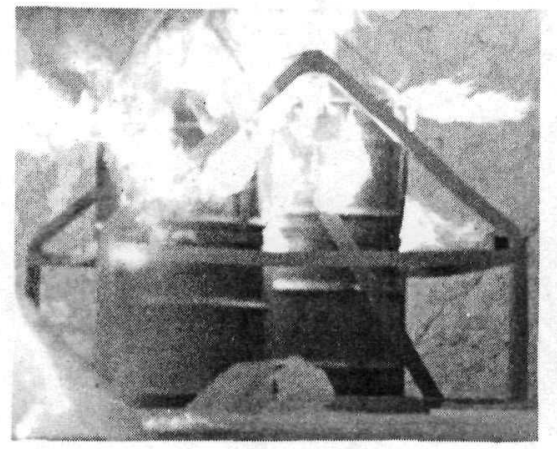

FIGURE 14. SECOND FIRE TEST - VIEW IN FURNACE DURING TEST

(Tritium Container on Left)

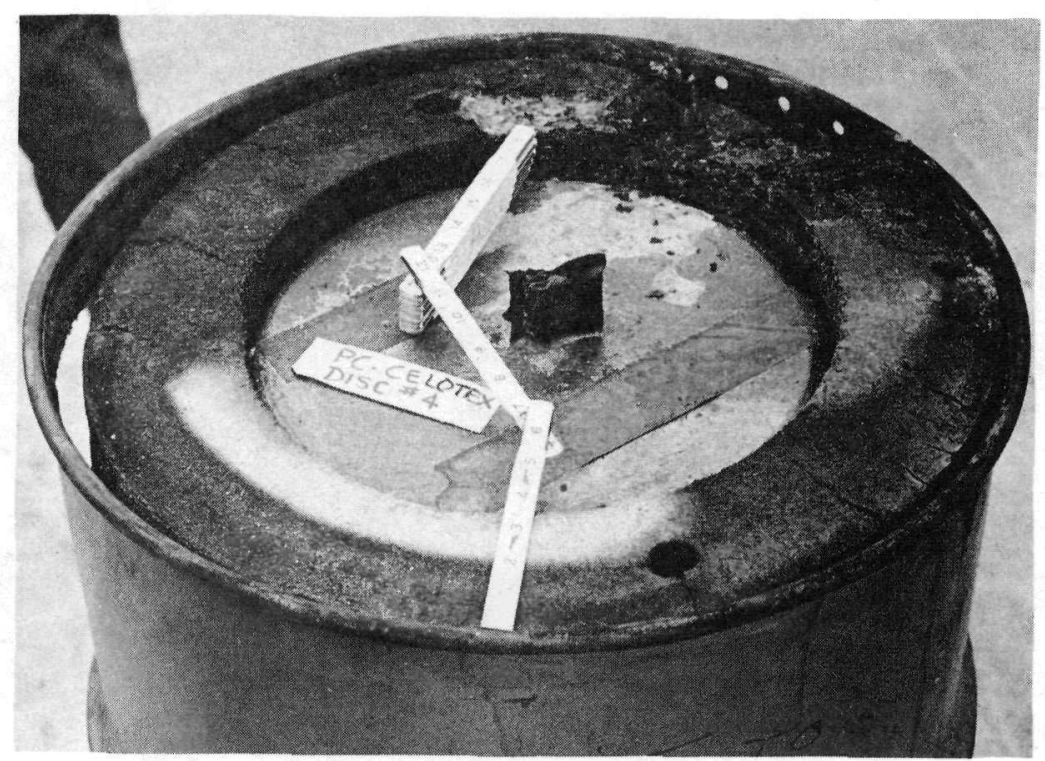

FIGURE 15. SECOND FIRE TEST - EFFECT OF SMOLDERING NEAR VENTS

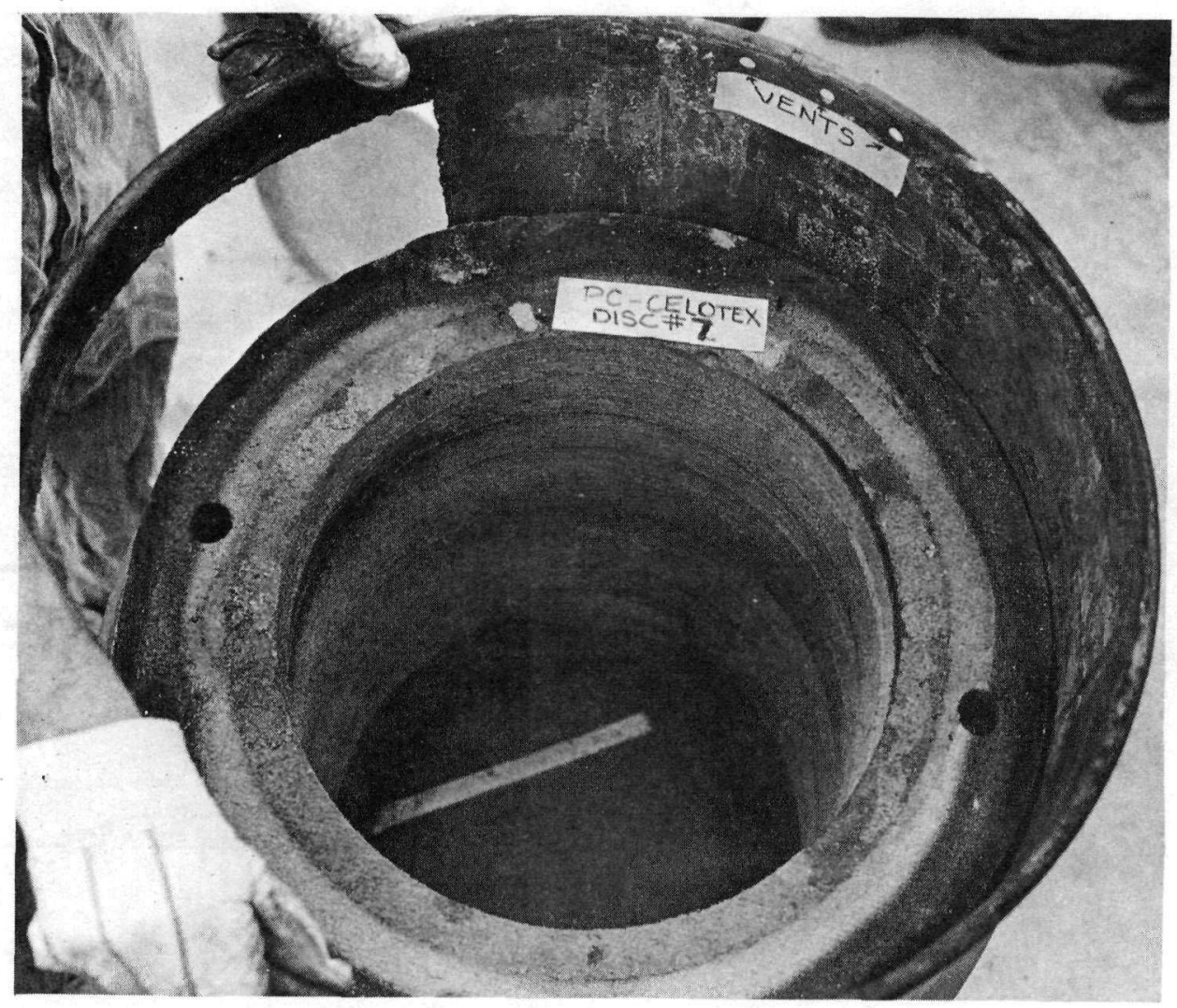

FIGURE 16. SECOND FIRE TEST - SHOWING GOOD CONDITIONS OF "CELOTEX" BELOW VENTS 


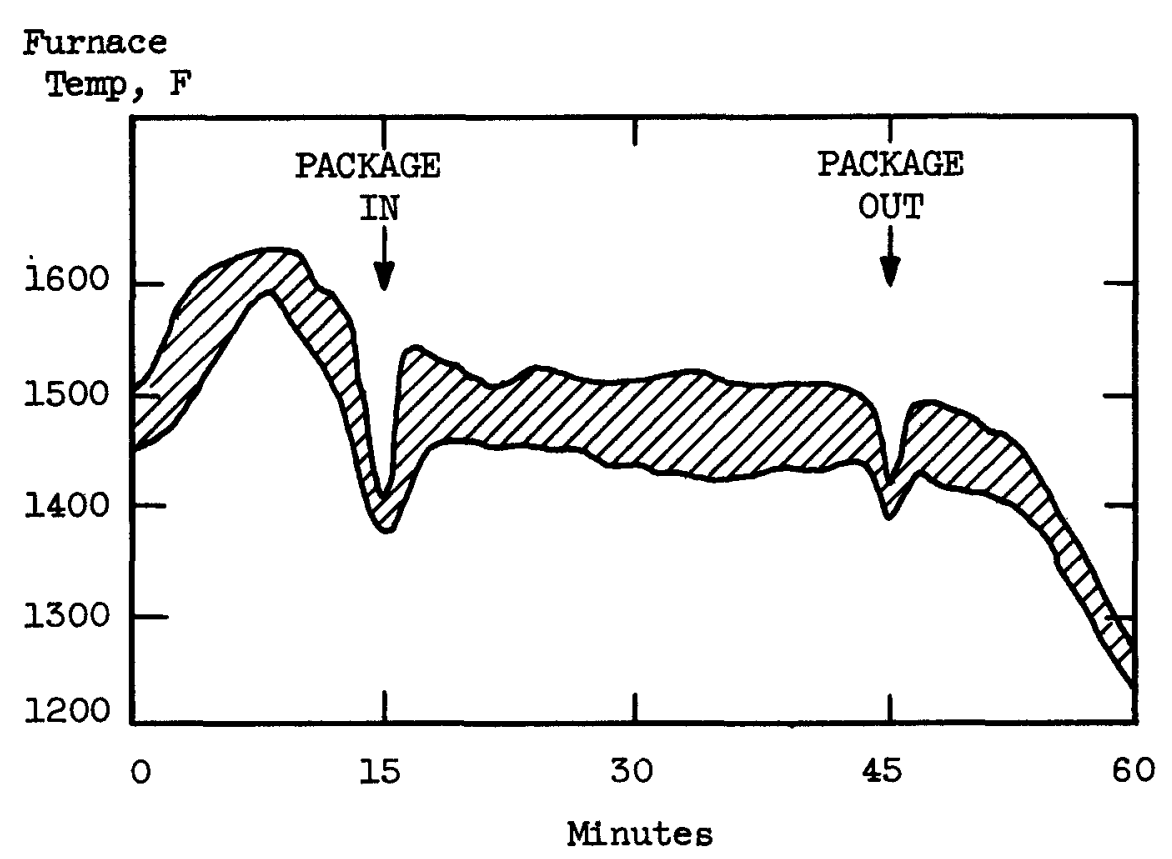

FIGURE 17. FIRE TEST TEMPERATURE

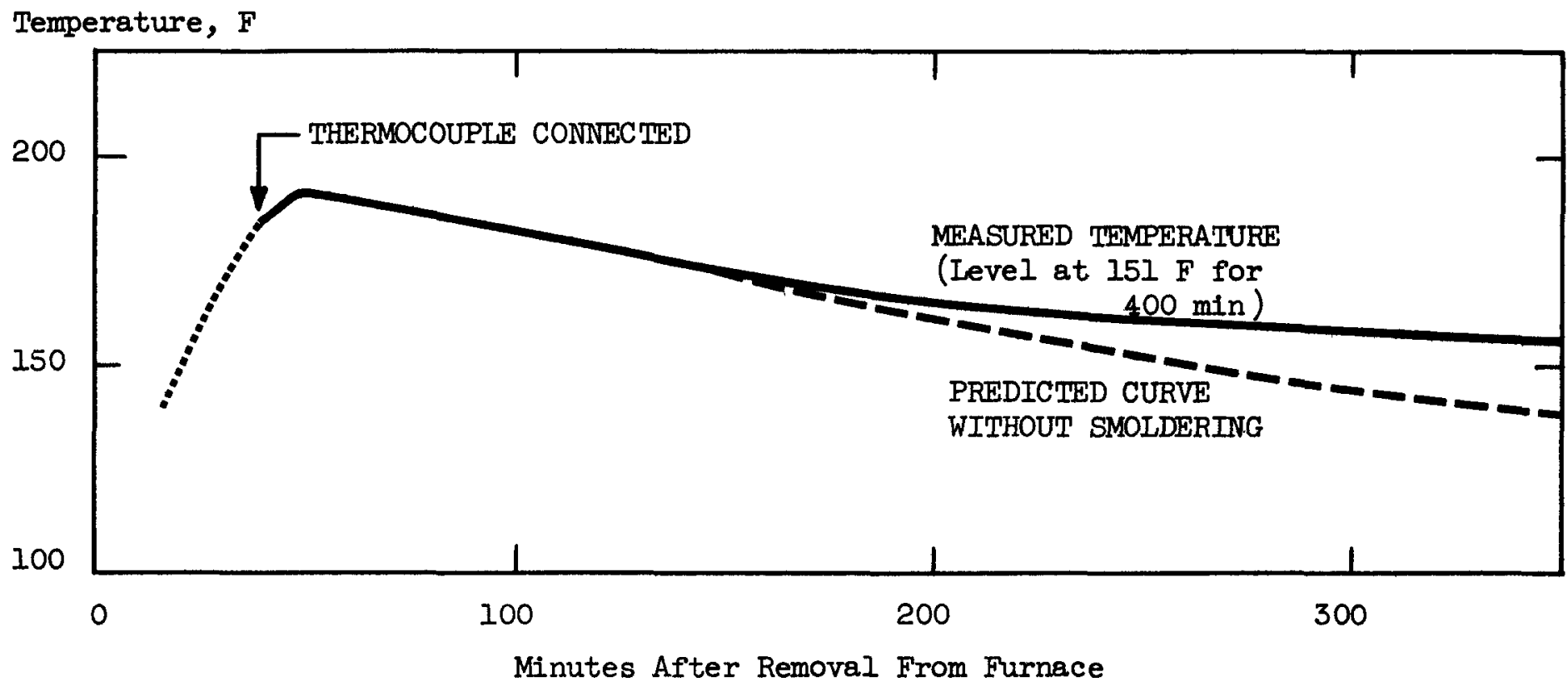

FIGURE 18. ALUMINUM VESSEL TEST TEMPERATURE 


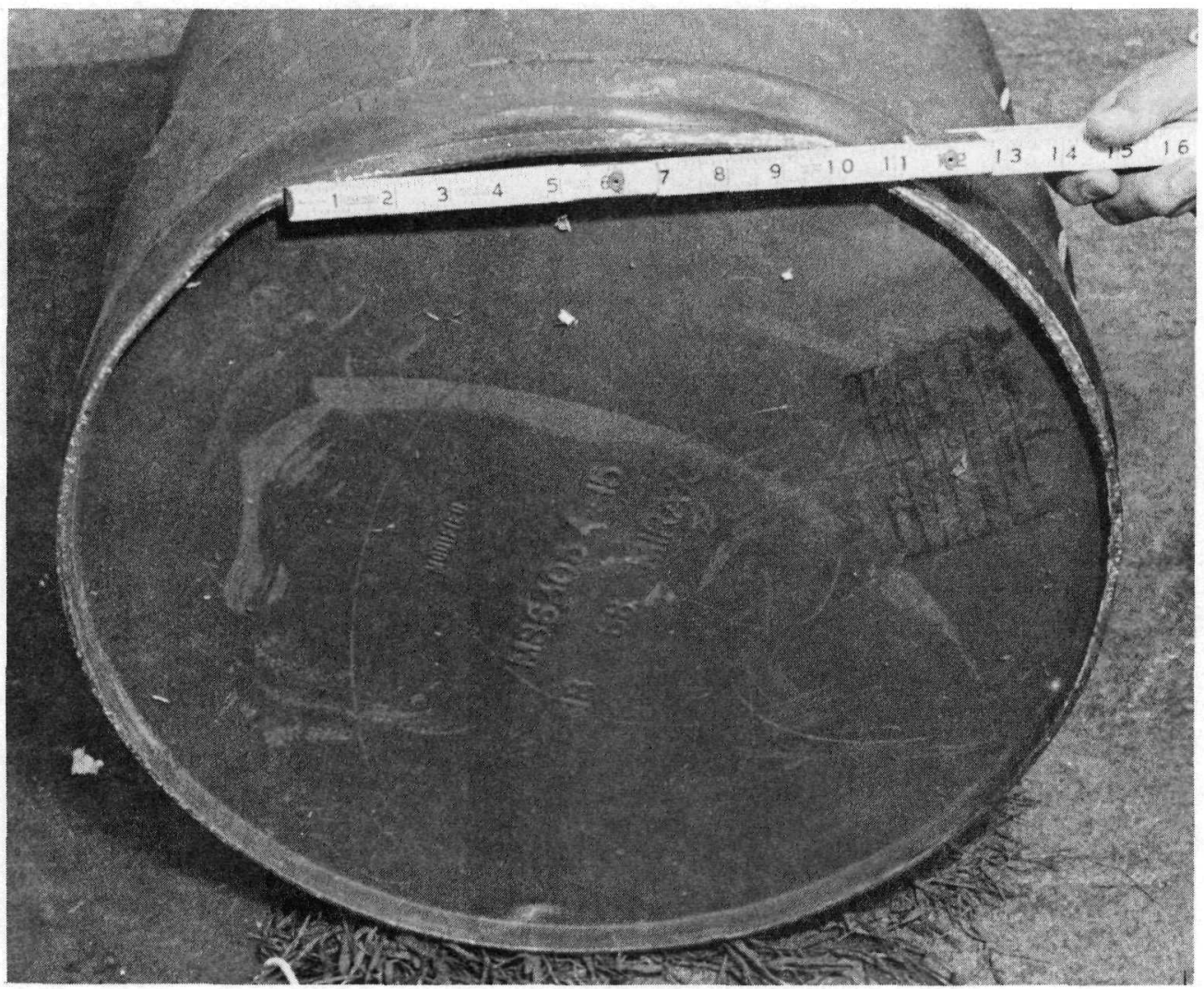

FIGURE 19. FOUR-FOOT DROP ON BOTTOM EDGE
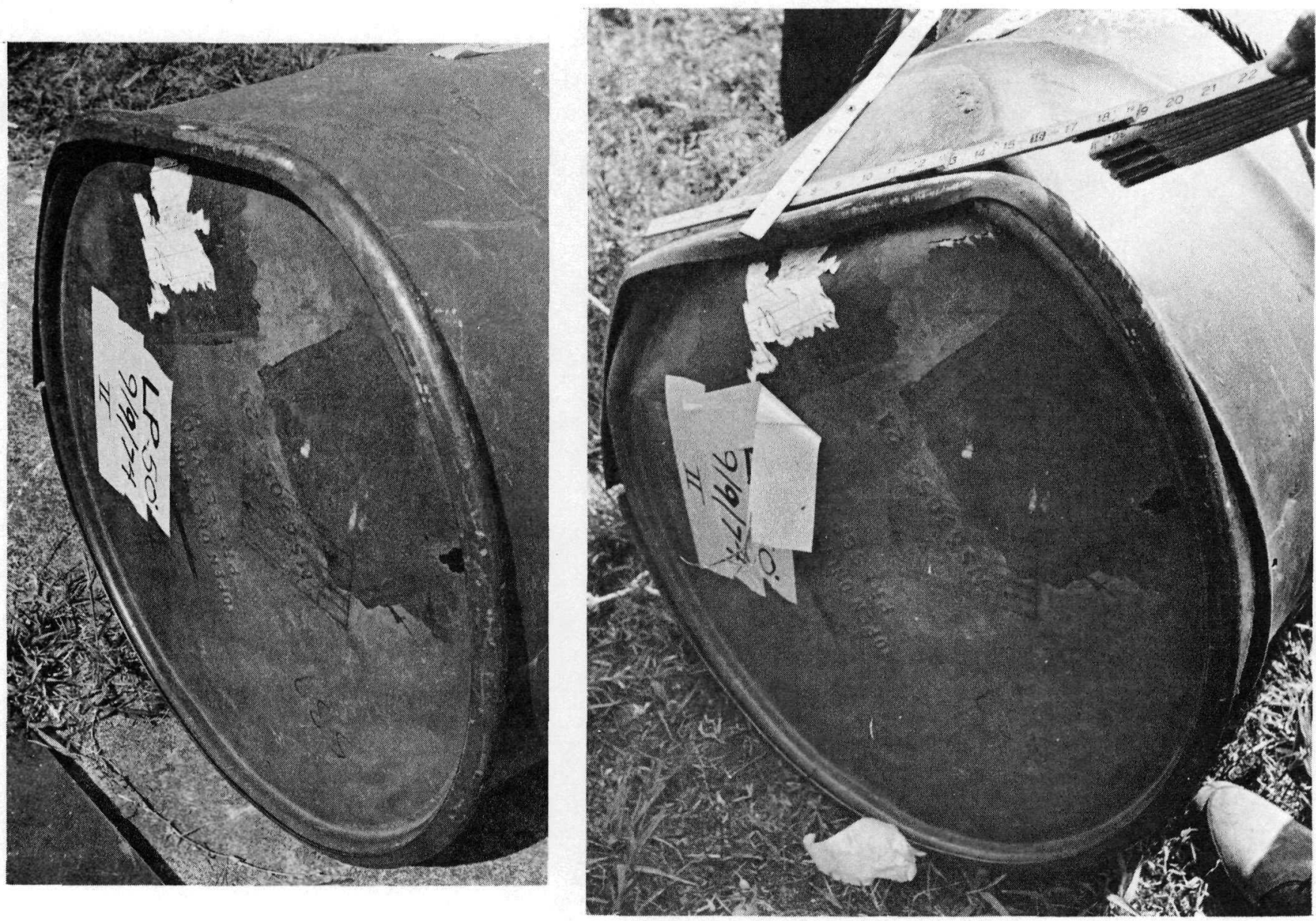

FIGURE 20. FOUR-FOOT DROP ON TOP EDGE 


\section{Chapter 0529 SAFETY STANDARDS FOR THE PACKAGING OF FISSILE AND OTHER RADIOACTIVE MATERIALS}

\section{9-01 POLICY}

Fissile and other radioactive material shall be packaged and prepared for shipment in a manner that provides assurance of protection of the public health and safety during the transportation of such materials.

\section{9-02 OBJECTIVE}

To establish safety standards for the packaging of fissile and other radioactive materials for shipment by AEC or by contractors not subject to 10 CFR 71 .

\section{9-03 RESPONSIBILITIES AND AUTHORITIES} Safety:

031 The Director, Division of Operational

a. determines the need for, and develops new and revised safeıy standards to be applied in the preparation of fissile and other radioactive materials for transportation.

b. provides a central point of coordination with the Director of Regulation for developing and revising health and safety codes pertaining to safety in the transportation of fissile and other radioactive materials which are intended for use in the AEC programs or by other federal agencies.

c. conducts periodic appraisals to determine the adequacy of the implementation of this chapter.

d. renders interpretations of this chapter.

032 The Director, Division of Waste Management and Transportation, in addition to the responsibilities and authorities assigned in 033 , below:

a. administers the program for design review and issuance of AFC Certificates of Compliance as provided in 056 , below, ALCM 5201, and 4) CFR 172.39173 .396$.

b. assists field offices in expediting essential shipments consigned to or by AEC and in securing waivers or exemptions from Federal Transportation Regulations.

c. prepares guidance criteria and procedures for application of package testing and quality assurance standards.

d. coordinates the total input for the General
Manager in the development and revision of transportation regulations.

033 Heads of Divisions and Offices, Headquarters, excluding Regulatory, provide guidance, instructions, standards, and criteria as described in Chapter 0101, consistent with this chapter, to assure the safe packaging of fissile and other radioactive materials, including:

a. directing cognizant managers of field offices to require modifications of equipment procedures or practices.

b. imposing additional requirements for packaging standards.

c. curtailing or suspending the use of specific packages when necessary.

034 Managers of Field Offices, and the Director, Division of Naval Reactors, consistent with guidance, instructions, standards, and criteria issued pursuant to 033, above:

a. grant AEC approval for packages which meet the standards contained in appendix 0529 and 10CFR 71.31--71.40, and which are to be used for the transportation of fissile or other radioactive materials in greater than Type A quantities.

b. grant AEC approval for shipments made under the National Security Exemption provided to the AEC and DOD under the Transportation of Explosives Act (18 U.S.C. $832 \mathrm{c})$ and in accordance with the requirements of pertinent AEC manual chapters. Packages for such shipments must meet the policy stated in section 01 .

c. grant such alternatives to the requirements set forth in appendix 0529 as will provide equivalent protection to life or property and to the common defense and security; and within $\mathbf{3 0}$ days after granting an alternative. provide the Director. Division of Operational Safety, a detailed report of the reasons for granting it. The granting of such alternatives is in no way to be construed as the granting of exemptions or exceptions from or to the Department of Transportation or other regulatory agency requirements.

d. conduct annual appraisais of contractor operations to assure compliance with the 
requirements of this chapter.

e. require that their contractors carry out, as a minimum, quality assurance programs described in this chapter, and as provided for in appendix 5201.

(NOTE: Contractors shall not be permitted to exercise any of the above authorities.)

035 The Manager, Albuquerque Operations Office, in addition to the responsibilities and authorities assigned in 032 , above, shall establish safety standards for packaging and transportation of nuclear weapons and their components in accordance with 055 , below.

\section{9-04 DEFINITION}

041 AEC Contractor for the purposes of this chapter, means a prime contractor or subcontractor of the Atomic Energy Commission who is exempt from the requirements of 10 CFR 71 .

\section{9-05 BASIC REQUIREMENTS}

051 Applicability. The provisions set forth in this chapter and its appendix apply to the Headquarters, field offices, and AEC contractors.

052 Coverage. This chapter and its appendix cover policies and procedures for the preparation of fissile and other radioactive materials for shipment outside the boundaries of AEC-controlled sites by for-hire or private carriers, or on public vehicles or aircraft.

053 Federal Regulations. When offered to the carrier, each shipment of radioactive materials shall be in compliance with the applicable safety regulations of the Department of Transportation (DOT) or the U.S. Postal Service, depending on the mode of transportation.

\section{Other Regulations}

a. International Atomic Energy Agency (IAEA) Regulations. Each shipment of fissile and other radioactive materials consigned to a foreign country must meet the requirements set forth in IAEA Safety Series No. 6, "Regulations for the Safe Transport of Radioactive Materials." Specifically, "Requirements for Packaging and for Delivery of Packages to Transport," must be met to be in compliance with this chapter.

b. International Air Transport Association (IATA) Restricted Article Regulations. Each shipment of fissile and other radioactive materials consigned to a foreign country must meet the requirements set forth in IATA Restricted Articles Regulations when shipped via commercial aircraft.

c. U.S. Air Force AFM-71-4, Packaging and Handling of Dangerous Materials for Transport by Military Aircraft. Each shipment of fissile and other radioactive materials must meet the requirements set forth in AFM-71-4 when shipped via USAF aircraft.

055 Package Standards for Radioactive Materials in Amounts Greater Than Type A Quantities

a. Packages of radioactive materials shall be prepared for shipment and transported in accordance with the provisions of this chapter. DOT specification containers for Type $B$ and fissile materials are considered to meet the standards of this chapter, and no specific AEC Certificates of Compliance are required for their use.

b. Nuclsar weapons and their components shall be packaged and transported in accordance with the standards in this chapter or with other standards which provide a degree of safety at least equivalent to that provided by the AEC and DOT regulations. Standards will be developed and documented under 035 , above.

c. Packages shipped under the National Security Exemption of 18 U.S.C. 832.c must be in compliance with the standards in this chapter and must also comply with the provisions of other pertinent AEC manual chapters.

d. All other packages for fissile and other radioactive materials in amoun ts greater than Type A quantities shall be designed, constructed, and used in accordance with the standards contained in the attached appendix, and in $10 \mathrm{CFR} 71.31-71.40$. Materials described in 71.6 are exempt from this requirement.

e. A quality assurance program must be established and implemented to assure that packages for radioactive materials are fabricated, maintained, and used in accordance with the regulations and approved design features. The program must meet the requirements in appendix 5201 .

056 AEC Certificates of Compliance for Packages of Radioactive Materials in Excess of Type A 
Quantities. Upon determination that a package design does in fact meet the requirements of this chapter and and its appendix and the AEC Standards in 10 CFR 71.31-71.40, an AEC Certificate of Compliance will be issued by the AEC to the contractor. Procedures for obtaining and issuing these certificates are set forth in AECM 5201. No certificate is necessary for shipments meeting the requirements of 10 CFR 71.6 or 71.7 .

057 AEC as Consignor. Where an AEC office serves as the actual consignor, rather than a contractor, appropriate internal procedures shall be established by the responsible field office manager to assure compliance with the standards contained in this chapter.

058 Waivers and Exemptions. Packages which do not meet the standards in the DOT Hazardous Materials Regulations, and which do not qualify for shipment under the National Security Exemption, may be shipped only under the provisions of a waiver or exemption issued by the DOT, or on public vehicles or aircraft if approved under the provisions of AEC 0529-034c. Applications for a DOT Special Permit for waiver or exemption shall be prepared in accordance with 49 CFR 170.13 and shall be forwarded to the DOT for issuance of a special permit.

059 Existing Packagings. Existing packagings for radioactive materials must meet the standards of this chapter. However, Type B packagings designed and constructed prior to February 15, 1969, which could be subject to loss of shielding resulting from subjecting the packaging to the puncture test followed by the thermal test (49 CFR $173.398(\mathrm{c})(2))$, are also approved for continued use. The packaging design must be covered by a DOT Special Permit providing for administrative and operational contro!s as may be necessary to compensate for the deficiencies in package integrity and to provide equivalent safety in transportation.

\section{9-06 REFERENCES}

a. AEC Regulation. Title 10, Code of Federal Regulations, Part 71, "Packaging of Radioactive Material for Transport."

b. DOT Regulations

1. Title 49, CFR Parts 170-189, and Title
14, CFR Part 103, "Hazardous Materials Regulations."

2. Title 46, CFR Part 146, "Transportation or Storage of Explosives or other Dangerous Articles or Substances, and Combustible Liquids on Board Vessels."

c. U.S. Postal Service Regulation. Title 39, CFR Parts 124 and 125, "Nonmailable Matter" and "Matter Mailable Under Special Rules."

d. International Atomic Energy Agency (IAEA) Safety Series No. 6, "Regulations for the Safe Transport of Radioactive Materials," 1967.

e. AECM 2401, "Physical Protection of Classified Matter and Information."

f. AECM 2405, "Physical Protection of Unclassified Special Nuclear Material."

g. AECM 0230, "Records Disposition."

h. AECM 0530, "Nuclear Criticality Safety."

i. AECM 0560, "Program to Prevent Accidental or Unauthorized Nuclear Explosive Detonations."

j. AECM 5201, "Transportation and Traffic Management" (to be reissued under the title "Transportation of Property").

k. AEC Directory of Radioactive and Fissile Materials Shipping Containers, 1969.

1. International Air Transport Association (IATA) Restricted Article Regulations.

m. U.S. Air Force AFM-4, "Packaging and Handling of Dangerous Materials for Transport by Military Aircraft."

n. Transportation of Explosives Act (18 U.S.C. 832.c).

\section{9-07 NATIONAL EMERGENCY APPLICATION}

During a national emergency, as defined in AECM 0601.04, the provisions of this chapter and appendix will continue in effect. 
PART I

\section{DEFINITIONS AND EXEMPTIONS}

A. DEFINITIONS (as used in this appendix)

1. Carrier means any person engaged in the transportation of passengers or property, as common, contract, or private carrier, or freight forwarder, as those terms are used in the Interstate Commerce Act, as amended, or the U.S. Postal Service.

2. Close Reflection by Water means immediate contact by water of sufficient thickness to reflect a maximum number of neutrons.

3. Containment Vessel means the receptacle on which principal reliance is placed to retain the radioactive material during transport.

4. Fissile Classification means classification of a package or shipment of fissile materials according to the controls needed to provide nuclear criticality safety during transportation as follows:

a. Fissile Class 1. Packages which may be transported in unlimited numbers and in any arrangement and which require no nuclear criticality safety controls during transportation. For purposes of nuclear criticality safety control, a transport index is not assigned to Fissile Class I packages. However, the external radiation levels may require a transport index number. b. Fissile Class II. Packages which may be transported together in any arrangement but in numbers which do not exceed a transport index of 50. For purposes of nuclear criticality safety control, individual packages may have a transport index of not less than 0.1 and not more than 10. However, the external radiation levels may require a higher transport index number but not to exceed 10. Such shipments require no nuclear criticality safety control by the shipper during transportation.

c. Fissile Class III. Shipments of packages which do not meet the requirements of Fissile Classes I or II and which are controlled in transportation by special arrangements between the shipper and the carrier to provide nuclear criticality safety.

5. Fissile Materials means uranium-233, uranium-235, plutonium-238, plutonium-239, and plutonium-241.

6. Large Quantity means a quantity of radioactive material, the aggregate radioactivity of which exceeds that specified in the following table for a transport group as defined in 16. , below:

\begin{tabular}{|c|c|c|c|c|c|c|c|}
\hline $\begin{array}{l}\text { Radionuclide } \\
\text { Identification }\end{array}$ & I & II & III & IV & V & VI-VII & $\begin{array}{c}\text { Special } \\
\text { Form }\end{array}$ \\
\hline Radioactivity & $\begin{array}{c}20 \\
\text { Curies }\end{array}$ & $\begin{array}{c}20 \\
\text { Curies }\end{array}$ & $\begin{array}{c}200 \\
\text { Curies }\end{array}$ & $\begin{array}{c}200 \\
\text { Curies }\end{array}$ & $\begin{array}{c}5,000 \\
\text { Curies }\end{array}$ & $\begin{array}{c}50,000 \\
\text { Cureis }\end{array}$ & $\begin{array}{c}5,000 \\
\text { Curies }\end{array}$ \\
\hline
\end{tabular}

7. Low Specific Activity Material means any of the following:

a. Uranium or thorium ores and physical or chemical concentrates of those ores.

b. Unirradiated natural or depleted uranium or unirradiated natural thorium.

c. Tritium oxide in aqueous solutions, provided the concentration does not exceed 5.0 millicuries per milliliter.

d. Material in which the activity is essentially uniformly distributed and in which the estimated average concentration per gram of contents does not exceed:

(1) 0.0001 millicuries of Group I radionuclides; or

(2) 0.005 millicuries of Group II radionuclides; or

(3) 0.3 millicuries of Group IIl or IV radionuclides.

NOTE: This may include, but is not 
limited to, materials of low radioactivity concentration, such as building rubble, metal, wood, and fabric scrap, glassware, paper and cardboard, solid or liquid plant waste, sludge, and ashes.

e. Nonradioactive objects externally contaminated with radioactive material, provided that the radioactive material is not readily dispersible and the surface contamination, when averaged over an area of one square meter, does not exceed 0.0001 millicuries $(220,000$ disintegrations per minute), per square centimeter of Group I radionuclides or 0.001 millicuries $(2,200,000$ disintegrations per minute) per square centimeter of other radionuclides.

8. Maximum Normal Operating Pressure means the maximum gauge pressure which is expected to develop in the containment vessel under the normal conditions of transport specified in annex 1, below, considered individually.

9. Moderator means a material used to reduce by scattering collisions, and without appreciable capture, the kinetic energy of neutrons.

10. Optimum Interspersed Hydrogenous Moderation means the occurrence of hydrogenous material between containment vessels to such an extent that the maximum nuclear reactivity results.

11. Package means packaging and its radioactive contents.

12. Packaging means one or more receptacles and wrappers and their contents, excluding fissile material and other radioactive material, but including absorbent material, spacing structures, thermal insulation, radiation shielding, devices for cooling and for absorbing mechanical shock, external fittings, neutron moderators, nonfissile neutron absorbers, and other supplementary equipment.

13. Primary Coolant means a gas, liquid, or solid, or combination of them, in contact with the radioactive material, or if the material is in special form, in contact with its capsule, and used to remove decaly heat.
14. Sample Package means a package which is fabricated, packed, and closed to fairly represent the proposed package as it would be presented for transport, simulating the material to be transported, as to weight and physical and chemical form.

15. Special Form means any of the following physical forms of radioactive material of any transport group:

a. The material is in solid form having no dimension less than 0.5 millimeter or at least one dimension greater than 5 millimeters; does not melt, sublime, or ignite in air at a temperature of $1000^{\circ} \mathrm{F}$; will not shatter or crumble if subjected to the percussion test described in annex 4, below; and will not be dissolved or converted into a dispersible form in amounts greater than 0.005 percent by weight if immersed in water at $68^{\circ} \mathrm{F}$ or placed in air at $86^{\circ} \mathrm{F}$ for one week.

b. The material is securely contained in a capsule having no dimension less than 0.5 millimeter or at least one dimension greater than 5 millimeters which (1) will retain its contents if subjected to the tests prescribed in annex $4,(2)$ is constructed of materials which do not melt, sublime, or ignite in air at $1475^{\circ} \mathrm{F}$, and (3) will not be dissolved or converted into a dispersible form in amounts greater than 0.005 percent by weight if immersed for one week in water at $68^{\circ} \mathrm{F}$ or in air at $86^{\circ} \mathrm{F}$.

16. Transport Group means any one of the seven groups in which radionuclides in normal form are classified, according to their toxicity and their relative potential hazard in transport (see annex 3 ).

a. Any radionuclide not specifically listed in one of the groups in annex 3 shall be assigned to one of the groups in accordance with the following table:

\begin{tabular}{|c|c|c|c|}
\hline \multicolumn{4}{|c|}{ Radioactive Half-Life } \\
\hline Radionuclide & $\begin{array}{c}0 \text { to } 1000 \\
\text { days }\end{array}$ & $\begin{array}{c}1000 \text { days to } \\
10^{6} \text { years }\end{array}$ & $\begin{array}{c}\text { Over } 10^{6} \\
\text { Years }\end{array}$ \\
\hline \multicolumn{4}{|c|}{ Atomic Number } \\
\hline $1-81$ & Group III & Group II & Group III \\
\hline \multicolumn{4}{|c|}{ Atomic number } \\
\hline 82 and over & Group I & Group I & Group III \\
\hline
\end{tabular}

Approved: June 14, 1973 
b. For mixtures of radionuclides the following shall apply:

(1) If the identity and respective activity of each radionuclide are known, the permissible activity of each radionuclide shall be such that the sum of the ratios between the total activity for each group to the permissible activity for each group will not be greater than unity.

(2) If the groups of the radionuclides are known, but the amount in each group cannot be reasonably determined, the mixture shall be assigned to the most restrictive group present.

(3) If the identity of all or some of the radionuclides cannot be reasonably determined, each of those unidentified radionuclides shall be considered as belonging to the most restrictive group which cannot be positively excluded.

(4) Mixlures consisting of a single radioactive decay chain where the radionuclides are in the naturally occurring proportions shall be considered as consisting of a single radionuclide. The group and activity shall be that of the first member present in the chain. Exception: If a radionuclide " $x$ " has a half-life longer than that of the first member and an activity greater than that of any other member, including the first, at any time during transportation, the transport group of the nuclide " $x$ " and the activity of the mixture shall be the maximum activity of that nuclide " $\mathrm{x}$ " during transportation.

17. Transport Index means the number placed on a package to designate the degree of control to be exercised by the carrier during transportation. The transport index to be assigned to a package of radioactive material shall be determined by either a. or b., below, whichever is larger. The number expressing the transport index shall be rounded up to the next highest tenth; e.g., 1.01 becomes I.1.

a. The lighest radiation dose rate in millirem per hour at three feet from any accessible external surface of the package.

b. The transport index for each Fissile Class II package is calculated by dividing the number 50 by the number of such Fissile Class II packages which may be transported together as determined under the limitations of part II,I.I. The calculated number shall be rounded up to the first decimal place.

18. Type A Quantity and Type B Quantity mean a quantity of radioactive material, the aggregate radioactivity of which does not exceed that specified in the following table:

Transport Groups

(See I,A.16.)

I $\ldots \ldots \ldots \ldots \ldots$

II $\ldots \ldots \ldots \ldots$

III $\ldots \ldots \ldots \ldots \ldots$

IV $\ldots \ldots \ldots \ldots$

$V \ldots \ldots \ldots \ldots$

VI and VII $\ldots \ldots$.

Special Forum ....

\section{B. EXEMPTIONS}

A shipper is exempt from all requirements of this appendix to the extent that he delivers to a carrier for transport packages each containing not more than a Type A quantity of radioactive material, as defined in A.18, above, which may include one of the following:

1. Not more than 15 grams of fissile material.

2. Thorium or uranium containing not more than 0.72 percent by weight of fissile material.

3. Uranium compounds, other than metal, (e.g., $\mathrm{UF}_{4}, \mathrm{UF}_{6}$, or uranium oxide in bulk form, not pelleted or fabricated into shapes) or aqueous solutions of uranium. in which the total amount of uranium-233 and plutonium present does not exceed 1.0 percent by weight of the uranium-235 content, and the total fissile content does not exceed 1.00 percent by weight of the total uranium content.

4. Homogeneous hydrogenous solutions or mixtures containing not more than:

a. 500 grams of any fissile material. provided the atomic ratio of hydrogen to fissile material is greater than 7600 .

b. 800 grams of uranium-235, provided that the atomic ratio of liydrogen to fissile material greater than 5,200 , and the content of other fissile material is 
Al.('Appendix 05:")

l'in!l

IIot more than I percent by weight of the total uraniun-23.5 content.

c. 500 grams of uranium-2.33 and uranium-235, provided that the atomic ratio of hydrogen to fissile material is greater than 5,200 , and the content of plutonium is not more than 1 percent
SAFETY STANDARDS FOR THE PACKAGING OF FISSII.E ANID OTHER RADIOACTIVE MATERIAL

by weight of the total uranium-23.3 and uranium-2.35 content.

5. Less than 350 grams of fissile material, provided that there is not more than 5 grams of fissile material in any cubic foot within the package. 
A1:(' Appendix 0529

\section{PART II}

\section{PACKAGE STANDARDS}

\section{A. GENERAL STANDARDS FOR ALL PACKAGING}

1. Packaging shall be of such materials and construction that there will be no significant chemical, galvanic, or other reaction among the packaging components or between the packaging components and the package contents.

2. Packaging shall be equipped with a positive closure which will prevent inadvertent opening.

3. Lifting devices for packagings.

a. If there is a system of lifting devices which is a structural part of the packaging, the system shall be capable of supporting three times the weight of the package without generating stress in any material of the packaging in excess of its yield strength.

b. If there is a system of lifting devices which is a structural part only of the lid, the system shall be capable of supporting three times the weight of the lid and any attachments without generating stress in any material of the lid in excess of its yield strength.

c. If there is a structural part of the packaging which could be employed to lift the package and which does not comply with a., above, the part shall be securely covered or locked during transport in such a manner as to prevent its use for that purpose.

d. Each lifting device which is a structural part of the packaging shall be so designed that failure of the device under excessive load would not impair the containment or shielding properties of the packaging.

4. Tiedown devices for packagings

a. If there is a system of tiedown devices which is a structural part of the packaging, the system shall be capable of withstanding, without generating stress in any material of the packaging in excess of its yield strength the following: (1) a static force applied to the center of gravity of the package having a vertical component of two times the weight of the package, (2) a horizontal component along the direction in which the vehicle travels of 10 times the weight of the package, and (3) a horizontal component in the traverse direction of five times the weight of the package.

b. If there is a structural part of the packaging which could be employed to tie the package down and which does not comply with a., above, the part shall be securely covered or locked during transport in such a manner as to prevent its use for that purpose.

c. Each tiedown device which is a structural part of the packaging shall be so designed that failure of the device under excessive load would not impair the ability of the packaging to meet other requirements of this section $A$.

5. Determination of transport indexes for packagings see part $1, A .17$. of this appendix.

\section{B. STRUCTURAL STANDARDS FOR TYPE B AND LARGE QUANTITY PACKAGING}

Packaging used to ship a Type $B$ or a large quantity of radioactive material, as defined in part $1, A .6$ and 18 , above, shall be designed and constructed in compliance with the structural standards of this section. Standards different from those specified in this section may be approved by the manager or other designated official if the controls proposed to be exercised by the shipper are demonstrated to be adequate to assure the safety of the shipment.

1. Load Resistance. Regarded as a simple beam supported at its end along any major axis. packaging shall be capable of withstanding a static load, normal to and uniformly distributed along its length, equal to 5 tmes its fully loaded weight, without generathng stress in any material of the packaging in excess of its yield strength.

2. External Pressure. Packaging shall be adequate to assure that the containment vessel will suffer no loss of contents if subjected to an external pressure of 25 pounds per square-inch gauge.

\section{CRITICALITY STANDARDS FOR FISSILE MATERIAL PACKAGES}

1. A package used for the transport of fissile material shall be so designed and constructed 
and its contents so limited that it would be subcritical if it is assumed that water leaks into the containment vessel; and
a. water moderation of the contents occurs to the most reactive credible extent consistent with the chemical and physical form of its contents; and
b. the containment vessel is fully reflected on all sides by water.

2. A package used for the transport of fissile material shall be so designed and constructed and its contents so limited that it would be subcritical if it is assumed that any contents of the package which are liquid during normal transport leak out of the containment vessel, and that the fissile material is then:
a. in the most reactive credible configuration consistent with the chemical and physical form of the material.
b. moderated by water outside of the containment vessel to the most reactive credible extent.
c. fully reflected on all sides by water.

3. The manager or other designated official may approve exceptions to the requirements of this section where the containment vessel incorporates special design features which would preclude leakage of liquids in spite of any single packaging error, and appropriate measures are taken before each shipment to verify the leak tightness of each containment vessel.

\section{EVALUATION OF A SINGLE PACKAGE}

1. The effect of the transport environment on the safety of any single package of radioactive material shall be evaluated as follows:

a. The ability of a package to withstand conditions likely to occur in normal transport shall be assessed by subjecting a sample packagc or scale model by test of other assessment to the normal conditions of transport as specified in E., below.

b. The effect on a package of conditions likely to occur in an accident shall be assessed by subjecting a sample package or scale model, by test or other assessment, to the hypothetical accident conditions, as specified in $F$, below.

2. Takıng into account controls to be exercised by the shipper, the manager or other designated official may permit the shipment to be evaluated together with or without the transporting vehicle for the purpose of one or more tests.

3. Normal conditions of transport and hypothetical accident conditions different from those specified in E. and F., below, may be approved by the manager or other designated official if the controls proposed to be exercised by the shipper are demonstrated to be adequate to assure the safety of the shipment.

\section{E. STANDARDS FOR NORMAL CONDITIONS OF TRANSPORT FOR A SINGLE PACKAGE}

1. A package used for the shipment of fissile material or more than Type A quantity of radioactive material as defined in part 1, A.6 and 18 , above, shall be so designed and constructed, and its contents so limited that under the normal conditions of transport specified in annex 1 below:

a. there will be no release of radioactive materials from the containment vessel.

b. the effectiveness of the packaging will not be substantially reduced.

c. there will be no mixture of gases or vapors in the package which could, through any credible increases of pressure or an explosion, significantly reduce the effectiveness of the package.

d. radioactive contamination of the liquid or gaseous primary coolant will not exceed $10^{7}$ curies of activity of Group $I$ radionuclides per milliliter, $5 \times 10^{6}$ curies of activity of Group II radionuclides per milliliter; $3 \times 1 \sigma^{4}$ curies of activity of Group III and Group IV radionuclides per milliliter.

e. there will be no loss of coolant or loss of operation of any mechanical cooling device.

2. A package used for the shipment of fissile material shall be designed and constructed, and its contents so limited, that under normal conditions of transport specified in annex 1, considered individually:

a. the package will be subcritical.

b. the geometric form of the package contents would not be substantially altered.

c. there will be no leakage of water into the containment vessel. This requirement need not be met if, in the evaluation of undamaged packages 
under H.1, 1.1.a., or J.1., below, it has been assumed that moderation is present to such an extent as to cause maximum reactivity consistent with the chemical and physical form of the material.

d. there will be no substantial reduction in the effectiveness of the packaging, including:

(1) reduction by more than 5 percent in the total effective volume of the packaging of which nuclear safety is assessed.

(2) reduction by more than 5 percent to the effective spacing on which nuclear safety is assessed between the center of the containment vessel and the outer surface of the packaging.

(3) occurrence of any aperture in the outer surface of the packaging large enough to permit the entry of a 4-inch cube.

3. A package used for the shipment of more than Type A quantity of radioactive material as defined in part I,A.6. and 18., above, shall be so designed and constructed, and its contents so limited, that under the normal conditions of transport specified in annex 1 , considered individually, the containment vessel would not be vented directly to the atmosphere.

\section{F. STANDARDS FOR HYPOTHETICAL ACCIDENT CONDITIONS FOR A SINGLE PACKAGE}

1. A package used for the shipment of more than Type A quantity of radioactive material (see part I,A.6. and 18., above) shall be so designed and constructed, and its contents so limited, that if subjected to the sequence of the hypothetical accident conditions specified in annex 2, it will meet the following conditions:

a. The reduction of shielding would not be sufficient to increase the external radiation dose rate to more than 1000 millirems per hour at three feet from the external surface of the package.

h. No radioactive material would be released from the package except for gases and contaminated coolant containing total radioactivity exceeding neither:
(1) 0.1
percent
of
the total

radioactivity of the package contents; nor

(2) 0.01 curie of Group I radionuclides, 0.5 curie of Group II radionuclides, 10 curies of Group III radionuclides, 10 curies of Group IV radionuclides, and 1000 curies of inert gases irrespective of transport group.

A package need not satisfy the requirements of this paragraph if it contains only low specific activity materials, as defined in part I,A.7, above, and is transported on a motor vehicle, railroad car, aircraft, inland watercraft, or hold or deck of a seagoing vessel assigned for the sole use of the shipper.

2. A package, used for the shipment of fissile material shall be so designed and constructed, and its contents so limited, that if subjected to the sequence of the hypothetical accident conditions specified in annex 2, the package would be subcritical. In determining whether this standard is satisfied, it shall be assumed that:

a. the fissile material is in the most reactive credible configuration consistent with the damaged condition of the package and the chemical and physical form of the contents.

b. water moderation occurs to the most reactive credible extent consistent with the damaged condition of the package and the chemical and physical form of the contents.

c. there is reflection by water on all sides and as close as is consistent with the damaged condition of the package.

\section{G. EVALUATION OF AN ARRAY OF PACKAGES OF FISSILE MATERIAL}

1. The effect of the transport environment on the nuclear criticality safety of an array of packages of fissile material shall be evaluated by subjecting a sample package or a scale model, by test or other assessment, to the hypothetical accident conditions specified in H., I., or J., below, for the proposed fissile class, and by assuming that each package in the array is damaged to the same extent as the sample package or scale model. In the case of a Fissile Class III shipment, the manager or other designated official may, taking into account controls to be exercised 
by the shipper, permit the shipment to be evaluated as a whole rather than as individual packages, and either with or without the transporting vehicle, for the purpose of one or more tests.

2. In determining whether the standards of H.2., I.1.b., and J.2., below, are satisfied, it shall be assumed that:

a. the fissile material is in the most reactive credible configuration consistent with the damaged condition of the package, the chemical and physical form of the contents, and controls exercised over the number of packages to be transported together.

b. water moderation occurs to the most reactive credible extent consistent with the damaged condition of the package and the chemical and physical form of the contents.

\section{H. SPECIFIC STANDARDS FOR A FISSILE CLASS I PACKAGE}

A Fissile Class I package shall be so designed and constructed and its contents so limited that:

1. any number of such undamaged packages would be subcritical in any arrangement, and with optimum interspersed hydrogenous moderation unless there is a greater amount of interspersed moderation in the packaging, in which case that greater amount may be considered.

2. two hundred and fifty such packages would be subcritical in any arrangement, if each package were subjected to the sequence of the hypothetical accident conditions specified in annex 2 , with close reflection by water on all sides of the array and with optimum interspersed moderation unless there is a greater amount of interspersed moderation in packaging, in which case that greater amount may be considered. The condition of the package shall be assumed to be as described in G., above.

\section{SPECIFIC STANDARDS FOR A FISSILE CLASS II PACKAGE}

1. A Fissile Class II package shall be so designed and constructed and its contents so limited, and the number of such packages which may be transported together so limited. that: a. five times that number of such undamaged packages would be subcritical in any arrangement if closely reflected by water.

b. twice that number of such packages would be subcritical in any arrangement if each package were subjected to the sequence of hypothetical accident conditions specified in annex 2, with close reflection by water on all sides of the array and the optimum interspersed hydrogenous moderation, unless there is a greater amount of interspersed moderation in the packaging in which case the greater amount may be considered. The condition of the package shall be assumed to be as described in G., above.

2. The transport index for each Fissile Class II package is calculated by dividing the number 50 by the number of such Fissile Class II packages which may be transported together as determined under the limitations in 1. , above. The calculated number shall be rounded up to the first decimal place.

\section{J. SPECIFIC STANDARDS FOR' A FISSILE CLASS III SHIPMENT}

A package for a Fissile Class III shipment shall be so designed and constructed and its contents and number of packages so limited, that:

1. the undamaged shipment would be subcritical with an identical shipment in contact with it and with the two shipments closely reflected on all sides by water.

2. the shipment would be subcritical if each package were subjected to the hypothetical accident conditions specified in the sequence specified in annex 2 , with close reflection by water on all sides of the array and with the packages in most reactive arrangement and with the most reactive degree of interspersed hydrogenous moderation which would be credible considering the controls to be exercised over the shipment. The condition of the package shall be assumed to be as described in G., above. Hypothetical accident conditions different from those specified in this subparagraph may be approved by the manager or other designated official if the controls proposed to be exercised by the shipper are demonstrated to be adequate to assure the safety of the shipment. 
PART III

\section{QUALITY ASSURANCE PROCEDURES FOR THE FABRICATION, ASSEMBLY, AND TESTING OF OFFSITE SHIPPING CONTAINERS}

\section{A. ESTABLISHMENT AND MAINTENANCE OF PROCEDURES}

1. Each field office shall require its contractors to establish and maintain a quality assurance program tor

a. assure that the requisite standards of quality are met in the fabrication, assembly, and testing of each package.

b. assure that packages in use continue to meet the requisite standards of quality.

\section{B. ELEMENTS OF A QUALITY ASSURANCE PROGRAM}

1. The program shall consist of a formal system of procedural and organizational arrangement which:

a. require that specific responsibilities be assigned to designated units (including those of the vendor, the fabricator, and the contractor) for assuring specified quality at all stages of construction.

b. designate codes, standards, and specifications for materials, equipment, methods of fabrication, testing, and performance.

c. provide for quality control of materials, equipment, and services in instances where these have not already been established by existing standards and specifications.

d. provide, as required by AECM 0504, for at least an annual audit of the $\mathrm{AEC}$ contractors' programs to assess their effectiveness.

e. provide that quality assurance records are maintained in an auditable file during the service life of the container.

f. provide for a method of determining that packagings procured for use from other sources, including AEC contractors and subcontractors or from licensees meet the requirements of AECM $052 \%$.

g. establish acceptance criteria in terms of measurable characteristics and the effects of appropriate tests prescribed in annexes 1,2 , and 4 and as required in part III,C.

h. provide for a program of routine maintenance inspection and. where necessary, retesting to assure that reusable containers continue to meet the applicable design standards.

i. provide for required training, testing, and certification of manufacturing and inspection personnel involved in special processes, such as welding and nondestructive examination, and for the required certification of equiprnent and procedures used in the performance of special processes. 
AFr: Appendix 052\%

\section{PART IV}

\section{OPERATING PROCEDURES}

\section{A. ESTABLISHMENT AND MAINTENANCE OF PROCEDURES}

1. The shipper shall establist and maintain:

a. operating procedures adequate to assure that the determinations and controls required by this appendix are accomplișhed.

b. regular and periodic inspection procedures adequate to assure that the shipper follows the procedures required by a., above.

\section{B. ASSUMPTIONS AS TO UNKNOWN PROPERTIES}

When the isotopic abundance, mass, concentration, degrec of irradiation, degree of moderation, or other pertinent property of fissile material in any package is not known, the shipper shall package the rissile material as if the unknown properties have such credible values as will cause the maximum nuclear reactivity.

\section{PRELIMINARY DETERMINATIONS}

1. Prior to the first use of any packaging for the shipment of more than a Type $A$ quantity of radioactive material or fissile materials, such packaging shall be inspected to ascertain that there are no cracks, pinholes, uncontrolled voids, or other defects which could significantly reduce its effectiveness.

2. Prior to the lirst use of any packaging for the shipment of more llaan a 'Type $A$ quantuty of radioactuve of lissile materials. where the maximum normal operating pressure will exceed 5 pounds per square-inch gauge, the containment vessel sha! be tested to assure that it will not leak at an internal pressure 50 percent higher than the maximum normal operating pressure.

3. Packaging shall be conspicuously and durably marked with its model number. Prior to applying the model number, an inspertion shall be made to determine that the packaging has been fabricated in accordance with the approved design.

\section{ROUTINE DETERMINATIONS}

Prior to each use of a package for shipment of radioactive or fissile material, the shipper shall ascertain that the package with its contents satisfies the applicable requirements of part II including determinations that:

1. the packaging has not been significantly damaged.

2. any moderalors and nonfissile neutron absorbers, if required, are as authorized.

3. the closure of the package and any sealing gaskets are present and are free from defects.

4. any valve through which primary coolant can flow is protected against tampering.

5. The internal gauge pressure of the package will not exceed. during the anticipated period of transport, the maximum normal operating pressure.

6. contamination of the primary coolant will not exceed, during the anticipated period of transport, the limits in part II,E.1.d.

\section{E. RECORDS}

This shipper shall maintain for a period prescribed in appendix 0230, "Records Disposition," a record of each shipment of fissile material and each shipment of amounts of radioactive material greater than Type A quantities as defined in part I,A.6. and 18., in single packages, showing where applicable:

1. identification of the packaging by model number.

2. details of any significant defects in the packaging, with the means employed to repair ihe defects and prevent their recurrence.

i. volume and identilication of coolant.

4. type and quantity of material in each package, and the total quantity in each shipment.

5. for eacl ilem of irradiated fissile material:

J. identification by model number.

b. irradiation and decay history to the extent appropriate to demonstrate that its nuclear and thermal characteristics comply with approved conditions.

c. any ahnormal or unusual condition relevant to radiation safety.

6 . date of the shipment.

?. for Fissile Class III, any special controls exencised.

8. name and address of the transferee.

Approved: June 14, 1973 
9. address to which the shipment was made.

10. results of the determinations required by C'. and D., above.

\section{F. DOCUMENTATION OF TECHNICAL BACKUP SUPPORT FOR SPECIFICATION, CERTIFIED, AND SPECIAL PERMIT PACKAGINGS}

Packagings that have been certified hy the $\Lambda \mathrm{I}$ C as mecting IXOT regulalions and packagngs for which specifications have been publistied by the DOT or a special permil has been issued by the DOT may be used by any shipper having authority to ship radioactive or fissile materials. Therefore, it is essential that technical information and limits pertinent to the construction and use of these packagings be available to all potential users. Accordingly, steps will be taken to implement the following requirements:

1. Field office managers shall require contractors under their jurisdiction to prepare a bound distributable document for each new specification, certified, or special permit, packaging designed, developed, and fabrication by him for offsite shipment of fissile and other radioactive materials. Such a document shall also be required for existing packagings for which the DOT has issued special permits except in those instances of packagings of a highly specialized design and used solely by the originator. Should these specialized packagings be adopted for more general utilization, an appropriate technical document must then be prepared. It shall be the responsibility of the originator or first user to prepare the document for an existing packaging if it is to be used by other AEC field offices and contractors. Obsolete packagings no longer in use and containers used for onsite movement of materials are not subject to these documentation requirements unless they are reactivated, altered, or requested for use in offsite shipments. In such instances the party or paltics requiring reaclivation and/or alterations shall prepare or have propared the appropriate document.

2. Each document shall provide, as a minimum, the following information:

a. a complete physical and technical description of the package.

b. a safety analysis report including considerations for meeting the requirements for packaging and transport safety, nuclear criticality safety, and radiological safety. Pertinent documents in existence as of the date of this revision are acceptable.

c. design and development information including pertinent data, analytical methods, and the results of the prescribed tests.

d. tables, graphs, drawings, pictures, and technical references as required to give a clear treatment of the subject.

3. Each document shall be prepared and submitted to the Technical Information Center in accordance with appendix 3201 , part III,B.2. for reproduction and distribution based upon need. 
ANNEX 1

\section{NORMAL CONDITIONS OF TRANSPORT}

1. Heat-Direct sunlight at an ambient temperature of $130^{\circ} \mathrm{F}$ in still air.

2. Cold-An ambient temperature of $-40^{\circ} \mathrm{F}$ in still air and shade.

3. Pressure-Atmospheric pressure of 0.5 times standard atmospheric pressure.

4. Vibration-Vibration normally incident to transport.

5. Water Spray A water spray sufficiently heavy to keep the entire exposed surface of the package except the bottom continuously wet during a period of 30 minutes.

6. Free Drop-Between $11 / 2$ and $21 / 2$ hours after the conclusion of the water spray test, a free drop through the distance specified below onto a flat essentially unyielding horizontal surface, striking the surface in a position for which maximum damage is expected.

\section{Free Fall Distance}

Package Weight (pounds)

Less than 10,000

10,000 to 20,000

20,000 to 30,000

More than 30,000

Distance (feet)
4
3
2
1

7. Corner Drop-A free drop onto each corner of the package in succession or in the case of a cylindrical package, onto each quarter of each rim, from a height of 1 foot onto a flat essentially unyielding horizontal surface. This test applies only to packages which are constructed primarily of wood or fiberboard, and do not exceed 110 pounds gross weight, and to all Fissile Class II packagings.

8. Penetration-Impact of the hemispherical end of a vertical steel cylinder $11 / 4$ inches in diameter and weighing 13 pounds, dropped from a height of 40 inches onto the exposed surface of the package which is expected to be most vulnerable to puncture.

9. Compression-For packages not exceeding 10,000 pounds in weight, a compressive load equal to either 5 times the weight of the package or 2 pounds per square inch multiplied by the maximum horizontal cross section of the package, whichever is greater. The load shall be applied during a period of 24 hours, uniformly against the top and bottom of the package in the position in which the package would normally be transported.

\section{ANNEX 2}

\section{HYPOTHETICAL ACCIDENT CONDITIONS}

1. Free Drop-A free drop through a distance of 30 feet onto a flat essentially unyielding horizontal surface, striking the surface in a position for which maximum damage is expected.

2. Puncture-A free drop through a distance of 40 inches striking, in a position maximum damage is expected, the rop end of a vertical cylindrical mild steel bar mounted on an essentially unyielding horizontal surface. The bar shall be 6 inches in diameter, with the top horizontal and its edge rounded to a radius of not more than one-quarter inch, and of such a length as to cause maximum damage to the package, but not less than 8 inches long. The long axis of the bar shall be perpendicular to the unyielding horizontal surface.
3. Thermal-Exposure to a thermal test in which the heat input to the package is not less than that which would result from exposure of the whole package to a radiation environment of $1475^{\circ} \mathrm{F}$ for 30 minutes with an emissivity coefficient of 0.9 , assuming the surfaces of the package have an absorption coefficient of 0.8 . The package shall not be cooled artificially until 3 hours after the test period unless it can be shown that the temperature on the inside of the package has begun to fall in less than 3 hours.

4. Water Immersion (fissile material packages only)-Immersion in water to the extent that all portions of the package to be tested are under at least 3 feet of water for a period of not less than 8 hours. 
ANNEX 3

\section{TRANSPORT GROUPING OF RADIONUCLIDES}

\begin{tabular}{|c|c|c|c|c|c|}
\hline Element' & Radionuclides $^{2}$ & Group & Element' & Radionuclides $^{2}$ & Group \\
\hline \multirow[t]{2}{*}{ Actinium (89) } & Ac 227 & I & Copper (29) & $\mathrm{Cu} 64$ & IV \\
\hline & Ac 228 & 1 & Curium (96) & $\mathrm{Cm} 242$ & I \\
\hline \multirow[t]{2}{*}{ Americium (95) } & Am 241 & I & & $\mathrm{Cm} 243$ & I \\
\hline & Am 243 & 1 & & Cm 244 & I \\
\hline \multirow[t]{3}{*}{ Antimony (51) } & Sb 122 & IV & & ( $\mathrm{m} 245$ & I \\
\hline & Sb 124 & III & & ('m 246 & I \\
\hline & Sb 125 & 1111 & Dysprosium (66) & Dy 154 & III \\
\hline \multirow[t]{3}{*}{ Argon (18) } & $\operatorname{Ar} 37$ & VI & & Dy 165 & IV \\
\hline & Ar 41 & II & & Dy 166 & IV \\
\hline & Ar $41^{3}$ (uncompressed) & $\mathrm{V}$ & Erbium (68) & Er 169 & IV \\
\hline \multirow[t]{4}{*}{ Arsenic (33) } & As 73 & IV & & Er 171 & IV \\
\hline & As 74 & IV & Europium (63) & Eu 150 & III \\
\hline & As 76 & IV & & Eu $152 \mathrm{~m}$ & IV \\
\hline & As 77 & IV & & Eu 152 & III \\
\hline Astatine (85) & At 211 & III & & Eu 154 & II \\
\hline \multirow[t]{3}{*}{ Barium (56) } & Ba 131 & IV & & Eu 155 & IV \\
\hline & Ba 133 & II & Fluorine (9) & F 18 & IV \\
\hline & Ba 140 & III & Gadolinium (64) & Gd 153 & IV \\
\hline Berkelium (97) & Bk 249 & I & & Gd 159 & IV \\
\hline Beryllium (4) & Be 7 & IV & Gallium (31) & $\mathrm{Ga} 67$ & III \\
\hline \multirow[t]{4}{*}{ Bismuth (83) } & Bi 206 & IV & & $\mathrm{Ga} 72$ & IV \\
\hline & Bi 207 & III & Germanium (32) & $\mathrm{Ge} 71$ & IV \\
\hline & Bi 210 & II & Gold (79) & Au 193 & III \\
\hline & Bi 212 & III & & Au 194 & III \\
\hline Bromine (35) & Br 82 & IV & & $\mathrm{Au} 195$ & III \\
\hline \multirow{3}{*}{ Cadmium (48) } & $\mathrm{Cd} 109$ & IV & & Au 196 & IV \\
\hline & $\mathrm{Cd} 115 \mathrm{~m}$ & III & & $\mathrm{Au} 198$ & IV \\
\hline & Cd 115 & IV & & Au 199 & IV \\
\hline \multirow[t]{2}{*}{ Calcium (20) } & Ca 45 & IV & Hafnium (72) & Hf 181 & IV \\
\hline & $\mathrm{Ca} 47$ & IV & Holmium (67) & Ho 166 & IV \\
\hline \multirow[t]{3}{*}{ Californium (98) } & Cf 249 & I & Hydrogen (1) & H 3 (see tritium) & \\
\hline & Cf 250 & I & Indium (49) & In $11.3 \mathrm{~m}$ & IV \\
\hline & Cf 252 & 1 & & $\ln 114 \mathrm{~m}$ & III \\
\hline Carbon (6) & C 14 & IV & & In $115 \mathrm{~m}$ & IV \\
\hline \multirow[t]{3}{*}{ Cerium (58) } & Ce 141 & IV & & $\ln 115$ & IV \\
\hline & Ce 143 & IV & lodine (53) & I 124 & III \\
\hline & Ce 144 & III & & 1125 & III \\
\hline \multirow[t]{6}{*}{ Cesium (55) } & Cs 131 & IV & & I 126 & III \\
\hline & Cs $134 \mathrm{~m}$ & III & & 1129 & III \\
\hline & Cs 134 & III & & I 131 & III \\
\hline & Cs 135 & IV & & 1132 & IV \\
\hline & Cs 136 & IV & & I 133 & III \\
\hline & Cs 137 & III & & I 134 & IV \\
\hline \multirow[t]{2}{*}{ Chlorine (17) } & $\mathrm{Cl} 36$ & III & & I 135 & IV \\
\hline & Cl 38 & IV & Iridium (77) & Ir 190 & IV \\
\hline Chormium (24) & Cr 51 & IV & & Ir 192 & III \\
\hline \multirow{5}{*}{ Cobalt (27) } & Co 56 & III & & Ir 194 & IV \\
\hline & $\operatorname{Co} 57$ & IV & Iron (26) & Fe 55 & IV \\
\hline & Co $58 \mathrm{~m}$ & IV & & Fe 59 & IV \\
\hline & Co 58 & IV & Krypton (36) & $\mathrm{Kr} 85 \mathrm{~m}$ & III \\
\hline & Co 60 & III & & $\mathrm{Kr} 85^{3}$ (uncompressed) & $\mathrm{V}$ \\
\hline
\end{tabular}


AEC Appendix 0529

SAFETY STANDARDS FOR THE PACKAGING OF

Annex 3

FISSILE AND OTHER RADIOACTIVE MATERIAL

\begin{tabular}{|c|c|c|c|c|c|}
\hline \multirow[t]{5}{*}{ Element' } & Radionuctides $^{2}$ & Group & Element ${ }^{t}$ & Radionuclides ${ }^{2}$ & Group \\
\hline & $\mathrm{Kr} 85$ & III & Protactinium (91) & $\mathrm{Pa} 230$ & I \\
\hline & $\mathrm{Kr} 85^{3}$ (uncompressed) & VI & & $\mathrm{Pa} 231$ & i \\
\hline & Kr 87 & II & & Pa 233 & II \\
\hline & $\mathrm{Kr} 87^{3}$ (uncompressed) & $\mathbf{V}$ & Radium (88) & $\operatorname{Ra} 223$ & II \\
\hline 1 anthanum (57) & La 140 & IV & & $\operatorname{Ra} 224$ & in \\
\hline \multirow[t]{3}{*}{ Lead (82) } & $\mathrm{Pb} 203$ & IV & & $\operatorname{Ra} 226$ & I \\
\hline & $\mathrm{Ph} 210$ & ll & & $\operatorname{Ra} 228$ & l \\
\hline & $\mathrm{Pb} 212$ & II & Radon (86) & $\operatorname{Rn} 220$ & IV \\
\hline \multirow{2}{*}{ Lutetium (71) } & Lu 172 & III & & $\operatorname{Rn} 222$ & II \\
\hline & Lu 177 & IV & Rhenium (75) & $\operatorname{Re} 183$ & IV \\
\hline \multirow{4}{*}{$\begin{array}{l}\text { Magnesium (J 2) } \\
\text { Manganese (25) }\end{array}$} & $\mathrm{Mg} 28$ & IIJ & & $\operatorname{Re} 186$ & IV \\
\hline & Mn 52 & IV & & $\operatorname{Re} 187$ & IV \\
\hline & Mn 54 & iv & & $\operatorname{Re} 188$ & IV \\
\hline & Mn 56 & IV & & Re Natural & IV \\
\hline \multirow[t]{3}{*}{ Mercury $(80)$} & $\mathrm{Hg} 197 \mathrm{~m}$ & IV & Rhodium (45) & Rh $103 \mathrm{~m}$ & IV \\
\hline & $\mathrm{Hg} 197$ & IV & & Rh 105 & IV \\
\hline & $\mathrm{Hg} 203$ & iv & Rubidium (37) & $\mathbf{R b} 86$ & IV \\
\hline \multicolumn{2}{|c|}{ Mixed Fission Products MFP } & II & & Rb 87 & IV \\
\hline Molybdenum (42) & Mo & iv & & $\mathrm{Rb}$ Natural & IV \\
\hline \multirow{2}{*}{ Noodymium (60) } & Nd 147 & iv & Ruthenium (44) & Ru 97 & IV \\
\hline & $\mathrm{Nd} 149$ & IV & & Ru 103 & IV \\
\hline \multirow[t]{2}{*}{ Nept unium (93) } & Np 2.37 & I & & Ru 105 & IV \\
\hline & Np 239 & I & & Ru 106 & III \\
\hline \multirow[t]{4}{*}{ Nickel (28) } & Ni 56 & III & Samarium (62) & Sm 145 & III \\
\hline & Ni 59 & IV & & Sm 147 & III \\
\hline & $\mathrm{Ni} 63$ & IV & & $\operatorname{Sm} 151$ & IV \\
\hline & $\mathrm{Ni} 65$ & IV & & Sm 153 & IV \\
\hline \multirow[t]{3}{*}{ Niohium (41) } & $\mathrm{Nb} 93 \mathrm{~m}$ & IV & Scandium (21) & Sc 46 & III \\
\hline & $\mathrm{Nb} 95$ & IV & & Sc 47 & IV \\
\hline & $\mathrm{Nb} 97$ & IV & & Sc 48 & IV \\
\hline \multirow[t]{4}{*}{ Osmium (76) } & Os 185 & IV & Selenium (34) & Se 75 & IV \\
\hline & Os $191 \mathrm{~m}$ & IV & Silicon (14) & Si 31 & IV \\
\hline & Os 191 & IV & Silver (47) & Ag 105 & IV \\
\hline & Os 193 & IV & & $\mathrm{Ag} 110 \mathrm{~m}$ & III \\
\hline \multirow[t]{2}{*}{ Palladium (46) } & Pd 10.3 & IV & & $\mathrm{Ag} 111$ & IV \\
\hline & Pd 109 & IV & Sodium (11) & $\mathrm{Na} 22$ & III \\
\hline Phosphorus (15) & P.32 & IV & & Na 24 & IV \\
\hline \multirow[t]{5}{*}{ Platinum (78) } & Pt 191 & IV & Strontium (38) & $\mathrm{Sr} 85 \mathrm{~m}$ & IV \\
\hline & Pt 193 & IV & & Sr 85 & IV \\
\hline & Pt $19.3 \mathrm{~m}$ & IV & & Sr 89 & III \\
\hline & Pt $197 \mathrm{~m}$ & IV & & Sr 90 & II \\
\hline & Pt 197 & IV & & Sr 91 & III \\
\hline \multirow[t]{5}{*}{ Plutonium (94) } & $\mathrm{Pu} 238$ (F) & I & & Sr 92 & IV \\
\hline & Pu $239(F)$ & I & Sulphur (16) & S 35 & IV \\
\hline & Pu 240 & i & Tantalum (73) & Ta 182 & III \\
\hline & Pu 241 (F) & I & Technetium (43) & Tc $96 \mathrm{~m}$ & IV \\
\hline & Pu 242 & I & & Tc 96 & IV \\
\hline \multirow{3}{*}{$\begin{array}{l}\text { Polonium (84) } \\
\text { Potassium (19) }\end{array}$} & Po 210 & I & & Tc $97 \mathrm{~m}$ & IV \\
\hline & K 42 & IV & & Tc 97 & IV \\
\hline & K 43 & III & & Tc $99 \mathrm{~m}$ & IV \\
\hline \multirow[t]{2}{*}{ Praseodymium (59) } & $\operatorname{Pr} 142$ & IV & & Tc 99 & IV \\
\hline & $\operatorname{Pr} 143$ & IV & Tellurium (52) & $\mathrm{Te} 125 \mathrm{~m}$ & IV \\
\hline \multirow[t]{2}{*}{ Promethium $(61)$} & $\operatorname{Pm} 147$ & IV & & Te $127 \mathrm{~m}$ & IV \\
\hline & Pm 149 & IV & & $\mathrm{Te} 127$ & IV \\
\hline
\end{tabular}

Approved: June 14, 1973 


\begin{tabular}{|c|c|c|c|c|c|}
\hline \multirow[t]{5}{*}{ Element ${ }^{1}$} & Radionuclides $^{2}$ & Group & Element' & Radionuclides ${ }^{2}$ & Group \\
\hline & $\mathrm{Te} 129 \mathrm{~m}$ & III & Uranium (92) & U 230 & II \\
\hline & $\operatorname{Te} 129$ & IV & & U 232 & I \\
\hline & $\mathrm{Te} 131 \mathrm{~m}$ & III & & U 233 (F) & II \\
\hline & $\mathrm{Te} 132$ & IV & & U 234 & II \\
\hline Terbium (65) & Tb 160 & III & & U235(H) & I:̈ \\
\hline \multirow[t]{4}{*}{ Thallium (81) } & T1 200 & IV & & U 236 & II \\
\hline & Tl 201 & IV & & U 238 & III \\
\hline & T1 202 & IV & & U Natural & III \\
\hline & T1 204 & III & & U Enriched (F) & IUI \\
\hline \multirow[t]{7}{*}{ Thorium (90) } & Th 227 & II & & U Depleted & III \\
\hline & Th 228 & I & Vandium (23) & V 48 & IV \\
\hline & Th 230 & I & & v 49 & III \\
\hline & Th 231 & 1 & Xenon (54) & Xe 125 & III \\
\hline & Th 232 & III & & $\mathrm{Xe} 131 \mathrm{n}$ & III \\
\hline & Th 234 & II & & Xe $131^{3} \mathrm{~m}$ (uncompressed) & d) $\mathrm{V}$ \\
\hline & Th Natural & IIl & & $\mathrm{Xe} 133$ & III \\
\hline \multirow[t]{3}{*}{ Thulium (69) } & $\operatorname{Tm} 168$ & III & & Xe $133^{3}$ (uncompressed) & VI \\
\hline & $\operatorname{Tm} 170$ & III & & $\mathrm{Xe} 135$ & II \\
\hline & $\operatorname{Tm} 171$ & IV & & Xe $135^{3}$ (uncompressed) & $\mathrm{V}$ \\
\hline \multirow[t]{4}{*}{$\operatorname{Tin}(50)$} & Sn 113 & IV & Ytterbium (70) & Yb 175 & IV \\
\hline & Sn 117 & III & Yttrium (39) & Y 88 & III \\
\hline & Sn 121 & III & & Y90 & IV \\
\hline & Sn 125 & IV & & Y91 m & nII \\
\hline \multirow[t]{5}{*}{ Tritium (1) } & H 3 & IV & & Y91 & III \\
\hline & H 3 (as gas, as & VII & & Y92 & IV \\
\hline & luminous paint & & & Y 93 & IV \\
\hline & or absorbed on & & Zinc (30) & $\operatorname{Zn} 65$ & N \\
\hline & solid material) & IV & & $\begin{array}{l}\operatorname{Zn} 69 \mathrm{~m} \\
\operatorname{Zn} 69\end{array}$ & Jy \\
\hline \multirow{3}{*}{ Tungsten (74) } & w 181 & iv & & $\operatorname{Ln} 69$ & iv \\
\hline & W 185 & IV & Zirconium (40) & $\operatorname{Zr} 93$ & m \\
\hline & W 187 & IV & & $\begin{array}{l}\operatorname{Zr} 95 \\
70_{07}\end{array}$ & li! \\
\hline
\end{tabular}

1 Atomic Number shown in parentheses.

${ }^{2}$ Atomic weight shown after the radionuclide symbol.

'Uncompressed means at a pressure not exceeding one atmosphere.

m Metastable state.

(F) Fissile Material.

\section{ANNEX 4}

\section{TESTS FOR SPECIAL FORM MATERIAL}

1. Free Drop-A free drop through a distance of 30 feet onio a flat issentially unyielding horizontal surface, striking the surface in such a position as to suffer maximum damage.

2. Percussion-Impact of the flat circular end of a 1 -inch diameter steel rod weighing 3 pounds, dropped through a distance of 40 inches. The sapsule or material shall be placed on a sheet of lead, of hardness number 3.5 to 4.5 on the Vickers scale, and not more than 1 -inch thick, supported by a smooth essentially unyielding surface.

3. Heating-Heating in air to a temperature of $1475^{\circ} \mathrm{F}$ and remaining at that temperature for a period of 10 minutes.

4. Immersion-Immersion for 24 hours in water at room temperature. The water shall be at $\mathrm{pH} 6-\mathrm{pH}$ 8, with a maximum conductivity of 10 micromhos per centimeter. 